\title{
Cellular Prion Protein (PrPC): Identification and Characterization of Novel Interacting Partners
}

\author{
Dissertation \\ zur Erlangung des Doktorgrades \\ der Mathematisch-Naturwissenschaftlichen Fakultäten \\ der Georg-August-Universität zu Göttingen
}

vorgelegt von

Saima Zafar

aus Lahore, Pakistan 
D7

Referent: Prof. Dr.Uwe Groß

Korreferent: Prof. Dr. Nils Brose

Tag der mündlichen Prüfung: 17-01-2011 
I hereby declare that the $\mathrm{PhD}$ thesis entitled "Cellular Prion Protein $\left(\operatorname{PrP}^{\mathrm{C}}\right)$ : Identification and Characterization of Novel Interacting Partners" was written independently and with no other sources and aids than those quoted.

Saima Zafar 
Dedicated to Hazrat Muhammad (Peace Be Upon Him) 


\section{Table of Contents}

Abbreviations ...................................................................................... 1

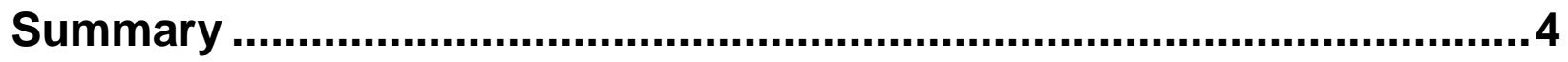

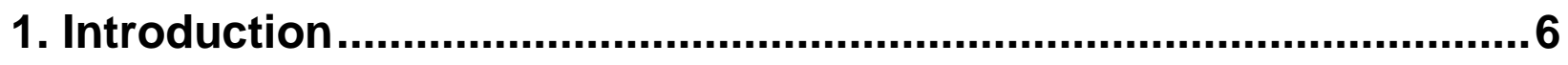

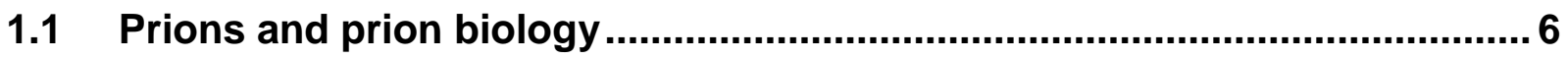

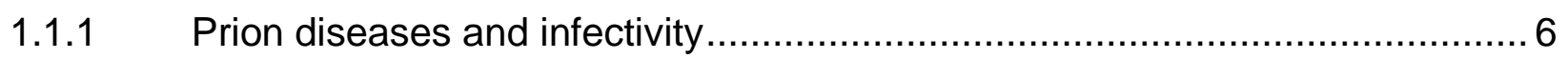

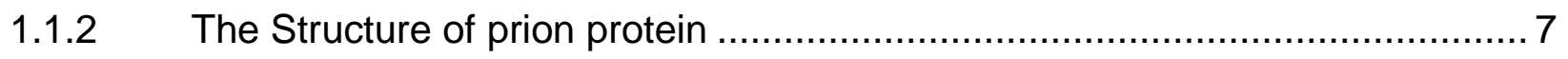

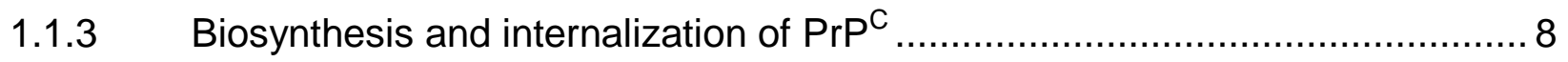

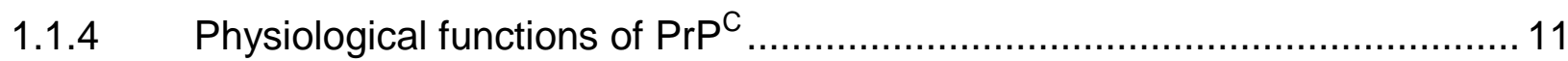

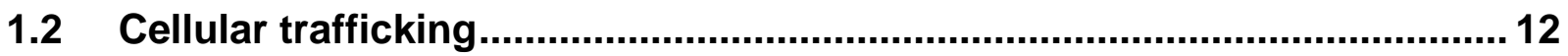

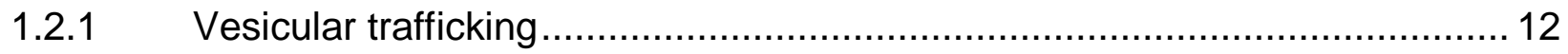

1.2.2 RAS superfamily of monomeric GTP-binding proteins .............................. 12

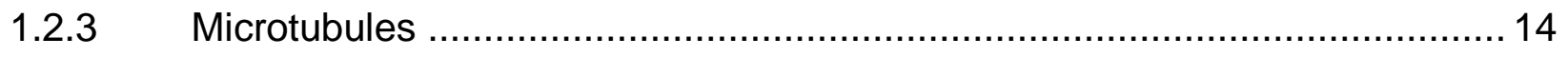

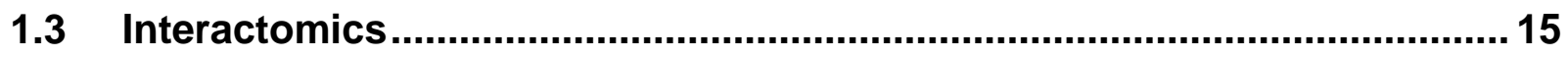

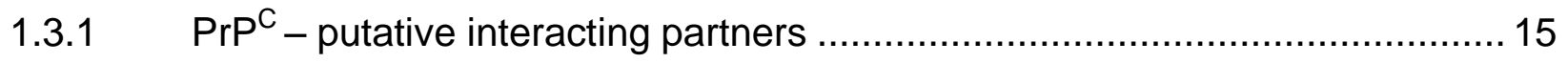

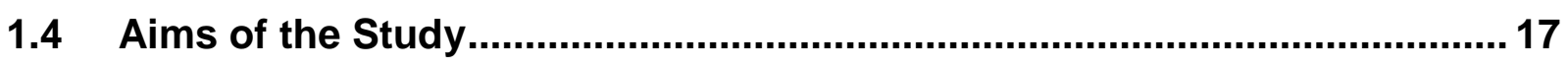

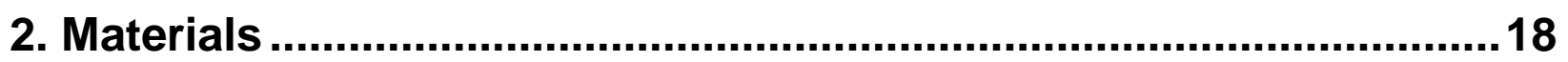

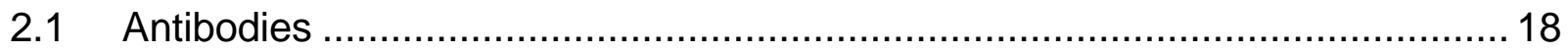

2.2 Antibiotics, enzymes and standards ……….......................................... 19

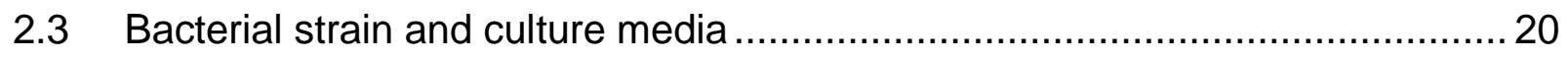

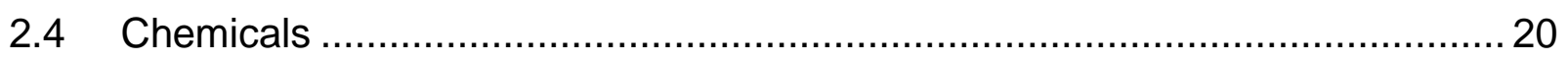

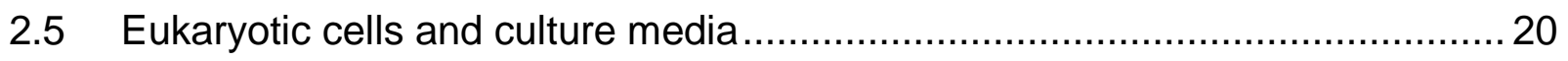

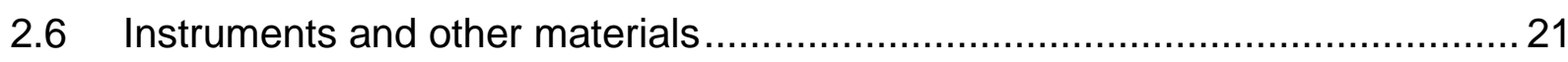

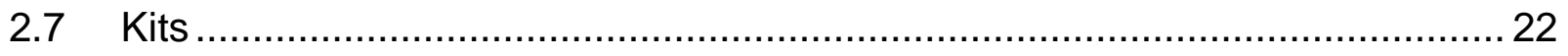

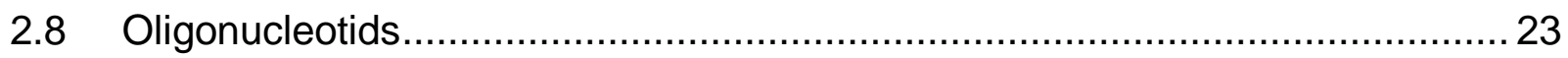

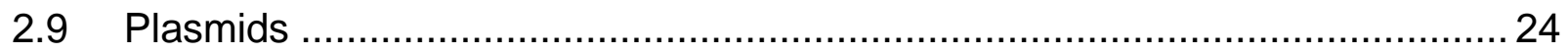

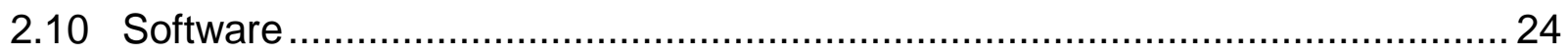




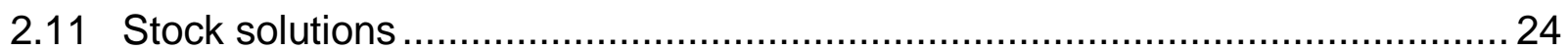

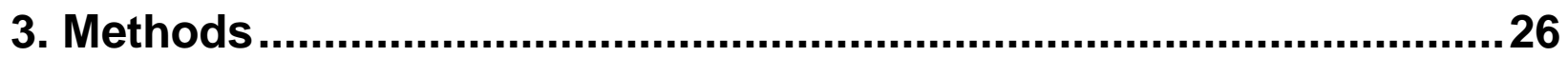

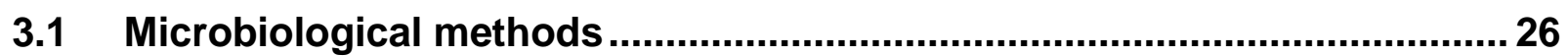

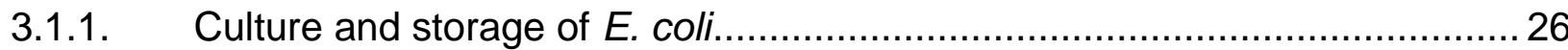

3.1.2. Preparation of electrocompetent E. coli cells ........................................ 26

3.1.3. Transformation of electrocompetent E. coli with plasmid DNA .....................26

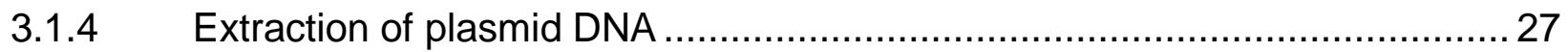

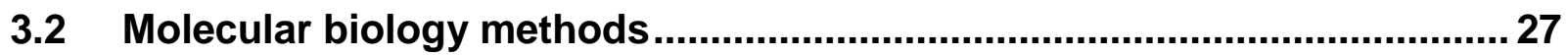

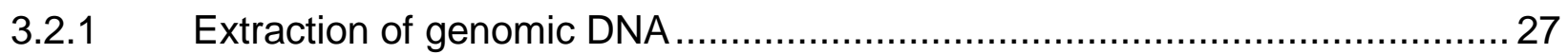

3.2.2 Combinatorial cloning procedures....................................................... 28

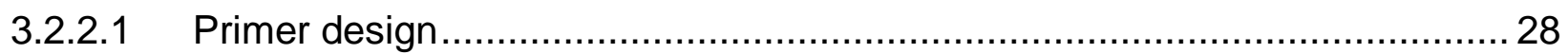

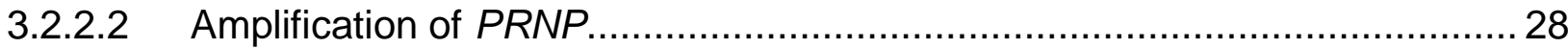

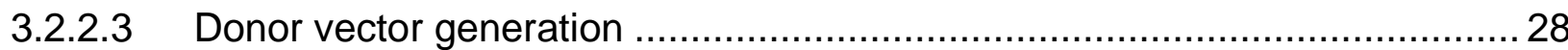

3.2.2.4 Mammalian expression vector generation ………................................... 29

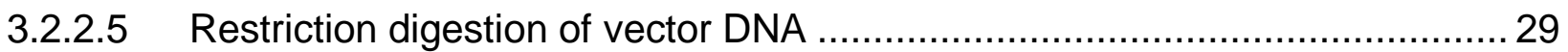

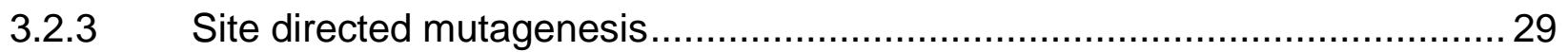

3.2.4 DNA agarose gel electrophoresis ......................................................... 30

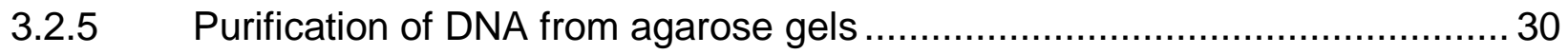

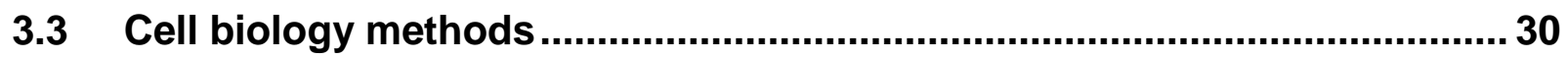

3.3.1 Cryopreservation and thawing of eukaryotic cells ...................................... 30

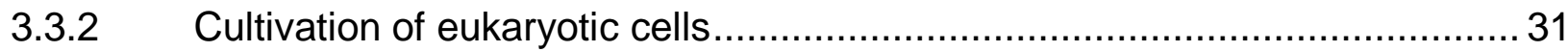

3.3.3 Liposome-mediated transient transfection .............................................. 31

3.3.4 Small interference RNAi treatment........................................................ 31

3.3.5 Immunocytochemical and quantification analysis ...................................... 32

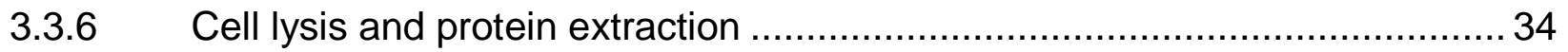

3.3.7 Determination of protein concentration .................................................. 34

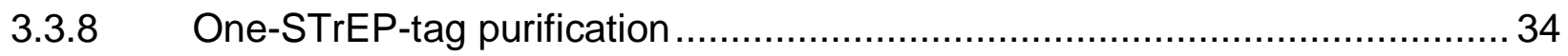

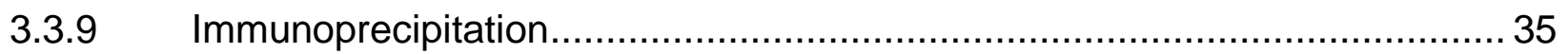


3.3.10 SDS-PAGE 35

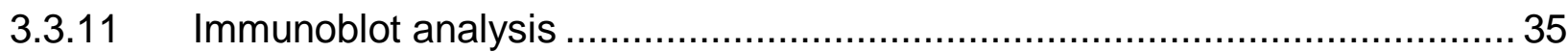

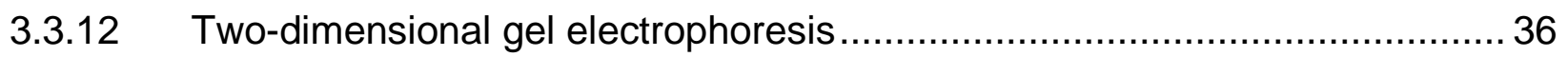

3.3.13 Protein/peptide sequence identification by LC/MS-MS ............................... 37

3.3.13.1 In-gel digestion and preparation of proteins and proteolytic fragments ......... 37

3.3.13.2 Identification of protein/peptide sequence analysis .................................... 38

3.3.14 Enzyme-linked immunosorbent assay (ELISA) .......................................... 38

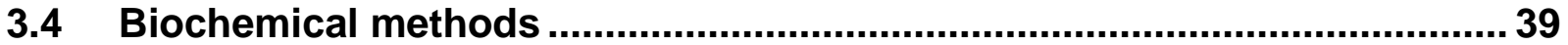

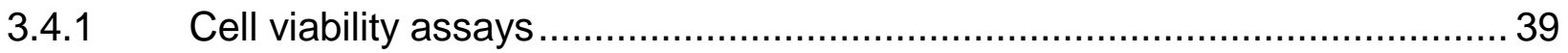

3.4.2 Caspase-3 activity assay ................................................................. 40

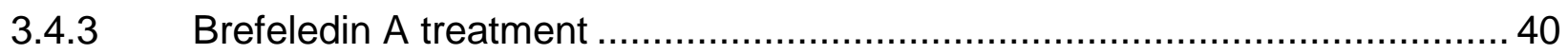

3.4.4 Microtubule disruption treatment ....................................................... 40

3.4.5 Protease K degradation assay ............................................................. 40

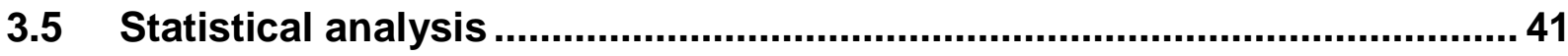

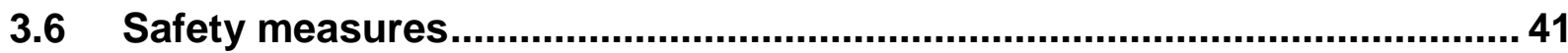

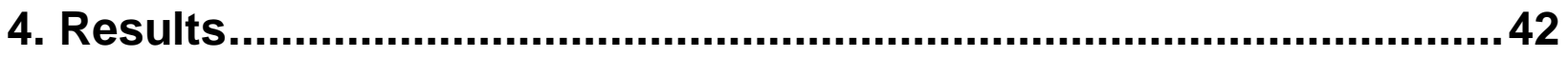

4.1 Generation and expression of C-terminus One-STrEP-tag-PrP ${ }^{C} \ldots \ldots \ldots \ldots . . . . . . . .42$

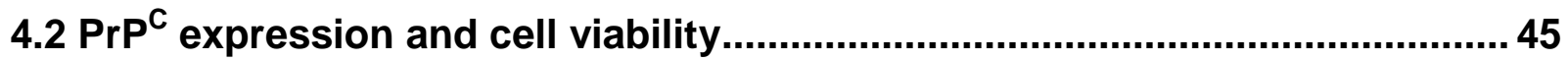

4.2.1 $\mathrm{PrP}^{\mathrm{C}}$ expression and cell viability in HpL3-4 and SH-SY5Y cells .................. 45

4.2.3 Caspase-3 activity in $\operatorname{PrP}^{\mathrm{C}}$ expressing cells ................................................. 47

4.3 Purification and identification of $\operatorname{PrP}^{\mathrm{C}}$ interacting proteins ........................... 49

4.3.1 C-terminus One-STrEP-tag $\operatorname{PrP}^{C}$ affinity purification of $\operatorname{PrP}^{C}$ complex.......... 49

4.2.2 Binding of C-terminus One-STrEP-tag $\mathrm{PrP}^{\mathrm{C}}$ by interacting partners ............. 56

4.3 Characterization of interacting partners …..................................................... 57

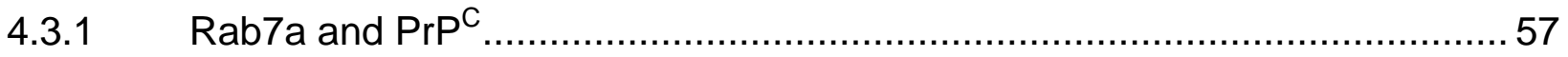

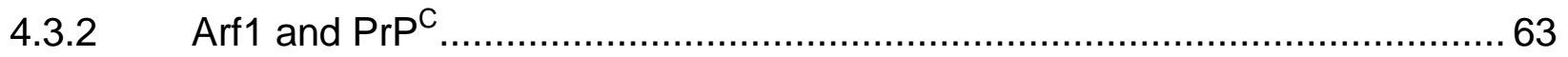

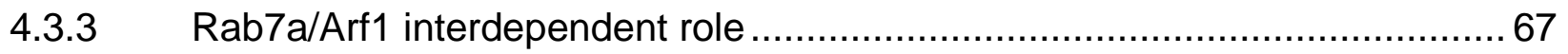

4.3.4 Microtubule fate in $\operatorname{PrP}^{\mathrm{C}}$, Rab7a and Arf1 internalization .............................68 


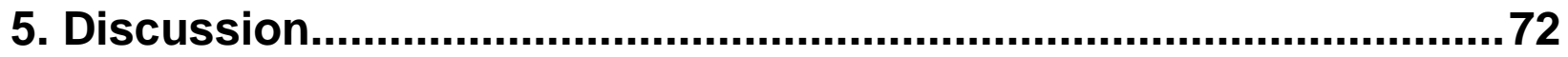

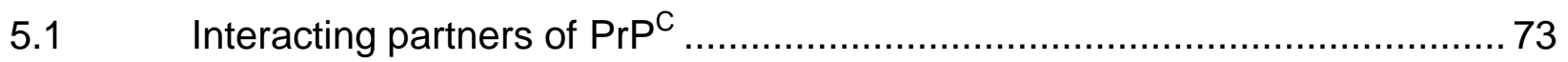

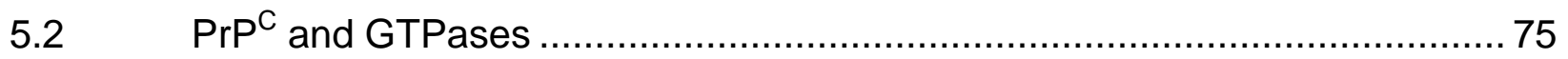

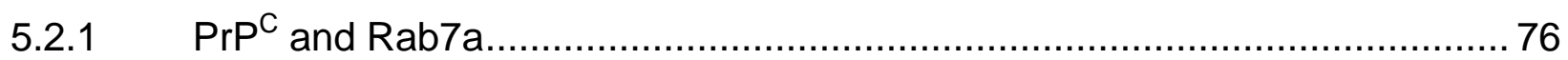

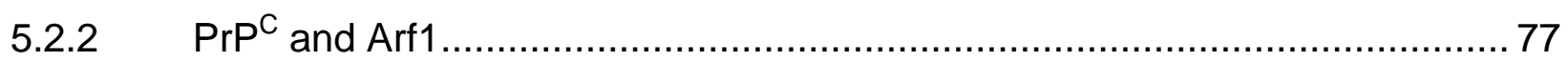

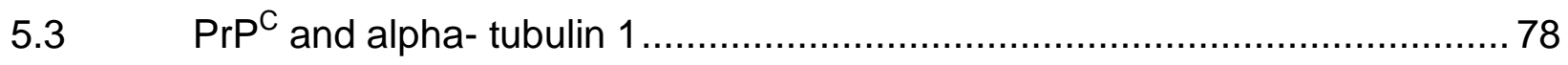

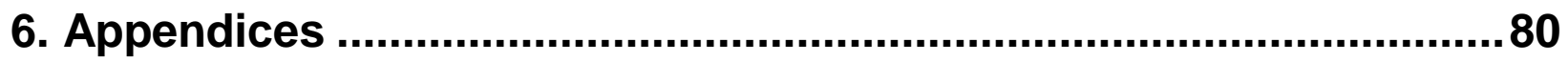

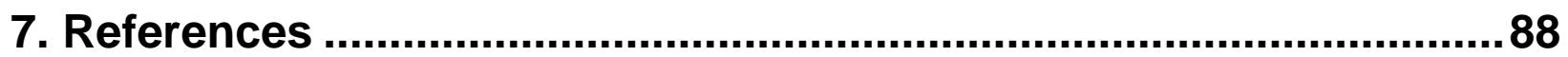

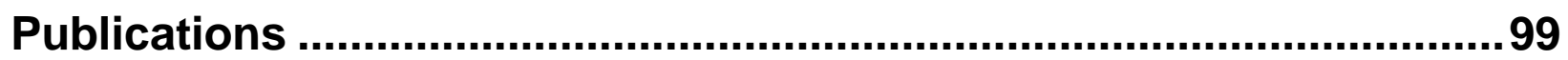

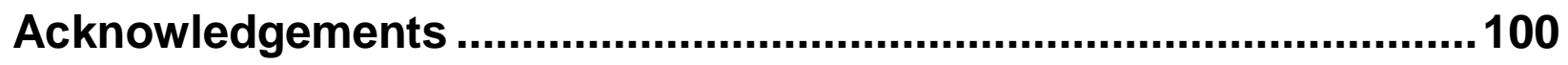

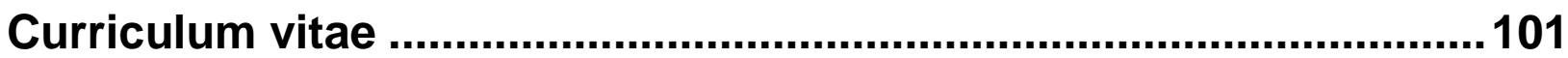




\section{List of Figures}

Figure 1 The structural features of the cellular prion protein. ….................................... 8

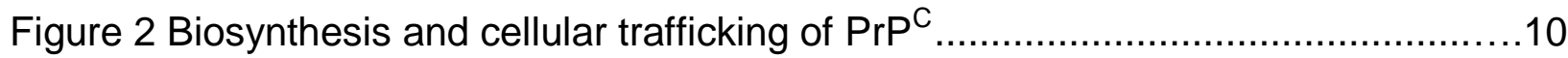

Figure 3 Rab proteins and vesicular trafficking. .................................................... 14

Figure 4 C-terminus One-STrEP-tag PrP ${ }^{C}$ plasmid................................................ 43

Figure $5 \mathrm{PrP}^{\mathrm{C}}$ expression in HpL3-4 cells after transient transfection. ........................ 44

Figure $6 \mathrm{PrP}^{\mathrm{C}}$ localization in HpL3-4 cells after transient transfection......................... 45

Figure 7 Viability of transient $\operatorname{PrP}^{C}$ expressing HpL3-4 cells. ...................................... 46

Figure 8 Viability of stable $\operatorname{PrP}^{\mathrm{C}}$ expressing SH-SY5Y cells......................................46

Figure 9 Caspase-3 activity in HpL3-4 and SH-SY5Y cells ...................................... 48

Figure 10 Identification of $\mathrm{PrP}^{\mathrm{C}}$ multiprotein complex from HpL3-4 cells purification by $\mathrm{C}$ -

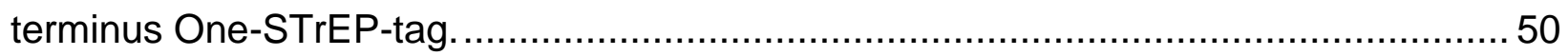

Figure 11 The functional categorization of identified interacting partners of $\operatorname{PrP}^{C} \ldots \ldots . .55$

Figure $12 \mathrm{PrP}^{\mathrm{C}}$ interacts with Rab7a, Arf1 and alpha-tubulin 1................................56

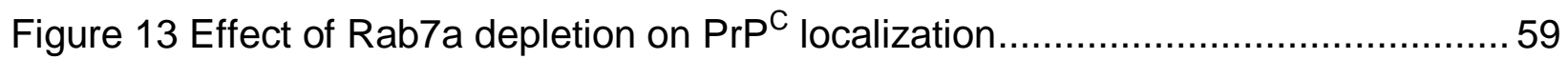

Figure 14 Effect of Rab7a depletion on $\operatorname{PrP}^{\mathrm{C}}$, Arf1 and alpha-tubulin 1 expression. ......61

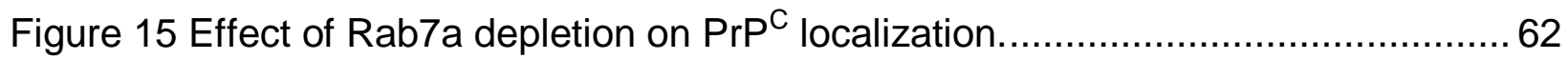

Figure 16 Figure 16 PK-digestion of $\operatorname{PrP}^{\mathrm{C}}$ under Rab7a knockdown HpL3-4 cells........ 63

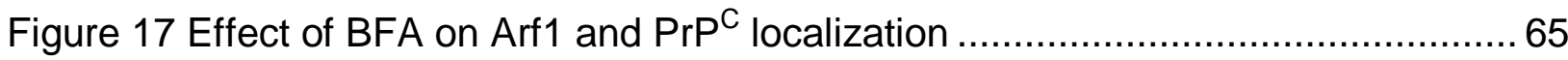

Figure 18 Effect of BFA treatment on $\mathrm{PrP}^{\mathrm{C}}$, Rab7a, Arf1 and alpha-tubulin 1

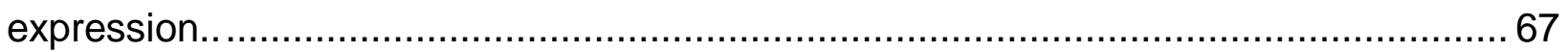

Figure 19 Effect of nocodazole on alpha-tubulin 1 and $\operatorname{PrP}^{\mathrm{C}}$ Iocalization.....................69 Figure 20 Effect of nocodazole on $\operatorname{PrP}^{\mathrm{C}}$, Rab7a, Arf1 and alpha tubulin 1 expression.. 71

Figure 21 Influence of Rab7a depletion on $\mathrm{PrP}^{\mathrm{C}}$ expression and localization ................77 


\section{List of Tables}

Table 1 List of antibodies and their application in present study ...................... 18

Table 2 List of antibiotics, enzymes and standards............................... 19

Table 3 List of bacterial strains and culture media................................ 20

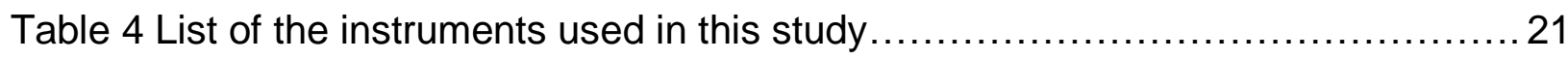

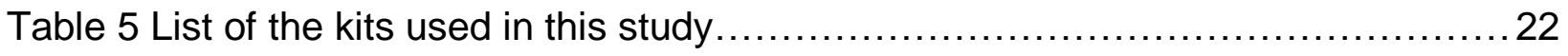

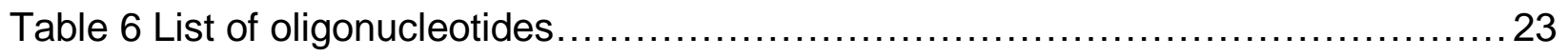

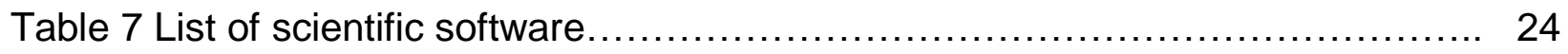

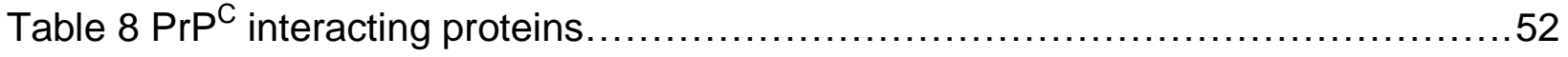

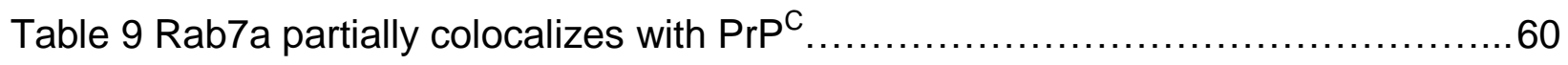

Table 10 Rab9 colocalizes with $\mathrm{PrP}^{\mathrm{C}}$ in Rab7a depleted HpL3-4 cells....................62

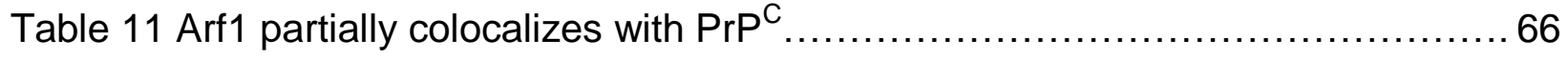

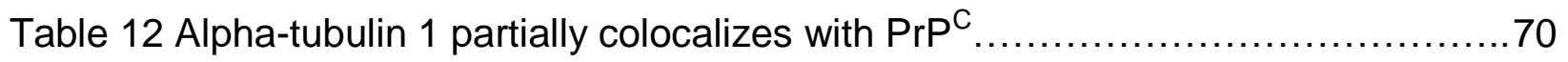




\section{Abbreviations}

\begin{tabular}{|c|c|}
\hline${ }^{\circ} \mathrm{C}$ & Celsius \\
\hline$\mu \mathrm{l}$ & Micro liter \\
\hline$\mu \mathrm{m}$ & Micro meter \\
\hline 2-DE & Two-dimensional gel electrophoresis \\
\hline aa & Amino acid \\
\hline$A D$ & Alzheimer's disease \\
\hline Arf1 & ADP-ribosylation factor 1 \\
\hline ATP & Adenosine triphosphate \\
\hline BFA & Brefeldin A \\
\hline bp & Base pair \\
\hline BPB & Bromophenol blue \\
\hline BSA & Bovine serum albumin \\
\hline BSE & Bovine spongiform encephalopathy \\
\hline cDNA & Complementary deoxyribonucleic acid \\
\hline CSF & Cerebrospinal fluid \\
\hline $\mathrm{ddH}_{2} \mathrm{O}$ & Double distilled water \\
\hline DMEM & Dulbecco's Modified Eagle Medium \\
\hline DMSO & Dimethylsulfoxide \\
\hline EDTA & Ethylene diamine tetra acetic acid \\
\hline ELISA & Enzyme-linked immunosorbent assay \\
\hline ER & Endoplasmic reticulum \\
\hline ERAD & Endoplasmic reticulum associated degradation \\
\hline ERGIC & ER-Golgi intermediate compartment \\
\hline ESI-QTOF-MS & ElectroSpray Ionisation-Time-of-Flight Mass Spectrometry \\
\hline FCS & Fetal calf serum \\
\hline For & Forward \\
\hline $\mathrm{H}$ & Hour \\
\hline HEK-293 & Human Embryonic Kidney 293 cell line \\
\hline HpL3-4 & Murine Prnp-deficient Hippocampal neuronal cells \\
\hline HRP & Horseradish peroxidase \\
\hline IAA & lodoacetamide \\
\hline IEF & Isoelectric focusing \\
\hline
\end{tabular}




\begin{tabular}{|c|c|}
\hline $\lg G$ & Immunoglobulin G \\
\hline IPG & Immobilized pH gradient \\
\hline $\mathrm{kDa}$ & Kilodalton \\
\hline LB & Luria-Bertani broth \\
\hline LC/MS-MS & Liquid chromatography and tandem mass spectrometry \\
\hline LSM & Laser-scanning microscope \\
\hline $\min$. & Minute \\
\hline $\mathrm{ml}$ & Milliliter \\
\hline MTS & $\begin{array}{l}\text { (3-(4,5-dimethylthiazol-2-yl)-5-(3-carboxymethoxyphenyl)-2-(4- } \\
\text { sulfophenyl)-2H-tetrazolium) }\end{array}$ \\
\hline MW & Molecular weight \\
\hline no. & Number \\
\hline ng & Nano gram \\
\hline OD & Optical density \\
\hline PBS & Phosphate buffered saline \\
\hline PCR & Polymerase chain reaction \\
\hline PDI & Protein disulphide isomerase \\
\hline PKC & Protein kinase $\mathrm{C}$ \\
\hline PLD & Phospholipase D \\
\hline PMS & Phenazine methosulfate \\
\hline PPlase & Peptidyl prolyl cis-trans isomerase \\
\hline ppm & Parts per million \\
\hline $\operatorname{PrP}^{\mathrm{C}}$ & Cellular prion protein \\
\hline $\mathrm{PrP}^{\mathrm{SC}}$ & Infectious isoform of prion protein \\
\hline PS & Penicillin Streptomycin \\
\hline rpm & Revolutions per minute \\
\hline Rab7a & Ras-related protein Rab-7a \\
\hline Rev & Reverse \\
\hline RT & Room temperature \\
\hline $\mathrm{s}$ & second \\
\hline SDS-PAGE & Sodium Dodecyl Sulphate Polyacrylamide Gel Electrophoresis \\
\hline siRNA & Small interfering RNA \\
\hline TBS & Tris buffered saline \\
\hline TBST & TBS with $0.1 \%$ Tween \\
\hline
\end{tabular}


TE

TEMED

Tris

TSES

WB

\section{Tris EDTA}

$\mathrm{N}, \mathrm{N}, \mathrm{N}^{\prime}, \mathrm{N}^{\prime}$-tetramethylethylenediamine Tris-(hydroxymethyl)-aminomethane Transmissible spongiform encephalopathies Western blot 


\section{Summary}

The cellular prion protein $\left(\mathrm{PrP}^{\mathrm{C}}\right)$ was highly conserved during the evolution of mammals [Pantera et al. 2009; Jiayu et al. 2009]. The gene tree deduced from the PrP sequences largely agrees with the species tree, indicating that no major deviations occurred in the evolution of the prion gene in different placental lineages [Teun van Rheede et al. 2003]. However, the cellular function of this ubiquitous protein is still not clear. The accumulation of misfolded and aggregated forms of $\operatorname{PrP}^{\mathrm{C}}$ (known as $\mathrm{PrP}^{\mathrm{Sc}}$ ) causes transmissible neurodegenerative diseases. Despite increasing knowledge concerning $\mathrm{PrP}^{\mathrm{Sc}}$, very little is known about the physiological characteristics of $\operatorname{PrP}^{\mathrm{C}}$ and its interaction with other cellular proteins.

The present study was undertaken to identify proteins interacting with $\mathrm{PrP}^{\mathrm{C}}$ that could provide new insights into its physiological functions and pathological role. Human $\mathrm{PrP}^{\mathrm{C}}$ was expressed in prion protein-deficient murine hippocampus (HpL3-4) neuronal cells. The $\mathrm{PrP}^{\mathrm{C}}$ along with its interacting proteins were affinity purified using STrEPTactin chromatography, in-gel digested, and then identified by Q-TOF MS/MS analysis. Forty three proteins appeared to interact with $\operatorname{PrP}^{\mathrm{C}}$ in this neuronal cell line. Of these, fifteen were already known for their interaction with $\operatorname{PrP}^{\mathrm{C}}$ or $\operatorname{PrP}^{\mathrm{Sc}}$, while twenty eight new proteins were identified. All 43 (known and new) proteins which were identified as interacting partners were structural constituents of the cytoskeleton. Some are involved in cell growth, some in metabolism, and some in energy pathways. In addition, proteins that are important for cell homeostasis, cell communication, signal transduction, stress response and protein folding were also among the newly identified interacting partners of $\operatorname{PrP}^{\mathrm{C}}$.

Interactions of two novel (newly discovered) interacting partners of the GTPase family (Rab7a and Arf1) which have a suggested role in vesicle trafficking as well as the cytoskeleton associated protein alpha-tubulin 1 were further investigated using confocal laser scanning microscopy and reverse co-immunoprecipitation. Both reverse coimmunoprecipitation and immunofluorescence results confirmed potential interactions of Rab7a, Arf1 and alpha-tubulin 1 with the $\operatorname{PrP}^{\mathrm{C}}$. SiRNA against the Rab7a gene was used to decrease the expression of Rab7a protein ("knockdown"), in $\operatorname{PrP}^{\mathrm{C}}$ expressing HpL3-4 and SH-SHY5Y cells. This depleted Rab7a expression led to the enhanced accumulation of $\operatorname{PrP}^{\mathrm{C}}$ in Rab9 positive endosomal compartments. The $\operatorname{PrP}^{\mathrm{C}}$ which 
accumulated within these Rab9 positive late endosomes remained sensitive to proteinase $\mathrm{K}$ digestion. Furthermore, Arf1 deactivation by brefeldin $\mathrm{A}$ treatment down regulated $\operatorname{PrP}^{\mathrm{C}}$ expression and redistributed $\mathrm{PrP}^{\mathrm{C}}$ into the cytosol, whereas nocodazole treatment increased $\mathrm{PrP}^{\mathrm{C}}$ expression and redistributed $\operatorname{PrP}^{\mathrm{C}}$ into the cytosol.

The work described demonstrated for the first time that Rab7a and Arf1 interact with $\operatorname{PrP}^{\mathrm{C}}$ and may possibly be involved in the cellular trafficking and distribution of $\operatorname{PrP}^{\mathrm{C}}$ into microtubules. These results highlight the pivotal involvement of endosomal compartments in the trafficking and regulation of $\mathrm{PrP}^{\mathrm{C}}$. 


\section{Introduction}

\subsection{Prions and prion biology}

The term prion (proteinaceous infectious particle) was coined by Stanley Prusiner in 1982. Prions are unique infectious agents devoid of nucleic acid which cause a group of fatal neurodegenerative diseases associated with the misfolding of the cellular prion protein $\left(\mathrm{PrP}^{\mathrm{C}}\right)$. Bovine spongiform encephalopathy (BSE), Scrapie in sheep, and Creutzfeldt-Jakob disease (CJD) in humans are among the most notable prion diseases.

\subsubsection{Prion diseases and infectivity}

In the past decade, prion diseases or transmissible spongiform encephalopathies (TSE) have received enhanced attention largely because of the potential risk for human infection with BSE or "mad cow disease." These diseases can affect subjects in many age groups causing a variety of motor or cognitive symptoms. The pathogenesis of prion diseases is attributed to the major conformational changes in the cellular form of prion protein $\left(\mathrm{PrP}^{\mathrm{C}}\right)$ which result in the diseased form of these proteins $\left(\mathrm{PrP}^{\mathrm{Sc}}\right)$ [Prusiner 1998a]. The BSE are uncommon but invariably fatal [Aguzzi 2000; Knight and Will 2004; Aguzzi and O'Connor 2010].

The first documented prion disease was CJD, characterized by Creutzfeldt in 1920 and Jakob in 1921. Later, studies of kuru among the Fore (http://www.everyculture.com/Oceania/Fore-i-Orientation-i.html) people of Papua-New Guinea indicated that disease transmission relies on a single protease-resistant protein component of the prion [Prusiner 1998a; Prusiner 1998b]. According to the "proteinonly" hypothesis, $\mathrm{PrP}^{\mathrm{Sc}}$ is a potentially infectious agent that uses a self-propagating reaction to convert $\mathrm{PrP}^{\mathrm{C}}$ into the disease form. Additionally, transmission of the disease requires the presence of $\operatorname{PrP}^{\mathrm{C}}$ [Bueler et al. 1993; Brandner et al. 1996; Legname et al. 2004; Sakudo and Ikuta 2009; Lee et al. 2010; Mallik et al. 2010].

The clinical symptoms of prion diseases vary in humans. The neuropathology of prion diseases is characterized by extensive neuronal death, accompanied by spongiform vacuolation as well as astro- and microgliosis to extracellular amyloid aggregates. The deposited extracellular amyloid contains the causative agent $\mathrm{PrP}^{\mathrm{Sc}}$. 
This amyloid accumulation occurs in the majority of prion diseases, but not in all cases. These accumulations lead to progressively severe motor disturbance and dementia resulting in death within a few months to several years after diagnosis. Whereas, in transmissible cases, death can occur years to decades after the initial infection.

\subsubsection{The Structure of prion protein}

The human form of $\mathrm{PrP}^{\mathrm{C}}$ consists of 253 highly conserved amino acids [Goldmann 1993]. The majority of the mature form is attached to the plasma membrane, anchored through the C-terminus glycosyl-phosphatidylinositol (GPI) (Figure 1A). The $\mathrm{N}$-terminal half of the $\operatorname{PrP}^{\mathrm{C}}$ polypeptide chain is essential for efficient clathrin-mediated endocytosis. Deletions within this region diminish internalisation of $\operatorname{PrP}^{C}$ and direct translocation of the $\mathrm{N}$-terminus of the polypeptide chain across the membrane and produce ${ }^{\text {Sec }}$ PrP or ${ }^{\mathrm{Ntm}} \mathrm{PrP}$ ) [Stahl et al. 1987]. In the C-terminus of the PrP, there are two conserved N-linked glycosylation sites for complex oligosaccharide attachment at residues 181 (Asn-Ile-Thr) and 197 (Asn-Phe-Thr) [Caughey et al. 1989; Lawson et al. 2005]. The molecular weight of $\operatorname{PrP}^{\mathrm{C}}$ is about 25-35 kDa, indicating the presence of post translational modification including variable glycosylation (non-, mono- and diglycosylated forms). The types of glycans attached to both full-length and truncated PrP appear to be extremely diverse. More than 50 sugar chains have been observed, using both biochemical and mass spectrometry methods [Rudd et al. 1999; Pan et al. 2002], to be differentially distributed in various areas of the central nervous system (CNS) [DeArmond et al. 1999; Beringue et al. 2003]. The C-terminus of PrP contains two cysteine residues (Cys 179 and Cys 214) where post translationally a disulphide bridge is formed [Caughey et al. 1989; Rudd et al. 2002]. The relevance of these modifications is still under investigation.

The $\mathrm{N}$-terminus of $\mathrm{PrP}^{\mathrm{C}}$ contains an octapeptide repeat $(\mathrm{OR})$ domain [Roucou and LeBlanc 2005]. This domain is made up of a PQGGGGWGQ peptide sequence followed by four identical repeats of PHGGGWGQ. These last four ORs show similarity to the $\mathrm{BH} 2$ domain found in the $\mathrm{Bcl}-2$ family of proteins, suggesting that the protein may play a role in cell survival. In addition, the repeating motif provides a region rich in histidine, which is known to bind copper ions. A domain comprised of highly hydrophobic residues is found between amino acids 110 and 135 of PrP and plays an important role in generating transmembrane proteins [Lopez et al. 1990]. The NMR 
spectroscopy deduced tertiary structure of the cellular prion protein (Figure 1B) shows predominantly an $\alpha$-helical (42\%) folded $\mathrm{C}$-terminal domain and a tangled $\mathrm{N}$-terminal flexible domain [Riek et al. 1997]. In contrast to the pathological form ( $\mathrm{PrP}^{\mathrm{Sc}}$ ), the $\operatorname{PrP}^{\mathrm{C}}$ is sensitive to proteinase $\mathrm{K}(\mathrm{PK})$ digestion.

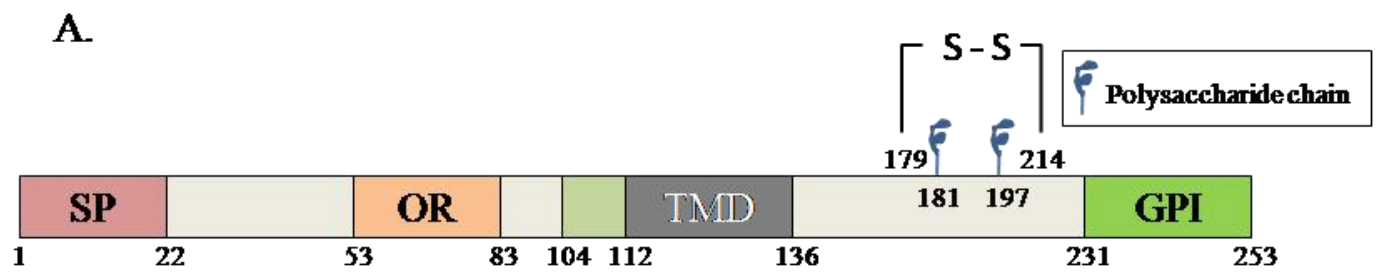

B.
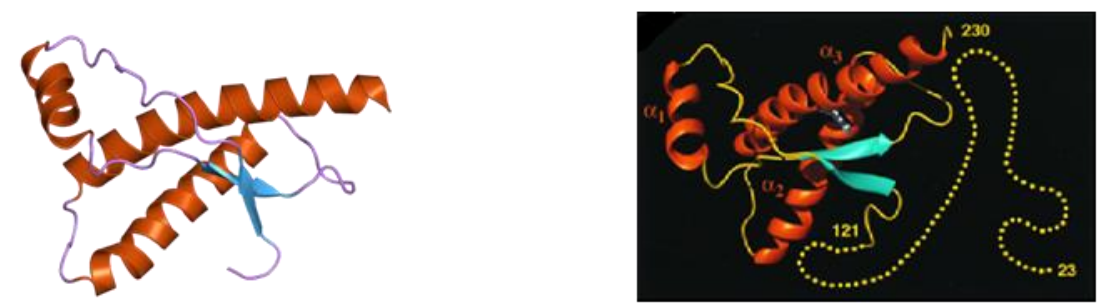

Figure 1 The structural features of the cellular prion protein: $(A)$ The schematic representation of $\mathrm{PrP}^{\mathrm{C}}$ structure contains an $\mathrm{N}$-terminal signal peptide (SP) and a glycosylphosphatidylinositol (GPI) anchor signal at the C-terminus. In addition, $\operatorname{PrP}^{\mathrm{C}}$ has an octapeptide repeat (OR) region, a hydrophobic transmembrane domain (TMD), one disulphide bridge and two $\mathrm{N}$-linked glycosylation sites $\left({ }^{\zeta}\right.$ ) (B) Cartoon of the three-dimensional structure of the human $\operatorname{PrP}^{\mathrm{C}}$ [Riek et al. 1997].

\subsubsection{Biosynthesis and internalization of $\operatorname{PrP}^{\mathrm{C}}$}

The biosynthesis of $\operatorname{PrP}^{\mathrm{C}}$ is similar to that of other membrane and secreted proteins. $\mathrm{PrP}^{\mathrm{C}}$ contains a specific N-terminal signal peptide (SP) which translocates it into the endoplasmic reticulum (ER) from where it transits the Golgi on its way to the cell surface [Harris 2003a]. Targeting of the $\mathrm{PrP}^{\mathrm{C}}$ to the $\mathrm{ER}$ is subject to several posttranslational modifications including cleavage of the $\mathrm{N}$-terminal signal peptide, addition of $\mathrm{N}$-linked oligosaccharide chains, formation of a single disulphide bond, and the attachment of GPI anchor at C-teminus [Haraguchi et al. 1989; Stahl et al. 1987; Turk et al. 1988]. 
Following, glycosylation and the addition of the GPI anchor, $\operatorname{PrP}^{\mathrm{C}}$ is transported to the cell surface where it is attached via the GPI anchor [Borchelt et al. 1990a] (Figure 2). The majority of $\operatorname{PrP}^{\mathrm{C}}$ is found in detergent-resistant raft domains on the cell surface [Gorodinsky and Harris 1995; Naslavsky et al. 1997] and constitutively cycles between the plasma membrane and the endocytic compartment [Shyng et al. 1993]. Kinetic analysis demonstrates that $\mathrm{PrP}^{\mathrm{C}}$ molecules cycle through the cell with a transit time of approximately 60 min [Magalhaes et al. 2002]. Shyng et al. in 1993 reported that most of the protein is recycled without degradation. Internalization of $\operatorname{PrP}^{\mathrm{C}}$ occurs possibly via i) clathrin coated pits [Shyng et al. 1995a] and/or ii), caveolae-like membranous domains [Vey et al. 1996], or sphingolipid/cholesterol rafts [Shyng et al. 1995b].

i) Clathrin-mediated endocytosis is a process by which cells internalize molecules by the inward budding of plasma membrane. It involves the recruitment of clathrin and adaptor proteins, such as AP-2 at phosphoinositides in the membrane [Gaidarov and Keen 1999]. Shyng et al in 1994 used hypertonic media to disrupt clathrin lattices and thereby impair endocytosis via clathrin and reported impaired $\operatorname{PrP}^{\mathrm{C}}$ internalization, suggesting that $\mathrm{PrP}^{\mathrm{C}}$ may not behave like other GPI anchored proteins.

ii) Caveolae is a special type of $50-100 \mathrm{~nm}$ in diameter lipid raft which invaginates the plasma membrane. Internalization of proteins through caveolae has been suggested to divert proteins from the endosomal/ lysosomal pathway [Pelkmans et al. 2001]. Vey et al. in 1996 showed that both $\operatorname{PrP}^{C}$ and $\operatorname{PrP}^{\mathrm{Sc}}$ proteins localized in these caveolae and may use these caveolae for their internalization.

The prion protein is highly expressed within the nervous system, although its expression changes among differing cell types and among neurons with distinct neurochemical phenotypes. Various cellular components of the immune system, in the bone marrow, blood, and peripheral tissues, also express substantial amounts of $\operatorname{PrP}^{\mathrm{C}}$. $\operatorname{PrP}^{\mathrm{C}}$ has also been reported in endosomes containing transferrin receptors in adult mouse sensory neurons and N2a neuroblastoma cells [Sunyach et al. 2003]. Also in neurons, $\operatorname{PrP}^{\mathrm{C}}$ has been demonstrated both in the Golgi and within cytoplasmic organelles resembling endosomes [Laine et al. 2001]. Although the majority of $\operatorname{PrP}^{\mathrm{C}}$ is expressed on the cell surface [Borchelt et al. 1990b; Mironov et al. 2003], significant amounts are present within the cytoplasm of a subpopulation of neurons in the cortex, hippocampus and thalamus [Mironov et al. 2003]. Some of these cytoplasmic PrP may arise from the 
endocytosed cell surface PrP. A few cytosolic PrP are derived from the endoplasmic reticulum associated degradative (ERAD) pathway. Accumulation of PrP in the cytosol of cells treated with proteasomal inhibitors has been reported [Ma and Lindquist 1999], indicating that excess $\mathrm{PrP}^{\mathrm{C}}$ is degraded by the proteasome system [Yedidia et al. 2001]. According to another hypothesis, PrP can also be translated, after losing its signal peptide [Rane et al. 2004], as a cytosolic protein which retains both the $\mathrm{N}$-terminal and C-terminal signal peptides [Drisaldi et al. 2003].

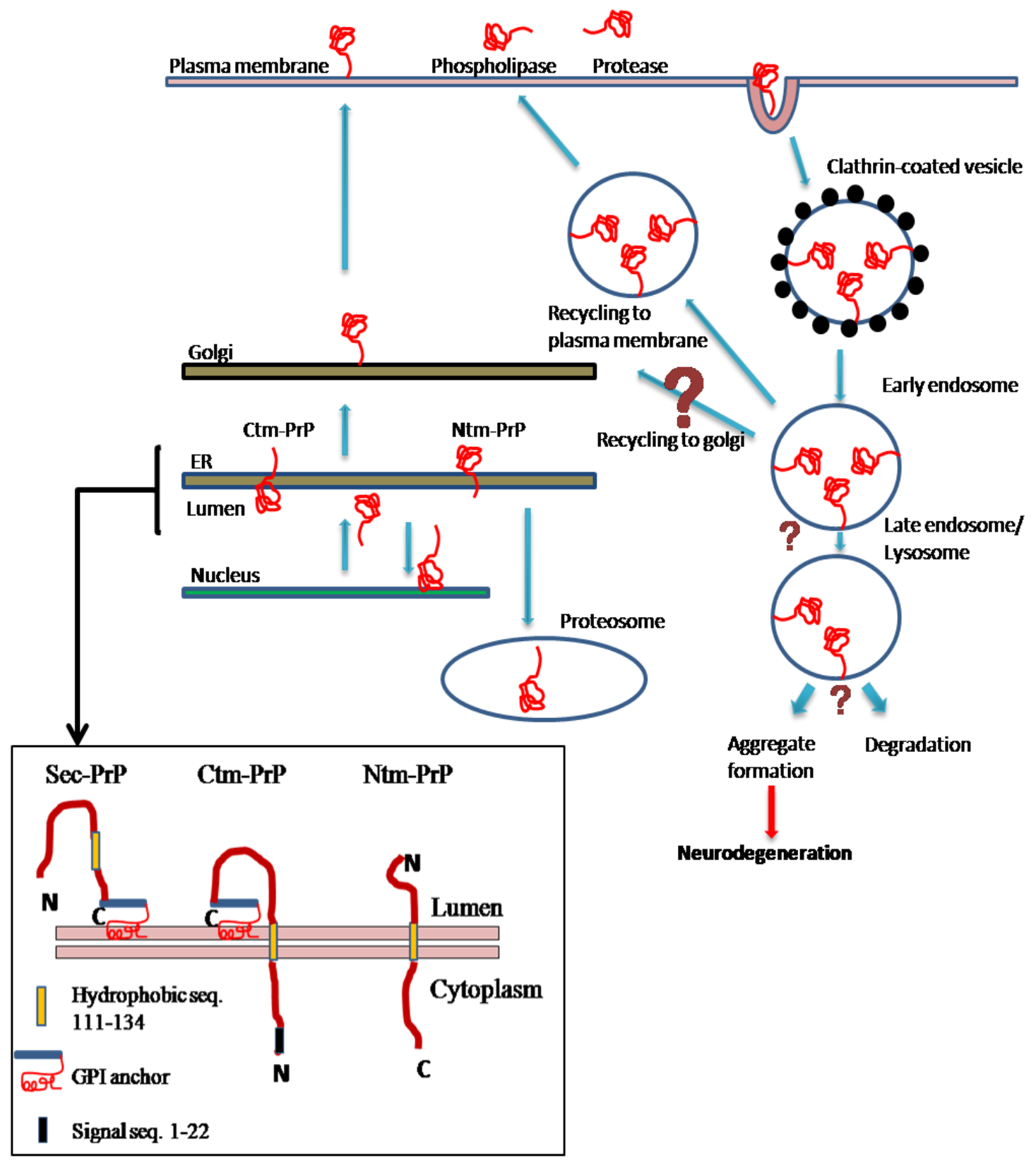

Figure 2 Biosynthesis and cellular trafficking of $\operatorname{PrP}^{C}$ : The $\operatorname{PrP}^{C}$ synthesis, folding, glycosylation and GPI anchor addition all take place in the endoplasmic reticulum (ER). Three different 
topological forms of PrP are synthesized in the ER (Ctm-PrP: with the C-terminus in the lumen and the Nterminus in the cytosol, Ntm-PrP: with the N-terminus in the lumen and the C-terminus in the cytosol and Sec-PrP: secretary PrP). Modified $\operatorname{PrP}^{\mathrm{C}}$ then translocate to the outer leaflet of the plasma membrane and cycle between the plasma membrane and the endocytic compartments (Zafar et al. submitted).

\subsubsection{Physiological functions of $\operatorname{PrP}^{\mathrm{C}}$}

The exact function of $\mathrm{PrP}^{\mathrm{C}}$ is still not clear; however, several putative functions have been reported including e.g. regulatory activity of copper metabolism [Brown et al. 1997a; Korte et al. 2003; Toni et al. 2005; Varela-Nallar et al. 2006; Turu et al. 2008], antioxidant effects [Brown et al. 1997b; Brown et al. 2001; Sakudo et al. 2005; Anantharam et al. 2008], neuronal differentiation [Mouillet-Richard et al. 1999; MouilletRichard et al. 2000; Steele et al. 2006; Lima et al. 2007; Barenco et al. 2009], neuroprotective signaling, and synaptic function [Collinge et al. 1994; Re et al. 2006].

$\mathrm{PrP}^{\mathrm{C}}$ is also found in pre-synaptic nerve terminals, synapses in the brain and neuromuscular junctions [Brown, Clive, and Haswell 2001]. Furthermore, $\operatorname{PrP}^{\mathrm{C}}$ may be a part of synaptic vesicle membranes, since the $\operatorname{PrP}^{C}$ interacting protein synapsin $I$ is associated with small synaptic vesicles [Spielhaupter and Schatzl 2001] and $\mathrm{PrP}^{\mathrm{C}}$ colocalizes with the pre-synaptic vesicle protein synapthophysin [Fournier et al. 1995; Fournier 2008].

$\mathrm{PrP}^{\mathrm{C}}$ affects neurotransmitter release via synaptic vesicles as shown for acetylcholine in the neuromuscular junction [Re et al. 2006]. This would suggest a role in the recycling of vesicles or a more direct role in synaptic activity. The latter has been suggested by some electrophysiological studies conducted in mice devoid of $\mathrm{PrP}^{\mathrm{C}}$, which demonstrate weakened $\mathrm{GABA}_{A}$-mediated fast inhibition [Collinge et al. 1994]. Recombinant PrP induces rapid polarization and development of synapses in embryonic rat hippocampal neurons [Kanaani et al. 2005]. In vivo accumulation of PrP deposits correlate with abnormal synaptic protein expression in the cerebellum of CJD brains [Ferrer 2002], and Scrapie-infected mice showed a loss of synapses [Jeffrey et al. 2000], intrinsic dysfunction of cortical and hippocampal neurons [Jeffrey et al. 1996], and altered properties of the membrane and synapses [Johnston et al. 1997]. Beyond synaptic function, $\operatorname{PrP}^{\mathrm{C}}$ binds copper via histidines in the octarepeat region and could regulate copper concentration in the synaptic region of neurons and decrease oxidative stress in synapses [Herms et al. 1999; Kretzschmar et al. 2000; Morot-Gaudry- 
Talarmain et al. 2003]. This anti-oxidative activity of $\operatorname{PrP}^{C}$ has been shown to be the result of copper/zinc-dependent superoxidedismutase activity [Brown et al. 1997b; Brown et al. 1999; Rachidi et al. 2003; Sakudo et al. 2005]. The signaling function of $\operatorname{PrP}^{\mathrm{C}}$ has been demonstrated by the activation of the non-receptor tyrosine kinase fyn [Kanaani et al. 2005; Mouillet-Richard et al. 2000; Santuccione et al. 2005], which is enriched in brain synaptosomes.

\subsection{Cellular trafficking}

\subsubsection{Vesicular trafficking}

Small membrane-bounded vesicles transport proteins from one organelle to another in the secretory and endocytic pathways. These vesicles bud from the membrane of a particular "parent" organelle and fuse with the membrane of a particular "target" (destination) organelle. They are critical for the sorting of proteins newly made in the rough endoplasmic reticulum and of proteins internalized from the cell surface (Figure 2). There are three well characterized transport vesicles - COPI (which transport proteins from the rough ER to the Golgi), COPII (which transport proteins in the retrograde direction between Golgi cisternae and from the cis-Golgi back to the rough ER), and clathrin vesicles (which transport proteins from the plasma membrane and the trans-Golgi network to the late endosomes). All types of coated vesicles are formed by the polymerization of cytosolic coat proteins, initiated by the recruitment of a small GTP-binding protein, onto a donor (parent) membrane. Then the complexes of coat and adapter proteins in the cytosol bind to the cytosolic domains of membrane cargo and receptor proteins; the latter bring soluble luminal cargo proteins into the budding vesicle. Shortly after vesicle release, the coat protein is shed exposing proteins (SNARE proteins) required for fusion with the target membrane [Kaiser and FerroNovick 1998].

\subsubsection{RAS superfamily of monomeric GTP-binding proteins}

In eukaryotes, a family of GTP-binding proteins (Arf, Rab, Rho and dynamin families) regulates vesicle trafficking from the formation of vesicles on donor membranes to facilitating vesicle docking on target membranes [Bucci et al. 2000; Nielsen et al. 2008]. The budding of coated vesicles is initiated when molecules of Arf 
protein exchange their bound GDP for GTP, a reaction catalyzed by an enzyme in the Golgi membrane. After Arf-GTP binds to Arf receptors on Golgi cisternae, coatomers bind to the cytosolic face of the Golgi cisterna and polymerize into a fibrous coat that induces vesicle budding. Because they can bind to coatomer, certain integral membrane proteins are incorporated into the vesicles. These include a V-SNARE, which functions in targeting vesicles to appropriate acceptor membranes [Weis and Scheller 1998]. Soluble proteins in the lumen are selected for entry into these vesicles by binding to specific membrane receptor proteins. Fatty acyl CoA is essential for the final separation of the transport vesicle from the donor membrane, but how this happens is not known. Finally, hydrolysis of GTP bound to the Arf proteins causes depolymerization of the coat and release of coatomers and ARF-GDP [Rothman 1996].

In the case of Rab-proteins, a cytosolic protein called GDI catalyzes the exchange of GDP which binds to cytosolic Rab, inducing a conformational change in Rab. This enables Rab to bind to a surface protein on a particular transport vesicle. After vesicle fusion, the GTP bound to the Rab protein is hydrolyzed to GDP triggering the release of the Rab protein which can then undergo another cycle of GDP-GTP exchange, binding, and hydrolysis. The rate of vesicle fusion is controlled by the absolute amount of Rab-GTP, which is modulated by unidentified protein regulators [Schimmoller et al. 1998; Zerial and McBride 2001]. Several lines of evidence support the involvement of specific Rab proteins as timers of vesicle fusion events. For instance, Rab3 is found predominantly in the donor compartment [Tuvim et al. 2001] and Rab5 is localized to early endosomes, organelles that form from clathrin-coated vesicles, just after they bud from the plasma membrane during receptor-mediated endocytosis [Morrison et al. 2008]. Rab7 is known to be associated with late endosomes and regulates membrane transport leading the transition from early to late endosomes [Feng et al. 1995]. Thus, some individual Rab proteins are clearly essential for specific vesicle fusion reactions to occur [Markgraf et al. 2007]. However, it is not known whether Rab proteins interact with V-SNARE proteins to determine the specificity of vesicle fusion with target membranes [Lodish 2004]. 


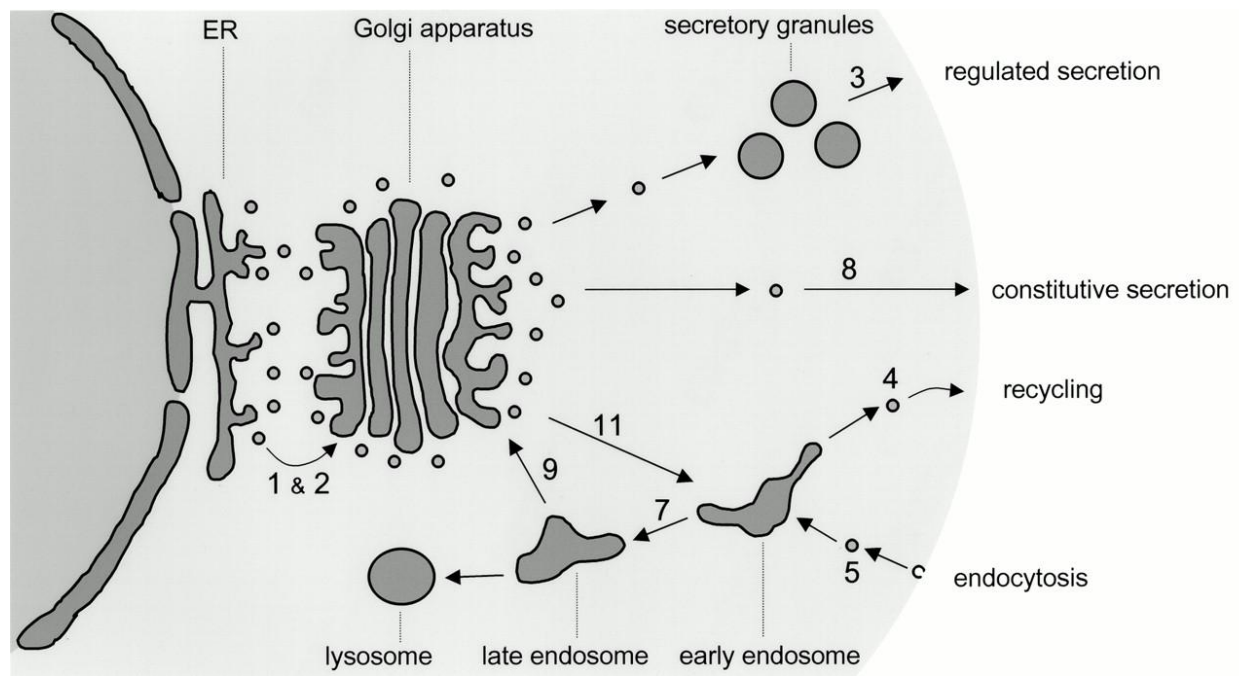

Figure 3 Rab proteins and vesicular trafficking: Individual Rab proteins are associated with distinct intracellular compartments. In some cases, the Rab protein is found predominantly localized on the target compartment (e.g., Rab 5 trafficking from plasma membrane to early endosomes), whereas in other cases it is found predominantly on the donor compartment (e.g., Rab3 in the regulation of exocytosis in secretory granules) [Tuvim et al. 2001].

\subsubsection{Microtubules}

The cytoskeleton is a network of fibrous elements, consisting primarily of microtubules, actin microfilaments, and intermediate filaments which are found in the cytoplasm of eukaryotic cells. Microtubules are $25 \mathrm{~nm}$ in diameter cytoskeletal fibers which are formed by polymerization of $\alpha, \beta$-tubulin monomers (which belong to an ancient family of GTPases) and exhibit structural and functional polarity. They are important components of cilia, flagella, the mitotic spindle, and other cellular structures [Lodish 2004].

Membrane vesicles are transported along microtubules in every eukaryotic cell, the best-studied system is the intracellular movement of Golgi vesicles. In cultured fibroblasts, the Golgi complex is concentrated near the microtubule-organizing centre (MTOC). During mitosis or after drug (colcemid) induced depolymerization of microtubules, the Golgi complex breaks into small vesicles that are dispersed throughout the cytosol. When the cytosolic microtubules re-form during interphase or after removal of the colcemid, the Golgi vesicles move along these microtubule tracks towards the MTOC. There these Golgi vesicles re-aggregate to form large membrane complexes [Schmoranzer and Simon 2003]. In addition to the Golgi complex, 
microtubules are also associated with the endoplasmic reticulum (ER). Fluorescence microscopy, using anti-tubulin antibodies and $\mathrm{DiOC}_{6}$, a fluorescent dye specific for the $E R$, reveals an anastomosing network of tubular membranes in the cytosol that colocalizes with microtubules. If microtubules are destroyed by drugs such as nocodazole or colcemid, then the ER loses its network-like organization. After the drug is washed from the cell, tubular fingers of ER grow as new microtubules. This close association between ER and intact microtubules suggests that certain proteins act to bind ER membranes to microtubules [Lodish 2004].

In most familial cases of neurodegenerative disorders, dysfunction of the cytoskeleton changes vesicular biogenesis, vesicle/organelle trafficking, and synaptic signaling [Fletcher and Mullins 2010]. Cytoskeleton disruption is caused by activation of DNA damage followed by a cascade of events including mitochondrial dysfunction and oxidative stress [McMurray 2000]. The endosomes move along with microtubules, and microtubule disruption may produce enormous Rab5 and Rab7 positive endosomes. During clathrin-coated endocytosis the primary endocytic vesicles contain Rab5 and Arf1 domains but they do not contain Rab7. Later Rab7 is recruited to these endosomes and the other early endosome-associated small GTPases are eliminated The Rab7containing endosomes move along microtubules and fuse with other late endosomes.

\subsection{Interactomics}

Proteins rarely act alone; rather they interact with other molecules to perform their functions. In most biological systems protein-protein interactions are of critical importance. There are various approaches used to identify these interactions, such as the yeast two-hybrid system, immunoprecipitation, tagged purifications, or affinity purification-mass spectrometry.

\subsection{1 $\mathrm{PrP}^{\mathrm{C}}$ - putative interacting partners}

The molecules interacting with $\operatorname{PrP}^{\mathrm{C}}$, because of their intrinsic activity, localization in the same cell compartment and within a specific signaling pathway, are a major focus of studies investigating the possible functions of $\mathrm{PrP}^{\mathrm{C}}$. The first known interacting partners of $\mathrm{PrP}^{\mathrm{C}}$ were Pli45 and Pli110 [Oesch et al. 1990]. Pli 45 was identified as glial fibrillary acidic protein (GFAP), an astrocytic marker that accumulates concomitantly with disease-associated $\mathrm{PrP}^{\mathrm{C}}$ during TSEs [DeArmond et al. 1992]. The 
two-hybrid system of yeast was used to identify anti-apoptotic protein Bcl-2 [Kurschner and Morgan 1995; Kurschner and Morgan 1996]; Heat shock protein 60 [Edenhofer et al. 1996]; the 37kDa laminin receptor precursor [Rieger et al. 1997]; synapsin lb; adaptor protein Grb2, and prion interaction protein Pint 1 [Spielhaupter and Schatzl 2001].

$\operatorname{PrP}^{\mathrm{C}}$ was also immunoprecipitated with antibodies to the binding proteins calnexin, protein disulphide isomerase, and calreticulin [Capellari et al. 1999]. It has also been shown that $\mathrm{PrP}^{\mathrm{C}}$ binds with many proteins including laminin [Graner et al. 2000]; neural cell adhesion molecules ( $\mathrm{N}$-CAMs) [Schmitt-Ulms et al. 2001]; $67 \mathrm{kDa}$ laminin receptor [Gauczynski et al. 2001]; glycosaminoglycans (GAGS) [Priola and Caughey 1994; Pan et al. 2002]; stress inducible protein STI-1 [Zanata et al. 2002]; casein kinase 2, dystroglycan, aldolase $\mathrm{C}$, heterogeneous nuclear ribonucleoprotein A2/B1 [Lasmezas 2003]; tubulin [Nieznanski et al. 2005]; vitronectin [Hajj et al. 2007] and signal protein 14-3-3 beta [Mei et al. 2009]. The functional influences of these interacting partners are still largely unknown, but both the biochemical features and the biological functions of $\mathrm{PrP}^{\mathrm{C}}$ may change through these interactions. 


\subsection{Aims of the Study}

In the present study experiments were designed to identify interacting partners of $\operatorname{PrP}^{\mathrm{C}}$ using an affinity purification strategy. In recent years many groups have tried to identify these interacting proteins; however, the hydrophobic nature and intracellular trafficking of $\operatorname{PrP}^{\mathrm{C}}$ pose a challenge. The use of One-STrEP-tag affinity purification was hypothesized to yield better results with less background contaminants due to the high specificity and binding affinity of STrEP-tactin. These studies were designed to provide a more comprehensive set of potential interacting proteins and lead to greater insight into the various cellular events mediated through $\operatorname{PrP}{ }^{C}$.

The following strategy was adopted to identify and characterize $\operatorname{PrP}^{\mathrm{C}}$ interacting proteins:

1. Transient $\operatorname{PrP}^{\mathrm{C}}$ expression in neuronal cell models.

2. Purification and identification of interacting partners of $\operatorname{PrP}^{\mathrm{C}}$.

3. Characterization of GTPase related (Rab7a and Arf1) and alpha-tubulin 1 interacting proteins involved in $\mathrm{PrP}^{\mathrm{C}}$ trafficking and internalization. 


\section{Materials}

\subsection{Antibodies}

Antibodies used for immunoblotting (IB), immunoprecipitation (IP) and immunofluorescence (IF) are listed in Table 1

Table 1 List of antibodies and their application in present study

\begin{tabular}{|c|c|c|c|c|}
\hline Primary Antibody & Origin & $\begin{array}{c}\text { Dilution } \\
\text { IB/IP }\end{array}$ & $\begin{array}{c}\text { Dilution } \\
\text { IF }\end{array}$ & Company/ Cat. No. \\
\hline 3F4 PrP & $\begin{array}{l}\text { mouse } \\
\text { IgG2a }\end{array}$ & $1: 1000$ & $1: 200$ & Chemicon/MAB1562 \\
\hline $6 \mathrm{H} 4 \mathrm{PrP}$ & mouse lgG1 & $1: 500$ & - & Prionics/01-010 \\
\hline a-Tubulin & rabbit IgG & $1: 1000 / 1: 100$ & $1: 50$ & Cell Signaling/2125 \\
\hline $\begin{array}{l}\text { Actin } \\
\text { (cytoplasmic 1) }\end{array}$ & mouse lgG1 & $1: 1000$ & $1: 200$ & Sigma/A5441 \\
\hline Annexin A2 & mouse IgG & $1: 5000$ & - & $\begin{array}{l}\text { BD } \\
\text { Transduction/610069 }\end{array}$ \\
\hline Annexin A5 & mouse IgG & $1: 5000$ & - & abcam/ab14196 \\
\hline Arf1 & mouse lgG1 & $1: 500 / 1: 500$ & $1: 500$ & $\begin{array}{l}\text { Affinity BioReagents/ } \\
\text { MA3-060 }\end{array}$ \\
\hline Cofilin-1 & rabbit lgG & $1: 1500$ & $1: 200$ & Sigma/C8736 \\
\hline Peroxiredoxin-1 & rabbit lgG & $1: 1000$ & - & abcam/ab15571 \\
\hline Rab7(D95F2) & rabbit lgG & 1:1000/1:100 & $1: 50$ & Cell Signaling/9367 \\
\hline Rab9(D52G8) & rabbit IgG & - & $1: 50$ & Cell Signaling/5118 \\
\hline SAF 70 PrP & $\begin{array}{l}\text { mouse } \\
\operatorname{lgG} 2 b\end{array}$ & $1: 1500$ & - & SPIbio/A03206 \\
\hline STrEP MAB-Classic & mouse lgG1 & $1: 1000$ & $1: 100$ & IBA/ 2-1507-001 \\
\hline $\begin{array}{l}\text { Tropomyosin (alpha- } \\
4 \text { chain) }\end{array}$ & rabbit & $1: 1500$ & - & Chemicon/Ab5449 \\
\hline Vimentin & $\begin{array}{l}\text { mouse } \\
\text { lgG2a }\end{array}$ & $1: 5000$ & - & Dako/M7020 \\
\hline
\end{tabular}




\begin{tabular}{lcccl}
\hline \multicolumn{1}{c}{$\begin{array}{c}\text { Secondary } \\
\text { antibody }\end{array}$} & Origin & $\begin{array}{c}\text { Dilution } \\
\text { IB }\end{array}$ & $\begin{array}{c}\text { Dilution } \\
\text { IF }\end{array}$ & Company/ Cat. No. \\
\hline a-mouse-HRP & rabbit & $1: 5000$ & - & IBA/2-1591-001 \\
a-mouse-HRP & goat & $1: 15000$ & - & Bio-Rad/170-6516 \\
a-rabbit-HRP & goat & $1: 5000$ & - & Bio-Rad/170-6515 \\
a-mouse-Cy3 & goat & - & $1: 200$ & $\begin{array}{l}\text { Dianova/115-165- } \\
146\end{array}$ \\
& goat & - & $1: 200$ & $\begin{array}{l}\text { Invitrogen/522263 } \\
\text { a-mouse-A488 }\end{array}$ \\
a-rabbit-A488 & goat & - & $1: 200$ & $\begin{array}{l}\text { Molecular } \\
\text { Probes/A11070 }\end{array}$ \\
\hline
\end{tabular}

\subsection{Antibiotics, enzymes and standards}

Table 2 List of antibiotics, enzymes and standards

\section{Antibiotics}

Company/ Cat. No.

Ampicillin

Calbiochem/171254

Geniticin

Invitrogen/10131019

Kanamycin

Invitrogen/11815-024

\section{Enzymes}

Rstriction Endonuclease Xba I

Boehringer / 674257

Restriction enzymes (Others)

New England Biolabs/ Germany

Standards (DNA \& protein)

Mass Ruler DNA ladder mix 10kDa

Fermentas/SM0403S

DNA ladder low range

Fermentas/SM0383S

$\lambda \mathrm{DNA} /$ HindlII fragments

GibcoBRL/10382-018

C-Terminus One-STrEP-tag Protein

IBA/ 2-1011-100

Ladder

Precision Plus Protein Standard

Bio-Rad/ 161-0374 


\subsection{Bacterial strain and culture media}

Table 3 List of bacterial strain and culture media

Company/ Cat. No.

Bacterial strains (E.coli) DH5a/Top10 Invitrogen-18258-012/C4040-10

LB-medium

Applichem/A0954,9010

LB-agar

Applichem/A0927,9010

Agarose

Biozym/840004

Low melting agarose

Biozym/840101

\subsection{Chemicals}

All chemicals used in this study were obtained from Amersham (Freiburg, Germany), Sigma and Fluka (Deisenhofen, Germany), Merck (Haar, Germany), Applichem (Darmstadt, Germany), Serva (Heidelberg, Germany), Roth (Karlsruhe, Germany) and BioRad (München, Germany), if not stated otherwise in the text.

\subsection{Eukaryotic cells and culture media}

Prnp-deficient (Prnp ${ }^{-/}$) Murine hippocampal neuronal cells (HpL3-4): HpL3-4 cells were kindly provided by Prof. Takashi Onodera, Department of Molecular Immunology, School of Agricultural and Life Sciences, University of Tokyo, Japan. The cells were cultured in Dulbecco's modified Eagle's medium (DMEM) (Sigma-Aldrich Chemie, Germany), supplemented with 10\% fetal bovine serum (FBS) (Biochrom AG, Germany), and 1\% penicillin/Streotomycin (PS) (Biochrom AG, Germany) at $37^{\circ} \mathrm{C}$, supplied with $5 \% \mathrm{CO}_{2}$ and $95 \%$ humidity.

SH-SY5Y (Stably expressing PrPC) cells: SH-SY5Y cells were obtained from Prof. Walter Schulz-Schaeffer, Department of Neuropathology, University medical center (UMG), Goettingen, Germany. The cells were cultured in DMEM, supplemented with $10 \%$ FBS, $1 \%$ PS, Geniticin $200 \mu \mathrm{g} / \mathrm{ml}$, at $37{ }^{\circ} \mathrm{C}$, supplied with $5 \% \mathrm{CO}_{2}$ and $95 \%$ humidity.

Human embryonic kidney (HEK) 293 cells: HEK-293 cells were purchased from the American Type Culture Collection (ATCC). The cells were cultured in DMEM, supplemented with $10 \%$ FBS, and $1 \% \mathrm{PS}$, at $37^{\circ} \mathrm{C}$, supplied with $5 \% \mathrm{CO}_{2}$ and 95\% humidity. 


\subsection{Instruments and other materials}

Table 4 List of the instruments used in this study

\begin{tabular}{|c|c|c|}
\hline Appliance & Model or Description & Manufacture \\
\hline Bio-safety Cabinet & Hera safe KS & Heraeus/ Osterode, Germany \\
\hline \multirow[t]{5}{*}{ Centrifuges } & $5415 \mathrm{C}$ & Eppendorf/Hamburg,Germany \\
\hline & Rotina 35R & Hettich/ Tuttlingen, Germany \\
\hline & Mikro 200 & Hettich/ Tuttlingen, Germany \\
\hline & Minifuge $T$ & Heraeus /Hanau, Germany \\
\hline & Optima TL 100 & Beckman/ Krefeld, Germany \\
\hline Chamber slide & $\begin{array}{l}\text { Lab-Tek }^{\text {TM }} \text { II } \quad \text { Chamber } \\
\text { Slide, } 154534\end{array}$ & nunc/ New York, USA \\
\hline Culture dishes & $60 \mathrm{~mm}, 351016$ & Becton Dickinson /NJ, USA \\
\hline Electro blotting apparatus, & Mini Trans-Blot®, & Bio-Rad /Munich, Germany \\
\hline Electrophoresis apparatus, & Mini-Protean® III, & Bio-Rad /Munich, Germany \\
\hline Electroporation cuvette & $1 \mathrm{~mm}, 748011$ & Biozym/ Oldendorf, Germany \\
\hline Freeze drier & Alpha 1-4 LD & SciQuip Ltd/ Shropshire, UK \\
\hline $\begin{array}{l}\text { Gene Pulser Xcell } \\
\text { Electroporation Systems }\end{array}$ & $165-2660$ & Bio-Rad/ California, USA \\
\hline Heated magnetic stirrer & iKAMAG RCT & $\begin{array}{l}\text { IKA-Labortechnik/ Staufen, } \\
\text { Germany }\end{array}$ \\
\hline Ice machine & - & Ziegra /Isernhagen, Germany \\
\hline Incubator & IFE 400 & $\begin{array}{l}\text { Memmert/ } \\
\text { Germany }\end{array}$ \\
\hline IPG strips & 163-2002, 7 cm, pH 3-10 & Bio-Rad/ Munchen, Germany \\
\hline Microscope & Zeiss LSM 510 Meta & $\begin{array}{l}\text { Carl Zeiss/ Goettingen, } \\
\text { Germany }\end{array}$ \\
\hline Microwave oven & ER-6320 PW & $\begin{array}{l}\text { Brother International/ Bad } \\
\text { Vilbel, Germany }\end{array}$ \\
\hline Power supply & Power Pac 300 & Bio-Rad /Munich, Germany \\
\hline PROTEAN IEF cell & $165-4001$ & Bio-Rad/ Munchen, Germany \\
\hline Safe-Lock tubes & $0.2,0.5,1.5$ and $2 \mathrm{ml}$ & $\begin{array}{l}\text { Eppendorf } \\
\text { Germany }\end{array}$ \\
\hline Semi-Dry transfer Cell & Transblot SD & Bio-Rad/Munchen, Germany \\
\hline
\end{tabular}




\begin{tabular}{|c|c|c|}
\hline Serological pipettes & $2,5,10,25 \mathrm{ml}$ & Sarstedt /Germany \\
\hline plastic tubes & 15 and $50 \mathrm{ml}$ & \\
\hline $\mathrm{pH}$ meter & pH 526 & WTW/ Weilheim, Germany \\
\hline Shakers & CERTOMAT R & $\begin{array}{l}\text { Sartorius/ Goettingen, } \\
\text { Germany }\end{array}$ \\
\hline \multirow[t]{2}{*}{ Spectrophotometers } & EL808 & $\begin{array}{l}\text { Bioteck instruments/Winooski- } \\
\text { vermont, USA }\end{array}$ \\
\hline & DU 7500 & Beckman/ Krefeld, Germany \\
\hline Sterile filter Nalgene & $0.2 \mu \mathrm{m}$ & $\begin{array}{l}\text { Sartorius/ Goettingen, } \\
\text { Germany }\end{array}$ \\
\hline Sterile filter pipette tips & - & Biozym /Oldendorf, Germany \\
\hline Syringes BD Discardit & $2,5,20 \mathrm{ml}$ & Becton Dickinson /NJ, USA \\
\hline Thermal Cycler & TGradient & $\begin{array}{l}\text { Biometra/ } \\
\text { Germany }\end{array}$ \\
\hline Thermomixer & 5436 & $\begin{array}{l}\text { Eppendorf/ Hamburg, } \\
\text { German }\end{array}$ \\
\hline UV-transilluminator & $200 \times 200 \mathrm{~mm}$ & $\begin{array}{l}\text { Bachofer/ } \\
\text { Germany }\end{array}$ \\
\hline Vacuum drier & UNIVAPO 150H & $\begin{array}{l}\text { UNIEQUIP/ } \\
\text { Germany }\end{array}$ \\
\hline Vortexer & Genie $2^{\mathrm{TM}}$ & $\begin{array}{l}\text { Bender and Hobein /Zurich, } \\
\text { Switzerland }\end{array}$ \\
\hline Water bath & 1003 & GFL/ Burgwedel, Germany \\
\hline X-ray films & HyperfilmTM & $\begin{array}{l}\text { Amersham Biosciences } \\
\text { /Freiburg, Germany }\end{array}$ \\
\hline
\end{tabular}

\subsection{Kits}

All the listed kits were used according to the manufacturer's instructions.

Table 5 list of the kits used in this study

\begin{tabular}{llll}
\hline Name & $\begin{array}{l}\text { Company/ Cat. } \\
\text { No. }\end{array}$ & Application \\
\hline $\begin{array}{l}\text { Caspase-3 activity assay kit } \\
\begin{array}{l}\text { C-terminus One-STrEP-tag } \\
\text { detection kit }\end{array}\end{array}$ & AP & IBA/2-1503-000 & $\begin{array}{l}\text { Apoptotic activity assay } \\
\text { C-Terminus Onged protein detection }\end{array}$
\end{tabular}


C-terminus One-STrEP-tag Starter IBA/2-1101-000 kit

EndoFree Plasmid Maxi Kit

QIAfilter Plasmid Midi Kit

Qiaprep Spin Miniprep Kit

QIAquick gel extraction Kit

QIAquick PCR purification Kit

StarGate Transfer / combinatorial IBA/5-1603-020 Cloning kit
Purification of C-Terminus One-STrEP-tag protein

Qiagen/12362

Qiagen/12243

Qiagen/27106

Qiagen/28704

Qiagen/28106

Plasmid DNA preparation

Plasmid DNA preparation

Plasmid DNA preparation

DNA gel extraction

DNA fragment purification

Cloning of C-Terminus OneSTrEP-tag plasmids

\subsection{Oligonucleotids}

The oligonucleotides used in this study are listed in Table 6

Table 6 List of oligonucleotides

\begin{tabular}{llc}
\hline Oligo & Sequence (5'-3') & Accession/Cat. No. \\
\hline Prnp-For & AATGGCGAACTTGGCTGCTGGAT & DQ408531 \\
Prnp-Rev & TCCCACTATCAGGAAGATGAGGAA & DQ408531 \\
Prnp-M129v-For & CACATGGCTGATGCTGCAGCAG & DQ408531 \\
Prnp-M129v-Rev & GTGTACCGACTACGACGTCGTC & DQ408531 \\
Prnp-H169y-For & CCATGGATGAGCACAGCAACCAG & DQ408531 \\
Prnp-H169y-Rev & GGTACCTACTCGTGTCGTTGGTC & DQ408531 \\
$\begin{array}{l}\text { Pesg-sequencing- } \\
\text { Primer-For }\end{array}$ & GAGAACCCACTGCTTACTGGC & IBA/5-0000-121 \\
$\begin{array}{l}\text { Pesg-sequencing- } \\
\text { Primer-Rev }\end{array}$ & TAGAAGGCACAGTCGAGG & IBA/5-0000-122 \\
siRNA Duplex & & \\
siRNA-Rab7a & CUGCUGCGUUCUCCUAUUU & Operon \\
siRNA Negative control & & EUROGENTES/SR- \\
& & CL000-005 \\
\hline Note: Colour highlights the combinatorial sites for combinatorial cloning (see section \\
3.2.2).
\end{tabular}




\subsection{Plasmids}

pENTRY- IBA1 (Lot. No. 4095-) and pESG-IBA103 (Cat. No. 5-4503-000) plasmids were provided by IBA, Goettingen. The construct maps for these vectors are provided in the Appendix.

\subsection{Software}

The following is a list of scientific software used in the study.

Table 7 List of scientific software

\begin{tabular}{|c|c|c|}
\hline Program & Use & References \\
\hline Decodon Delta2D & 2-DE gel analysis & $\begin{array}{lll}\text { DECODON } & \text { GmbH, } & \text { Greifswald } \\
\text { Germany } & & \end{array}$ \\
\hline Graphpad Prism 5 & Statistical analysis & $\begin{array}{l}\text { GraphPad Software, Inc. California, } \\
\text { USA }\end{array}$ \\
\hline ImageJ $1.43 u$ & Densitomatric analysis & National institutes of Health, USA \\
\hline ImageJ 1.43u WCIF & Colocalization analysis & National institutes of Health, USA \\
\hline KC4 V3.4 & Absorbance reader & Bioteck instruments, USA \\
\hline Lablmage 2.7.1 & Densitomatric analysis & Kapelan GmbH, Halle, Germany \\
\hline $\begin{array}{l}\text { Protein-Lynx-Global- } \\
\text { Server v } 2.1\end{array}$ & $\begin{array}{l}\text { LS MS/MS data } \\
\text { analyzer }\end{array}$ & Micromass, Manchester, U.K \\
\hline Zeiss LSM 4.2.0.121 & Immunofluorescence & $\begin{array}{l}\text { Microlmaging GmbH, Goettingen, } \\
\text { Germany }\end{array}$ \\
\hline
\end{tabular}

\subsection{Stock solutions}

Blocking solution for WB: $5 \%$ Milk Powder in TBS-T

Cell lysis buffer I: $50 \mathrm{mM}$ Tris-HCl pH 8.0, 0.5\% CHAPS, 1mM EDTA, 1\% triton $\times 100$

Cell lysis buffer II: $7 \mathrm{M}$ urea, $2 \mathrm{M}$ thiourea, 4\% CHAPS, 2\% ampholytes, 1\% DTT and a protease inhibitor mixture

Electrophoresis buffer (SDS-running buffer): $192 \mathrm{mM}$ glycine, $0.1 \%$ SDS, $25 \mathrm{mM}$ Tris- $\mathrm{HCl} \mathrm{pH} 8.3$ 
Elution buffer (C-terminus One-STrEP-tag purification): $100 \mathrm{mM}$ Tris- $\mathrm{HCl} \mathrm{pH}$ 8.0, $150 \mathrm{mM} \mathrm{NaCl}, 1 \mathrm{mM}$ EDTA, $1 \%$ triton x100

Equilibration buffer I: $6 \mathrm{M}$ urea, 2\% SDS, 30\% glycerin, $0.375 \mathrm{M}$ Tris $\mathrm{pH} 8.8,2 \%(\mathrm{w} / \mathrm{v})$ DTT

Equlibration buffer II: $6 \mathrm{M}$ urea, $2 \%$ SDS, $30 \%$ glycerin, $0.375 \mathrm{M}$ Tris $\mathrm{pH} 8.8,2.5 \%$ $(w / v)$ IAA, BPB in traces

Laemmli Buffer (6x): $125 \mathrm{mM}$ tris-Cl, 4\% SDS, 20\% glycerol, 2\% mercatoethanol, $\mathrm{pH}$ 6.8

Rehydration buffer: $8 \mathrm{M}$ urea, $2.5 \mathrm{M}$ thiourea, 4\% CHAPS, $66 \mathrm{mM}$ DTT and 0.5\% ampholytes

Silver staining solutions:

Developing solution: $6 \% \mathrm{Na}_{2} \mathrm{CO}_{3}, 0.0185 \%$ formaldehyde, $16 \mu \mathrm{M} \mathrm{Na} \mathrm{S}_{2} \mathrm{O}_{3}$ in $\mathrm{ddH}_{2} \mathrm{O}$

Fixation solution: $50 \%$ methanol, $12 \%$ acetic acid in $\mathrm{ddH}_{2} \mathrm{O}$

Sensitizing solution: $0.8 \mathrm{mM} \mathrm{Na}_{2} \mathrm{~S}_{2} \mathrm{O}_{3}$ in $\mathrm{ddH}_{2} \mathrm{O}$

Silver nitrate solution: $\mathrm{AgNO}_{3} 0.2 \%$ and $0.026 \%$ formaldehyde in $\mathrm{dd}_{2} \mathrm{O}$

TBE: 42 mM Boric Acid, $10 \mathrm{mM}$ EDTA, 50 mM Tris-HCl pH 8.0

TBS-T: TBS and $0.1 \%$ of Tween-20

TE: $0.01 \mathrm{M}$ Tris-HCl, pH 7.4, 1 mM EDTA pH 8.0

Transblot buffer for Nitrocellulose membrane: $192 \mathrm{mM}$ glycine, 20\% methanol, 25 $\mathrm{mM}$ Tris- $\mathrm{HCl} \mathrm{pH} 8.3$

Transblot buffer for PVDF membrane (semi dry): $192 \mathrm{mM}$ Glycine, 10\% methanol, $25 \mathrm{mM}$ Tris- $\mathrm{HCl} \mathrm{pH} 8.3$ 


\section{Methods}

\subsection{Microbiological methods}

\subsubsection{Culturing and storage of E. coli}

The E. coli strains were cultured for about $12-16 \mathrm{H}$ in LB-medium at $37^{\circ} \mathrm{C}$ on an orbital shaker at $180-250 \mathrm{rpm}$ until approximately $0.6 \mathrm{OD}_{600}$. For long-term storage bacterial strains were mixed with glycerol $(9: 1)$ and stored at $-80^{\circ} \mathrm{C}$.

\subsubsection{Preparation of electrocompetent $E$. coli cells}

One liter of LB medium was inoculated with $10 \mathrm{ml}$ of fresh overnight culture of E.coli (DH5a strain). The culture was incubated for about 12-16 $\mathrm{H}$ in LB-medium at $37^{\circ} \mathrm{C}$ on an orbital shaker at $180-250 \mathrm{rpm}$ until the $\mathrm{OD}_{600}$ reached to approximately 0.5 0.8 . The culture was cooled on ice for $1 \mathrm{H}$ and centrifuged at $5,000 \times \mathrm{g}$ for $10 \mathrm{~min}$. at $4^{\circ} \mathrm{C}$. The pellet was resuspended in $10 \mathrm{ml}$ ice-cold $\mathrm{ddH}_{2} \mathrm{O}$ and centrifuged at $5,000 \mathrm{x} \mathrm{g}$ for $15 \mathrm{~min}$. at $4^{\circ} \mathrm{C}$. The resuspension and centrifugation step was repeated as before. The pellet was then resuspended in $5 \mathrm{ml}$ ice-cold $\mathrm{ddH}_{2} \mathrm{O}$. After centrifugation at $5,000 \mathrm{x}$ $\mathrm{g}$ for $15 \mathrm{~min}$. at $4^{\circ} \mathrm{C}$, the bacterial pellet was resuspended in $30 \mathrm{ml}$ ice-cold $\mathrm{ddH}_{2} \mathrm{O}$ with a final concentration of $10 \%$ glycerol. Following the last centrifugation step $(5,000 \times \mathrm{g}$ for $15 \mathrm{~min}$. at $4^{\circ} \mathrm{C}$ ), the pellet was then resuspended in ice-cold $\mathrm{ddH}_{2} \mathrm{O}$ followed by slow addition of glycerol to a final concentration of $10 \%$. This cell suspension was dispensed in $0.5 \mathrm{ml}$ aliquots which were first subjected to shock freezing in liquid $\mathrm{N}_{2}$ before storage at $-80^{\circ} \mathrm{C}$. Cells were kept on ice during the entire procedure.

\subsubsection{Transformation of electrocompetent E. coli with plasmid DNA}

An aliquot of competent cells was first allowed to thaw on ice. About 5 ng DNA ligation product was added to $50 \mu \mathrm{l}$ of competent cells and incubated for $5 \mathrm{~min}$. The mixture was then subjected to electroporation pulse using Bio-Rad Gene Pulser II (BioRad, München, Germany). Electroporation was carried out at $1.8 \mathrm{kV}$ with capacitance of $25 \mu \mathrm{F}$ and pulse-controller-resistance of $200 \Omega$. Immediately after the pulse, $900 \mu \mathrm{l}$ of pre-warmed LB medium was added to the cuvette. After resuspension cells were incubated for $40 \mathrm{~min}$. at $37^{\circ} \mathrm{C}$ with shaking $(180 \mathrm{rpm})$. The transformed cells were then 
plated on pre-warmed LB agar supplemented with $100 \mu \mathrm{g} / \mathrm{ml}$ ampicillin and $50 \mu \mathrm{g} / \mathrm{ml} \mathrm{X-}$ $\mathrm{Gal}$, or $50 \mu \mathrm{g} / \mathrm{ml} \mathrm{Kanamycin} \mathrm{and} \mathrm{then} \mathrm{incubated} \mathrm{at} 37^{\circ} \mathrm{C}$ for $12-16 \mathrm{H}$.

\subsubsection{Extraction of plasmid DNA}

Plasmid DNA was extracted using the QIAPrep Spin Miniprep Kit (QIAGEN, Hilden, Germany). A single colony of $E$. coli was inoculated into $5 \mathrm{ml}$ LB medium supplemented with ampicillin to a final concentration of $100 \mu \mathrm{g} / \mathrm{ml}$ and then incubated for $16 \mathrm{H}$ at $37^{\circ} \mathrm{C}$ with shaking (180 rpm). The cells were harvested by centrifugation at $5,000 \times \mathrm{g}$ for $10 \mathrm{~min}$. at $4^{\circ} \mathrm{C}$. The remaining steps were performed according the manufacturer's instructions.

\subsection{Molecular biology methods}

\subsubsection{Extraction of genomic DNA}

A total of $500 \mu \mathrm{l}$ fresh anticoagulated/EDTA whole human blood was supplemented with RNase A (100 mg/ml) to obtain RNA-free genomic DNA. The blood cells were then lysed in $1 \mathrm{ml}$ of lysis buffer, briefly mixed by vortexing, and then incubated for $10 \mathrm{~min}$. at $56^{\circ} \mathrm{C}$ followed by the addition of $200 \mu \mathrm{l}$ of $100 \%$ ethanol and brief vortexing. The mixture was then carefully applied to a QIAamp spin column and centrifuged for one minute at approximately $11,000 \times \mathrm{g}$ in a table-top microcentrifuge. The bound DNA was washed with $500 \mu \mathrm{l}$ of washing buffer and the column was centrifuged for one minute. An additional washing step was carried out by applying 500 $\mu \mathrm{l}$ of washing buffer to the QIAamp spin column which was then centrifuged for $3 \mathrm{~min}$. at maximum speed $(13,000 \times \mathrm{g})$. Any residual contaminants were removed by another 1 min. centrifugation step. Finally, the QIAamp spin column was loaded with $200 \mu \mathrm{l}$ of elution buffer, incubated for $5 \mathrm{~min}$. at RT and centrifuged at approximately $11,000 \times \mathrm{g}$ for an additional minute. Small- and large-scale plasmid extractions were performed using the QIAGEN Mini and Maxi kits respectively according to the manufacturer's instructions.

Ethanol DNA precipitation was carried out in order to improve the purity of the eluted DNA. Two volumes of ice-cold $100 \%$ ethanol and one tenth volume of $3 \mathrm{M}$ sodium acetate buffer ( $\mathrm{pH} 5.0$ - 5.3) were added to one volume of eluted DNA. The solution was briefly vortexed and left on dry ice for 2-5 min. The supernatant was 
quickly discarded after centrifugation $(11,000 \times \mathrm{g})$ in a microcentrifuge for $30 \mathrm{~min}$. at $4^{\circ} \mathrm{C}$. Then $200 \mu \mathrm{l}$ of ice-cold $70 \%$ ethanol was added to the precipitate. Following another centrifugation step at maximum speed $(11,000 \times \mathrm{g})$ for $10 \mathrm{~min}$ at $4^{\circ} \mathrm{C}$, the supernatant was discarded and any residual ethanol was carefully removed without disturbing the pellet. The pellet was then air-dried for 2-3 min. and subsequently resuspended in TE buffer ( $\mathrm{pH}$ 8.0). The solution was briefly mixed by vortexing, shortly centrifuged $(13,000 \times \mathrm{g})$ and stored at $4^{\circ} \mathrm{C}$ for further analysis.

\subsubsection{Combinatorial cloning procedures}

All the procedures were performed according to the instructions provided in the StarGate Transfer/combinatorial Cloning kit-IBA with a slight modification, briefly described (below);

\subsubsection{Primer design}

The 5'- phosphorylated primers for combinatorial cloning (see section 2.8) were equipped with combinatorial sites at the $5^{\prime}$ - and $3^{\prime}$ - ends with the initial hybridization region having a melting temperature of $60-63^{\circ} \mathrm{C}$. The $3^{\prime}-$ end of the primers was designed to be phosphorothioate protected with a proof reading DNA polymerase. The 5'- ends of the standard forward primers were formed by an additional -AATGquadruplet to generate the upstream combinatorial site. The 3'- ends of the standard reverse primers were formed by an additional -TCCC- quadruplet to generate the downstream combinatorial site.

\subsubsection{Amplification of PRNP}

The amplification of PRNP was carried out in a total volume of $50 \mu \mathrm{l}$ containing 2 $\mathrm{mM} \mathrm{MgSO}_{4}, 10 x$ ThermoPol Reaction buffer (New England Biolabs), $20 \mathrm{mM}$ dNTPs (New England Biolabs), 25 pmol of each oligonucleotide primer, 1 U DNA polymerase $(2,000 \mathrm{U} / \mathrm{ml})$ (New England Biolabs), $100 \mathrm{ng}$ of the template DNA and $\mathrm{ddH}_{2} 0$. Thirty-five cycles were done with initial denaturation at $95^{\circ} \mathrm{C}$ for $120 \mathrm{~s}$, denaturation at $95^{\circ} \mathrm{C}$ for 30 $\mathrm{s}$, annealing at $60^{\circ} \mathrm{C}$ for $45 \mathrm{~s}$ and extension at $72^{\circ} \mathrm{C}$ for $60 \mathrm{~s}$.

\subsubsection{Donor vector generation}

The pENTRY-IBA1 entry vector was mixed with $4 \mathrm{nM}$ of water diluted PCR product and Star Solution $\mathrm{E}(1 \mu \mathrm{l})$, then incubated for $1 \mathrm{H}$ at $22^{\circ} \mathrm{C}$. An aliquot of $10 \mu \mathrm{l}$ from the reaction mixture was incubated for $30 \mathrm{~min}$. on ice with competent cells. The 
mixture was mixed gently and incubated for $5 \mathrm{~min}$. at $37^{\circ} \mathrm{C}$ and subsequently on ice for 2-5 min. Then the mixture was supplemented with $900 \mu \mathrm{L}$ LB medium (without antibiotics) and incubated at $37^{\circ} \mathrm{C}$ with shaking for $45 \mathrm{~min}$. The mixture was then plated on pre warmed LB Agar containing $50 \mathrm{mg} / \mathrm{L}$ kanamycin and incubated at $37^{\circ} \mathrm{C}$ for $12-16$ $\mathrm{H}$.

\subsubsection{Mammalian expression vector generation}

The supplied lyophilized, liquid acceptor vector pESG-IBA103 was diluted with generated donor vector solution to make the final concentration $1 \mathrm{ng} / \mu \mathrm{l}$. Star solution A1, A2, A3 (1 $\mu \mathrm{l}$ each) were added and incubated with the StarMixll at $30^{\circ} \mathrm{C}$ for $1 \mathrm{H}$. The generated vectors were then transformed in competent cells previously thawed on ice. The mixture was mixed gently and incubated on ice for $30 \mathrm{~min}$, then incubated at $37^{\circ} \mathrm{C}$ for 5 min., and finally put on ice for $2 \mathrm{~min}$. The mixture was then supplemented with 90 $\mu \mathrm{LB}$ medium (without antibiotics), plated on LB Agar containing $100 \mathrm{mg} / \mathrm{L}$ ampicillin and $50 \mathrm{mg} / \mathrm{L} \mathrm{X}-\mathrm{Gal}$, and finally incubated at $37^{\circ} \mathrm{C}$ for $12-16 \mathrm{H}$. The generated vectors were then extracted as mentioned previously in section 3.1.4.

\subsubsection{Restriction digestion of vector DNA}

For cloning and analytical confirmation of the resultant clones, DNA was digested using Xba1/HindIII restriction enzymes (FERMENTAS, St.Leon-Rot, Germany, New England Biolabs, Frankfurt, Germany). Generally 5-10 $\mu \mathrm{g}$ of plasmid DNA was digested for $1-2 \mathrm{H}$ in a total volume of $20 \mu \mathrm{l}$ at $37^{\circ} \mathrm{C}$ using appropriate endonucleases in corresponding buffers. Three white colonies were selected and DNA mini preparation was performed (see section 3.1.4).

\subsubsection{Site directed mutagenesis}

Site directed mutagenesis was used to generate mutations (base substitutions) from double-stranded plasmid without the need for subcloning. The cDNA (0.5 pmole) was added to a PCR cocktail containing, $2 \mathrm{mM} \mathrm{MgSO}_{4}$ buffer, $0.2 \mathrm{mM}$ of each dNTP, 25 pmol of each oligonucleotide primer, $2.5 \mathrm{U}$ Taq/Pfu DNA polymerase mix and 5\% DMSO. Twenty-five cycles were performed with initial denaturation at $95^{\circ} \mathrm{C}$ for $120 \mathrm{~s}$, denaturation at $95^{\circ} \mathrm{C}$ for $30 \mathrm{~s}$, annealing at $60^{\circ} \mathrm{C}$ for $30 \mathrm{~s}$ and extension at $72^{\circ} \mathrm{C}$ for $60 \mathrm{~s}$ with a final extension of one cycle at $72^{\circ} \mathrm{C}$ for $120 \mathrm{~s}$. The parental template DNA and the linear, mutagenesis-primer incorporating newly synthesized DNA were treated with DpnI 
(15 U) and $D p n /$ buffer $5 \mu / / 50 \mu l$. The $D p n l$ enzyme is specific for methylated and hemimethylated DNA and therefore digests the parental DNA template but does not digest the mutant synthesized DNA. As most E.coli strains produce methylated DNA, they are not resistant to $D p n /$ digestion. This reaction was incubated at $37^{\circ} \mathrm{C}$ for $2 \mathrm{H}$. Undigested DNA was then purified by the PCR purification kit according to the manufacturer's instructions. The purified mutated DNA was then transformed into competent cells (see 3.1.3).

\subsubsection{DNA agarose gel electrophoresis}

Agarose was melted in TBE buffer and $0.3 \mu \mathrm{g} / \mathrm{ml}$ ethidium bromide solution was added after being cooled to RT. The agarose was then poured into the agarose gel chamber. DNA samples were mixed with DNA loading buffer and $\mathrm{dd}_{2} \mathrm{O}$ up to a final volume of $12.5 \mu \mathrm{l}$ for loading of the gel. Gels were run in $1 \times$ TBE buffer at 80-100 V for 1-2 $\mathrm{H}$, depending on the size of the examined DNA fragment or on the degree of the band separation required. The DNA bands were then visualized by UV light at $302 \mathrm{~nm}$ using a Gel Documentation 2000тм UVtransilluminator (Bio-Rad) and the Quantity One software (version 4.2.1). The estimation of DNA was done by visual comparison of the band intensity with that of a standard marker.

\subsubsection{Purification of DNA from agarose gels}

The PCR products were purified using QIAquick gel extraction Kits. The DNA fragments (bands) were excised from the agarose gels. The remaining steps were done exactly as described in the manufacturers instructions provided. The concentration of DNA in the final solution was measured at the Biophotometer (Eppendorf) at $260 \mathrm{~nm}$.

\subsection{Cell biology methods}

\subsubsection{Cryopreservation and thawing of eukaryotic cells}

For long-term storage, cells were frozen in the presence of dimethylsulphoxide (DMSO). The $60-90 \%$ confluent cells were centrifuged at $400 \times \mathrm{g}$ for 5 minutes at $4^{\circ} \mathrm{C}$. The cells were then resuspended in ice-cold medium containing 70\% DMEM, 20\% FBS and $10 \%$ DMSO and finally aliquoted into $1 \mathrm{ml}$ cryogenic storage vials. The storage vials 
were incubated at $-20^{\circ} \mathrm{C}$ for $5 \mathrm{H}$ and then $12-16 \mathrm{H}$ at $-80^{\circ} \mathrm{C}$ before they were finally stored in cryogenic vials suspended in liquid nitrogen.

To re-freeze the cryo-preserved cells, the cryogenic stored vials with cells were quickly thawed in a water bath at $37^{\circ} \mathrm{C}$. Subsequently, the cells were directly mixed with complete culture media (see section 2.5) and centrifuged at $400 \mathrm{x} \mathrm{g}$ for $5 \mathrm{~min}$. in order to remove the cryopreservative (DMSO). The cells were then resuspended in the complete culture media and seeded in tissue culture flasks.

\subsubsection{Cultivation of eukaryotic cells}

All cell lines were cultured in their respective media (see section 2.5) and underwent between 5 and 25 passages. The cells were diluted 1:4 every 3-5 days after reaching approximately $70 \%$ confluency. The cell medium was removed and $3-5 \mathrm{ml}$ of pre-warmed $\left(37^{\circ} \mathrm{C}\right) \quad 0.05 \%$ trypsin/0.02\% EDTA solution was added to the culture, incubated for $2-5 \mathrm{~min}$. until the cells detached from the flask at $37^{\circ} \mathrm{C}$. Cell culture medium $(10 \mathrm{ml})$ was then added to stop the trypsin activity. The detached cells were carefully transferred to a Falcon tube and were spun down at $4^{\circ} \mathrm{C}$ for 5 minute at $400 \mathrm{x}$ g. After removing the supernatant the cell pellet was resuspended in $10 \mathrm{ml}$ fresh media and seeded in four flasks $\left(75 \mathrm{~cm}^{2}\right)$. In the case of neuronal SH-SY5Y (PrPC Stable expressed) cells, Geniticin $200 \mu \mathrm{g} / \mathrm{ml}$ containing media in $75 \mathrm{~cm}^{2}$ flasks was used for selection.

\subsubsection{Liposome-mediated transient transfection}

Transfection assays were performed using Lipofectamine 2000 (Invitrogen) following the supplier's recommendations. The cells were seeded in 6-well plates at a cell density of $2-5 \times 10^{5}$ per well and maintained for $24 \mathrm{H}$ in the medium containing $10 \%$ FBS. Prior to transfection cells were washed with Opti-MEM ${ }_{\circledast} I$ and subsequently transfected with $5 \mu \mathrm{g}$ of DNA/well in Opti-MEM® ${ } \mathrm{I}$. After an incubation period of $24 \mathrm{H}$ the transfection medium was replaced with DMEM supplemented complete medium. Cells were collected from confluent cultures after $48 \mathrm{H}$ of transfection.

\subsubsection{Small interference RNAi treatment}

The cells were cultured (see section 3.3.2) for $24 \mathrm{H}$ in complete DMEM medium prior to transient transfection (see section 3.3.3). The C-Terminus One-STrEP-tag PrPC $(5 \mu \mathrm{g})$ was co-transfected with siRNA (100 nM) (see section 2.8) in HpL3-4 cells. In SH- 
SY5Y siRNAs with $100 \mathrm{nM}$ duplexes were transfected using Lipofectamine 2000 (Invitrogen, Carlsbad, CA, USA) according to the manufacturer's instructions. The cells were also simultaneously transfected with non-targeting siRNA duplex (control siRNA Duplex Negative Control: Eurogentec). After $48 \mathrm{H}$ of transfection the cells were lysed (see section 3.3.7) for expression analysis and immunofluorescence (see section 3.3.6) for localization studies.

\subsubsection{Immunocytochemical and quantification analysis}

Cells were plated on chambered slides (Lab-Tek ${ }^{\mathrm{TM}}$ II; Thermo Fisher Scientific (Nunc GmbH \& Co. KG), Langenselbold Site) and transfected with the C-terminus OneSTrEP-tag $\operatorname{PrP}^{\mathrm{C}}$ for 24,36 , and $48 \mathrm{H}$. Cells were subsequently washed in a phosphatebuffered saline (PBS) and were fixed for $15 \mathrm{~min}$. with $100 \%$ ethanol. After fixation cells were permeabilised with $0.2 \%$ Triton X-100 in $1 x P B S$, followed by a 20 min. blocking step using $0.2 \%$ casein-solution containing Tween 20. Co-localization of $\mathrm{PrP}^{\mathrm{C}}$ with interacting proteins was detected by applying the primary antibodies [anti-PrP 3F4 (1:200), rabbit anti-Rab7a (1:50), rabbit anti-Rab9 (1:50), mouse anti-Arf (1:500), and mouse anti-Tubulin alpha $(1: 100)]$ for $12-14 \mathrm{H}$ at $4^{\circ} \mathrm{C}$. The primary antibodies were detected by incubating the slides for $60 \mathrm{~min}$ with secondary antibodies [Alexa 488 conjugated anti-rabbit (1:200), Alexa 488 conjugated anti-mouse (1:200) or Cy3-labeled anti-mouse secondary antibody (1:200)]. Incubation with Hoechst 33342 or with TOPRO-3 iodide for 10 min was performed to visualize nuclei. Finally, cover slips were placed on glass slides and mounted with Fluoromount (DAKO, Hamburg, Germany). After secondary antibody incubation all the steps were carried out in a dark humid chamber. The slides were kept dry in dark at $4^{\circ} \mathrm{C}$ until further microscopic evaluation.

Confocal laser scanning microscopy was carried out using a LSM 510 laserscanning microscope (Zeiss, Göttingen, Germany; 488 nm Argon, 543 and 633 nm Helium-Neon excitation wavelengths) according to the manufacturer's instructions for the localization of $\operatorname{PrP}^{\mathrm{C}}$ and other interacting proteins, using a 63x/1.25 oil immersion lens. Individual images were analyzed separately for colocalization using LSM 5 (Zeiss) or ImageJ (WCIF plugin) software. For two-color analysis, stacks of images with a total thickness of approximately $30 \mu \mathrm{m}$ were acquired, using a dynamic range of 12 bits per pixel. Colocalization expressed as a correlation coefficient indicates the strength and direction of the linear relationship between two fluorescence channels. Pearson's linear 
correlation coefficient $\left(r_{\mathrm{P}}\right)$ was used in this study to calculate fluorescence channel correlations:

$$
r_{\mathrm{p}}=\sum_{i}\left(x_{i}-x_{\text {aver }}\right) \cdot\left(y_{i}-y_{\text {aver }}\right) /\left(\sum_{i}\left(x_{i}-x_{\text {aver }}\right)^{2} \cdot\left(y_{i}-y_{\text {aver }}\right)^{2}\right)^{1 / 2}
$$

Where $x_{i}=$ intensity of voxel $I$ in image $\left(x_{i}=0\right.$ if $x_{i}$ is outside threshold of detection)

$y_{i}=$ intensity of voxel $/$ in image $\left(y_{i}=0\right.$ if $y_{i}$ is outside threshold of detection)

$x_{\text {aver }}$ and $y_{\text {aver }}$ represent averages of the $x$ and $y$ channel intensities.

The value of $r_{\mathrm{p}}$ is between -1 and 1 , where 0 indicates no correlation, and -1 indicates negative correlation. Values $>0$ indicate a positive correlation.

Colocalization in the context of fluorescence microscopy is defined as the signal detection of two separated fluorescence channels at the same pixel. Threshold settings were generated automatically from regions of interest. Colocalization coefficients were calculated according to published methodology [Manders et al. 1993] in which

$$
\text { Colocalization coefficient }\left(\mathrm{M}_{x}\right)=\sum_{i} x_{i, \text { coloc }} / \sum_{i} x_{i}
$$

and

$$
\text { Colocalization coefficient }\left(\mathrm{M}_{\mathrm{y}}\right)=\sum_{i} y_{i, \text { coloc }} / \sum_{i} y_{i}
$$

Where $x_{i, \text { coloc }}=x_{i}$ if $y_{i}$ is within the intensity range defined by region of interest

$x_{i, \text { coloc }}=0$ if $y_{i}$ is outside the intensity range and

$y_{i, \text { coloc }}=y_{i}$ if $x_{i}$ is within the intensity range defined by region of interest

$y_{i, \text { coloc }}=0$ if $x_{i}$ is outside the intensity range.

Values of colocalization coefficients range between 0 and 1. A value of 0 indicates that none of the signal within thresholds in that channel exists as co-localized with the other channel. A value of 1 indicates that the entire signal within thresholds in that channel exists as colocalized with the other channel. Two perfectly colocalized images will generate a scatter plot where the points fall in a line at $45^{\circ}$ to either axis. 


\subsubsection{Cell lysis and protein extraction}

Total cell lysate was prepared from 70\% confluent HpL3-4, HEK-293 and SHSY5Y cells. For C-Terminus One-STrEP-tag purification, HpL3-4 cells after $48 \mathrm{H}$ of transient transfection were washed with ice cold $1 \times \mathrm{PBS}$, scraped and centrifuged at $4^{\circ} \mathrm{C}$ for $5 \mathrm{~min}$ at $400 \times \mathrm{g}$. The pellet was resuspended in ice cold 1x PBS and centrifuged at $4^{\circ} \mathrm{C}$ for $5 \mathrm{~min}$ at $400 \times \mathrm{g}$. The washed cells were then lysed in lysis buffer I (50 mM Tris$\mathrm{HCl}, \mathrm{pH} 8,1 \%$ Triton X-100, 0.5\% CHAPS, $1 \mathrm{mM}$ DTT, Roche protease and phosphatase inhibitor cocktail). Cell lysates were homogenized with an ultra sonicator on ice (5 strokes) and were then ultra-centrifuged for $15 \mathrm{~min}$. with $543,000 \times \mathrm{g}$ at $4^{\circ} \mathrm{C}$. Protein concentration was estimated (see section 3.3.8) and either underwent further CTerminus One-STrEP-tag purification or was stored at $-20^{\circ} \mathrm{C}$.

\subsubsection{Determination of protein concentration}

The protein concentration of cell lysate was determined by the Bradford assay (Bio-Rad). Working solution was prepared by diluting a dye reagent (Bio-Rad) with $\mathrm{dH}_{2} \mathrm{O}$ 1:5 followed by filtration through Whatmann filter paper. BSA protein standards were prepared in $\mathrm{dH}_{2} \mathrm{O}$ with a concentration range between $0.0-1.0 \mathrm{mg} / \mathrm{ml}$. Protein samples of unknown concentration were diluted 1:5, 1:10 and 1:20. Protein standards or diluted samples of unknown concentrations $(20 \mu \mathrm{l})$ were mixed with $1 \mathrm{ml}$ of Bradford working solution and incubated for $10 \mathrm{~min}$. at RT. The absorbance of the samples was measured at $595 \mathrm{~nm}$. The calculation of the protein concentration was done using Microsoft Office 2007 Excel software.

\subsubsection{One-STrEP-tag purification}

Total cell lysate was first prepared (see section 3.3.7). The STrEP-Tactin superflow beads were equilibrated by $3 x$ washing with buffer containing $100 \mathrm{mM}$ Tris- $\mathrm{HCl}, \mathrm{pH} 8,1 \%$ Triton X-100, $1 \mathrm{mM}$ DTT, $150 \mathrm{mM} \mathrm{NaCl}$, Roche protease and phosphatase inhibitor cocktail. The total amount of protein isolated was estimated and then the beads were diluted with wash buffer containing $100 \mathrm{mM}$ Tris- $\mathrm{HCl}$, pH8, 1\% Triton X-100, 1mM DTT, Protease and Phosphatase inhibitors to make the final concentration of CHAPS $0.1 \%$. The equilibrated STrEP-Tactin superflow beads were incubated with $4 \mathrm{mg}$ total protein for $1 \mathrm{H}$ at $4^{\circ} \mathrm{C}$ on a rocking platform. Following the centrifugation at 15,000 rpm for 2 min. at $4^{\circ} \mathrm{C}$ supernatant was removed and STrEP-Tactin superflow beads with attached STrEP-tag protein were washed $4 \mathrm{x}$ with wash buffer and then STrEP-tagged protein 
complex was eluted with $2.5 \mathrm{mM}$ Desthiobiotin. The eluted proteins were precipitated with methanol/chloroform [Wessel and Flugge 1984].

\subsubsection{Immunoprecipitation}

Cell lysis was performed as described previously (section 3.3.5). The insoluble cell debris was removed by centrifugation at $543,000 \mathrm{xg}$ for $10 \mathrm{~min}$. at $4^{\circ} \mathrm{C}$. Immunoprecipitation was performed using Dynabeads protein $\mathrm{G}(1.5 \mathrm{mg}$ beads $/ 3 \mathrm{mg}$ total protein) according to the manufacturer's instructions. Samples of total cytoplasmic cell extracts or immunoprecipitated proteins (corresponding to $2 \times 10^{6} \mathrm{cells} / \mathrm{lane}$ ) were subjected to $12.5 \%$ SDS-PAGE and transferred to polyvinylidene difluoride membranes (Millipore). Immunoblotting was performed as described in section 3.3.12.

\subsubsection{SDS-PAGE}

Two-phase gels were used for stacking and separating the proteins of interest according to their molecular weight (4\% stacking gel and $12.5 \%$ resolving gel). Molecular weight markers were run in parallel in order to determine the size of the loaded proteins. Equal amounts of protein samples and 2x sample buffer (see section 2.9) were mixed, heated for $10 \mathrm{~min}$. at $95^{\circ} \mathrm{C}$ and loaded onto the gel. SDS-PAGE was run at $4^{\circ} \mathrm{C}$. A voltage of $20 \mathrm{~mA}$ was applied for $15 \mathrm{~min}$. to allow samples to enter the gel and stack without smearing and then increased to $40 \mathrm{~mA}$ until bromphenol blue reached the bottom of resolving gel.

\subsubsection{Immunoblot analysis}

Cells were lysed $(50 \mathrm{mM}$ Tris- $\mathrm{HCl}, \mathrm{pH} 8,1 \%$ Triton X-100, 0.5\% CHAPS, $1 \mathrm{mM}$ DTT), and lysates were cleared off from cellular debris ( 1 minute, $1000 \times g, 4^{\circ} \mathrm{C}$ ). Cell lysates were supplemented with Roche protease and phosphatase inhibitor and were separated on 12.5\% SDS-PAGE (see section 3.3.11). Expression of proteins was analyzed by western blot using anti-PrP $6 \mathrm{H} 4$ monoclonal antibody (1:1000), anti-PrP SAF70 monoclonal antibody (1:5000), anti-Rab7a mAb (1:1000), anti-Arf1 mAb (1:1000) and anti-Tubulin alpha (1:5000) for $12-14 \mathrm{H}$ at $4^{\circ} \mathrm{C}$. Membranes were then rinsed in $1 \mathrm{x}$ TBS-T and incubated with the corresponding horseradish peroxidase-conjugated secondary antibody (diluted 1:2000/1:5000) for $1 \mathrm{H}$ at RT. Immunoreactivity was detected after immersion of the membranes into enhanced chemiluminescence (ECL) solution and exposure to ECL-Hyperfilm (Amersham Biosciences, Buckinghamshire, 
U.K.). Densitometric values for each band intensity were determined using lab image 2.7.1 data analyzer software.

\subsubsection{Two-dimensional gel electrophoresis First dimension electrophoresis}

Proteins were separated in the first dimension by isoelectric focusing (IEF), which separates proteins by their isoelectric point (pl). Seven centimeter pre-cast immobilized $\mathrm{pH}$ gradient (IPG) strips (ReadyStrip IPG, Bio Rad) with a linear pH range between 3-10 were used. The amount of protein loaded on each IPG strip varied with the staining method and the length of the strip. The protein load for Coomassie staining was $200 \mu \mathrm{g}$ whereas for silver staining it was $40 \mu \mathrm{g}$. The cell lysates were prepared as described in Section 3.3.7. The total volume of sample applied per IPG strip was 130-135 $\mu$ l for each $7 \mathrm{~cm}$ IPG strip.

Rehydration of IPG strips was carried out in the re-swelling cassette (Bio-Rad). The sample (130-135 $\mu \mathrm{l})$ containing a certain amount of protein was carefully applied onto the cassette track for strip rehydration. The protective film was removed from the IPG strips and placed (gel side down) onto the cassette without air bubbles. Following 1 $\mathrm{H}$ incubation at RT the IPG strips were overlaid with mineral oil (Bio-Rad) to avoid evaporation during an overnight passive rehydration (without any electric field). The focusing of the proteins on IPG strip was initiated at $200 \mathrm{~V}$ for $2 \mathrm{H}$, followed by ramping at $500 \mathrm{~V}$ for $2 \mathrm{H}$, and final focusing at $4000 \mathrm{~V}$ for $5 \mathrm{H}$ until a total of $20000 \mathrm{Vh}$ was achieved.

Prior to the second dimension electrophoresis an equilibration step was applied to the proteins separated by IEF in order to reduce disulfide bonds and to alkylate the resultant sulfhydryl groups of the cysteine residues. The IPG strips were incubated on a horizontal shaker with equilibration buffer I for $25 \mathrm{~min}$. followed by incubation in equlibration buffer II for a further $25 \mathrm{~min}$.

\section{Second dimension electrophoresis by SDS-PAGE}

Equilibrated strips were placed on top of vertical 12\% SDS polyacrylamide gels and overlaid with $1 \%(\mathrm{w} / \mathrm{v})$ agarose in SDS running buffer. The gels were loaded with the suitable protein markers and run at $100 \mathrm{~V}$ for $2 \mathrm{H}$ in Mini Protean II TM gel chamber 
at $4^{\circ} \mathrm{C}$. At the end of second dimension electrophoresis gels were removed from the glass plates and either Coomassie stained; silver stained and western blotted to PVDF membranes.

\section{Visualization and imaging of the gels}

Coomassie staining was carried out using Roti-Blue staining solution (Roth) mixed with ethanol and water in 40:20:40 ratios. The gels were then briefly destained using ethanol/acetic acid/water (20:5:75) after 12-14 $\mathrm{H}$ of incubation and stored in 5\% acetic acid in $d_{d d H_{2}} \mathrm{O}$. Sensitivity of detection by Coomassie staining requires approximately $40 \mathrm{ng}$ of protein per spot for detection and allows visualization of the broadest spectrum of proteins. The gels were silver stained using the protocol described by Blum and co-workers (1987).

\subsubsection{Protein/peptide sequence identification by LC/MS-MS}

\subsubsection{In-gel digestion and preparation of proteins and proteolytic fragments}

In-gel digestion was carried out according to the previously described protocol [Asif et al. 2007;Asif and Yevzlin 2009]. Specific bands were excised from the silverstained 1-DE gel into 1-2 $\mathrm{mm}^{2}$ slices, destained with $15 \mathrm{mM}$ potassium ferricyanide/50 $\mathrm{mM}$ sodium thiosulfate (Aldrich/Sigma-Aldrich, Steinheim, Germany) and then equilibrated with $50 \mathrm{mM}$ ammonium bicarbonate/50\% acetonitrile (ACN) (Sigma-Aldrich) until destained. Samples were dried for 15 min. using the SpeedVac SVC100 (Savant Instruments, Farmingdale, NY) vacuum concentrator. The dried slices were rehydrated with $10 \mathrm{mM}$ dithiothreitol $/ 100 \mathrm{mM}$ ammonium bicarbonate and incubated at $56^{\circ} \mathrm{C}$ for 45 min. The slices were then incubated with $55 \mathrm{mM}$ iodoacetamide/ $100 \mathrm{mM}$ ammonium bicarbonate at room temperature for $30 \mathrm{~min}$ in the dark and followed by washing with $100 \mathrm{mM}$ ammonium bicarbonate and made 1:1 solution with ACN and incubated for 15 min. Samples were dried for $15 \mathrm{~min}$. and rehydrated on ice with 10-20 $\mu \mathrm{L}$ of trypsin digestion $(0.1 \mu \mathrm{g} / \mu \mathrm{l})$ solution (Promega, Madison, WI) for $45 \mathrm{~min}$. followed by an overnight incubation at $37^{\circ} \mathrm{C}$ in digestion solution without trypsin. The peptides were first extracted with $0.1 \%$ trifluoracetic acid (TFA) for $30 \mathrm{~min}$. in a sonicating water bath Transsonic 310/H (Elma, Pforzheim, Germany) followed by extraction with 30\% ACN in $0.1 \%$ TFA and $60 \%$ ACN in $0.1 \%$ TFA. The eluate was collected in Eppendorf tubes 
and dried with the SpeedVac. The extracted peptides were dissolved in $0.1 \%$ formic acid (FA) for ESI-QTOF-MS/MS.

\subsubsection{Identification of protein/peptide sequence analysis}

One microliter of tryptic digested peptide solution was introduced using a CapLC auto sampler (Waters) onto a $\mu$-precolumn cartridge C18 pepMap (300 $\mu \mathrm{m} \times 5 \mathrm{~mm}$; 5 $\mu \mathrm{m}$ partical size) and further separated through a C18 pepMap100 nano Series (75 $\mu \mathrm{m}$ $\times 15 \mathrm{~cm} ; 3 \mu \mathrm{m}$ partical size) analytical column (LC Packings). The mobile phase consisted of solution $A(0.1 \% \mathrm{FA}$ in $5 \% \mathrm{ACN})$ and solution $\mathrm{B}(0.1 \% \mathrm{FA}$ in $95 \% \mathrm{ACN})$. The single sample run time was set for $60 \mathrm{~min}$. The chromatographically separated peptides were then analyzed on a Q-TOF Ultima Global (Micromass, Manchester, U.K.) mass spectrometer equipped with a nanoflow ESI Z-spray source in positive ion mode. Data acquisition was performed using MassLynx ( $v$ 4.0) software on a Windows NT PC and data were further processed on Protein-Lynx-Global-Server ( $v$ 2.1), (Micromass, Manchester, U.K.). Processed data were searched against MSDB and Swiss-Prot databases through the Mascot search engine using a peptide mass tolerance of $0.5 \mathrm{Da}$ and fragment mass tolerance of $0.5 \mathrm{Da}$. The search criteria were set to a maximum of one missed cleavage allowed by trypsin and protein modifications set to methionine oxidation and carbamidomethylcysteine when appropriate.

\subsubsection{Enzyme-linked immunosorbent assay (ELISA)}

For ELISA analysis the BetaPrion® BSE EIA Test Kit (Leipzig, Germany) was used and all procedures were performed according to the supplier's recommendations. Briefly, equal amounts of protein $(50 \mu \mathrm{g})$ from cell lysates of control and PRNPtransfected cells were added to a microtitre plate coated with a monoclonal anti-PrP antibody and incubated for $60 \mathrm{~min}$. at $37^{\circ} \mathrm{C}$. Recombinant human $\operatorname{PrP}^{\mathrm{C}}$ (Roboscreen, Leipzig, Germany) was used as a standard. After washing the plate three times a monoclonal, peroxidase-labeled, anti-PrP antibody was added followed by $60 \mathrm{~min}$. incubation at $4^{\circ} \mathrm{C}$. Following five more washes a microtitre plate was incubated for 15 min. with a developing solution containing hydrogen peroxide and tetramethylbenzidine. Afterwards the reaction was stopped, extinction measured (at 450/620 nm) and $\operatorname{PrP}^{C}$ concentration $(\mathrm{ng} / \mathrm{ml})$ was determined. Means and standard deviations were calculated from three independent sets of experiments. Significant differences in $\mathrm{PrP}^{\mathrm{C}}$ levels were 
determined using unpaired Student's $t$-test $(p<0.05)$. Each sample was run in duplicate in a blinded fashion.

\subsection{Biochemical methods}

\subsubsection{Cell viability assays}

The adherent cells were grown to $60-70 \%$ confluency and then detached from flasks using $1 \times$ Trypsin-EDTA. The cells were spun down at $4^{\circ} \mathrm{C}$ for $5 \mathrm{~min}$. at $400 \times \mathrm{g}$ and resuspended in culture media. Cells were then dispensed into 24-well plates (Nunc, Roskilde, Denmark) at a final concentration of $1 \times 10^{5}$ cells/well and incubated for $12 \mathrm{H}$ at $37^{\circ} \mathrm{C}$. The cells were then transfected (see section 3.3.3) with $\mathrm{C}$ terminus One-STrEPtag $\operatorname{PrP}^{\mathrm{C}}$ plasmids for variable times $(24 \mathrm{H}, 36 \mathrm{H}$ and $48 \mathrm{H})$. The culture media was then removed and replaced prior to MTS [3-(4, 5-dimthylthiazol-2-yl)-5-(3carboymethoxyphenyl)-2-(4-sulfophenyl)-2Htetrazolium, inner salt] treatment. The effect of $\mathrm{PrP}^{\mathrm{C}}$ presence on cell viability was measured using the MTS cell proliferation assay, which measures the reduction of MTS tetrazolium salt to formazan by metabolically active cells [Cory et al. 1991]. The cells were then treated with a 1:20 ratio of MTS reagent (Promega Co. Madison, WI, USA) $2 \mathrm{mg} / \mathrm{ml}$ with $05 \%$ Glucose and PMS $0.92 \mathrm{mg} / \mathrm{ml}$ with $0.5 \%$ Glucose. Cells were incubated for $1 \mathrm{H}$ at $37^{\circ} \mathrm{C}$ for color development, and the absorbance values were read at $490 \mathrm{~nm}$ using a Multiscan plate reader (Labsystems, Virginia, USA) and Accent software 2.6. Background absorbance from controls was subtracted from sample wells after the final absorbance was obtained.

Trypan blue exclusion was also used to check for cell viability. In subsequent experiments viability was determined by counting the number of cells in 10 fields (20x objective) selected at random on coverslips containing either transfected or untransfected (control) cells.

The Nuclear Area Factor (NAF) for transfected and non-transfected cells was ere determined by fluorescent staining of the nucleus using DAPI, followed by digital microscopy. The measurement of the nuclear area and nuclear circularity was done using Image $\mathrm{J}$ analysis software [Daniel and DeCoster 2004]. 


\subsubsection{Caspase-3 activity assay}

The Caspase-3-activity assay allows quantitative measurement of change in caspase-3 (DEVDase) protease activity, which is an early regulatory event in the apoptotic cell death process. The assay was performed using Caspase- 3 activity assay kits according to the manufacturer's recommendations. Briefly, untreated conrol, empty vector transfected and C-terminus One-STrEP-tag $\mathrm{PrP}^{\mathrm{C}}$ transfected cells were lysed in the cell lysis buffer for $15 \mathrm{~min}$. at $4{ }^{\circ} \mathrm{C}$ followed by centrifugation at $10000 \mathrm{x}$ g. Protein concentration was estimated in the supernatants and the total cell lysate $(50 \mu \mathrm{g})$ was then incubated with $50 \mu \mathrm{M}$ caspase-3 specific substrate DEVD-pNA for $4-5 \mathrm{H}$ at $37^{\circ} \mathrm{C}$. The caspase-3 inhibitor Z-vad-FMK (20 mM) was used as a control. Caspase-3 mediated release of pNA was measured by absorbance at $405 \mathrm{~nm}$. Background absorbance from the control (untreated cells) was subtracted from the the final absorbance obtained for the samples.

\subsubsection{Brefeledin A treatment}

Brefeldin A (BFA), a metabolite of the fungus Eupenicillium brefeldianum, specifically and reversibly blocks protein transport from the endoplasmic reticulum (ER) to the Golgi apparatus in many cell-types and species. The cells were treated with 1 $\mu \mathrm{g} / \mathrm{ml}$ and $10 \mu \mathrm{g} / \mathrm{ml}$ of BFA after $24-48 \mathrm{H}$ of transient transfection at different time points in HpL3-4 cells and same treatment was applied to the SH-SY5Y stable $\mathrm{PrP}^{\mathrm{C}}$ cells. After BFA treatment the cells were lysed (see section 3.3.7) for expression analysis and immunomounted (see section 3.3.6) for localization analysis.

\subsubsection{Microtubule disruption treatment}

The microtubules were disrupted as preiously described [Vonderheit and Helenius2005]. Briefly, cells were cultivated (see section 3.3.2) and treated with $5 \mu \mathrm{M}$ nocodazole for $30 \mathrm{~min}$., $3 \mathrm{H}$, and $24 \mathrm{H}$ at $37^{\circ} \mathrm{C}$ after transient (section 3.3.3) transfection in HpL3-4 cells and SH-SY5Y stable $\mathrm{PrP}^{\mathrm{C}}$ cells. After nocodazole treatment the cells were lysed (see section 3.3.7) for expression analysis or immunomounted (see section 3.3.6) for localization analysis.

\subsubsection{Protease K degradation assay}

The total cell lysates (siRNA treated and non-treated) were incubated for $60 \mathrm{~min}$. with shaking at $37^{\circ} \mathrm{C}$ in the presence of PK $(50 \mu \mathrm{g} / \mathrm{ml})$. The digestion was stopped by 
adding electrophoresis sample buffer and the protease-resistant PrP was examined by western blotting.

\subsection{Statistical analysis}

All results in this study were obtained from at least four independent sets of experiments and were expressed as mean \pm S.D using descriptive statistics. Densitometric analysis of 1-DE gels were performed using ImageJ 1.43u software.

\subsection{Safety measures}

All operations with genetically modified organisms and plasmid DNA were performed in accordance with the Gentechnikgesetz of 1990 and the rules described by the Gentechnik-Sicherheitsverordnung of 1990. Ethidium bromide, formaldehyde, acrylamide and other chemicals deleterious for the environment, when used in the course of the work, were carefully managed and disposed of properly in accordance with institutional guidelines. All waste was disposed of according to institutional instructions. 


\section{Results}

Proteins interact with each other to perform their biological functions. Therefore, it is crucial to identify the different partners with which $\operatorname{PrP}^{\mathrm{C}}$ might be associated in the cell in order to uncover its physiological role. In recent years, many groups have tried to identify the proteins which functionally interact with $\operatorname{PrP}^{\mathrm{C}}$. However, the complex trafficking and internalization pattern of $\mathrm{PrP}^{\mathrm{C}}$ restricts ligand purification.

In this study, a neuronal cell model expressing C-terminus One-STrEP-tag PrP was established to identify the interacting proteins of $\operatorname{PrP}^{\mathrm{C}}$. The novel interacting proteins of $\mathrm{PrP}^{\mathrm{C}}$ identified, with suggested roles in trafficking and internalization, were further characterized using different molecular biological techniques.

\subsection{Generation and expression of C-terminus One-STrEP-tag- $\operatorname{PrP}^{\mathrm{C}}$}

Mammalian expression vector encoding C-terminus One-STrEP-tag $\operatorname{PrP}^{\mathrm{C}}$ was established with combinatorial cloning. The PRNP gene was first equipped with essential recombination sequences for the transfer of PRNP from pENTRY-IBA (donor vector) to the acceptor vector. The generated acceptor vector ( $p E S G-103-P R N P)$ was checked by restriction digestion analysis, which showed the $830 \mathrm{bp}$ fragment of PRNPC-Terminus One-STrEP-tag (Figure 4).

To test the C-terminus One-STrEP-tag system, HpL3-4 cells lacking endogenous $\mathrm{PrP}^{\mathrm{C}}$ were transiently transfected with the vector containing C-terminus One-STrEP-tag $\operatorname{PrP}^{\mathrm{C}}\left(\mathrm{PrP}^{+/+}\right.$or $\left.\mathrm{PrP}^{\mathrm{C}}\right)$ or control vector without the $\mathrm{PrP}^{\mathrm{C}}$ construct $\left(\operatorname{PrP}^{-/}\right)$. Immunoblotting with $\mathrm{PrP}^{\mathrm{C}}$ and One-STrEP-tag antibody confirmed its expression in transfected cells (Figure $5 \mathrm{~A}-\mathrm{C}$ ). The $\operatorname{PrP}^{\mathrm{C}}$ expression/localization was further confirmed using anti-One-STrEP-tag antibody which showed complete overlapping with $\operatorname{PrP}^{\mathrm{C}}$ (Figure 6). 
A.

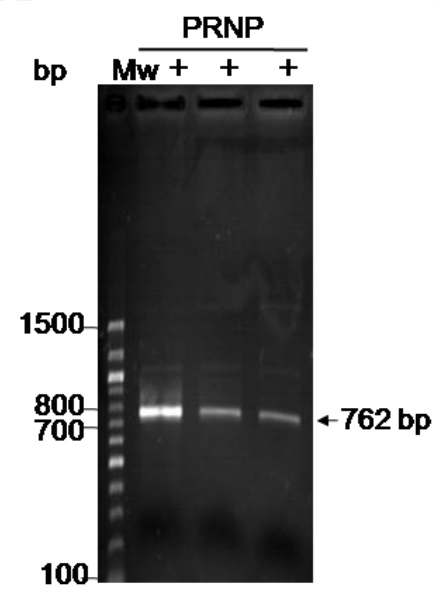

B.

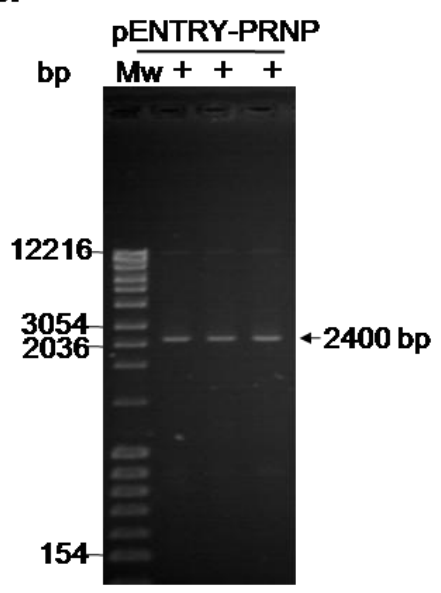

C.

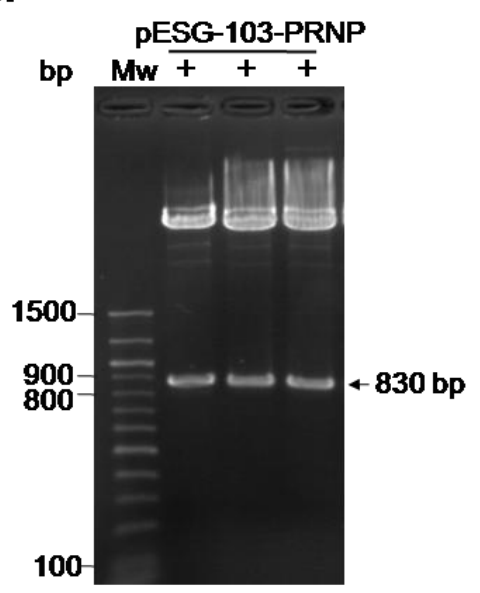

D.

\begin{tabular}{|c|c|c|}
\hline & $\mathbf{N}$-terminus & C-terminus \\
\hline
\end{tabular}

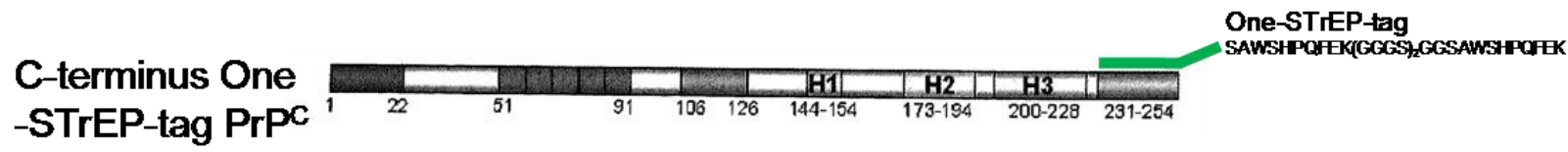

Figure 4 C-terminus One-STrEP-tag PrP ${ }^{C}$ plasmid: (A) Amplification of the PRNP gene (molecular weight $762 \mathrm{bp}$ ) through genomic DNA extracted from whole human blood. (B) Donor vector (pENTRY-PRNP, molecular weight 2400 bp) generated with combinatorial cloning. (C) Restriction digestion of pESG-103-PRNP with Xbal and Hind III enzymes showed an 830 bp PRNP-C-terminus OneSTrEP-tag fragment (D) Schematic representation of $\operatorname{PrP}^{\mathrm{C}}$ attached with One-STrEP-tag at its Cterminus. 
A.

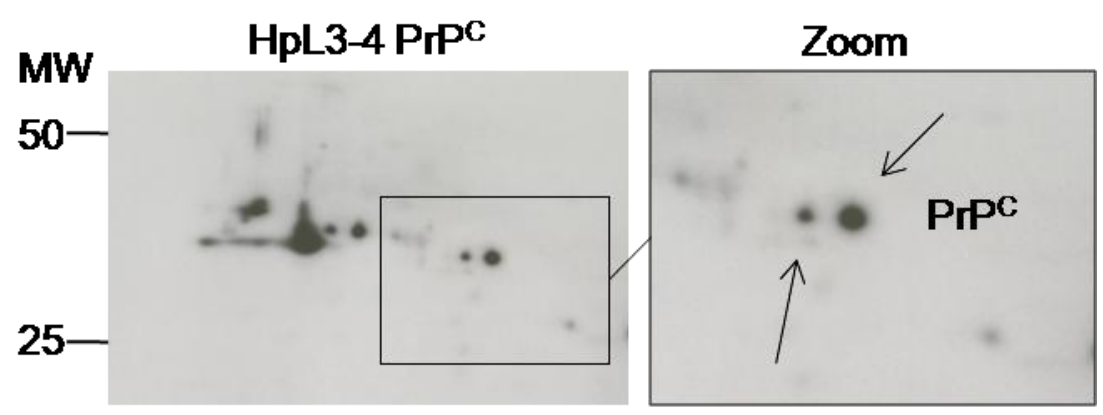

HpL3-4 PrP ${ }^{-1}$
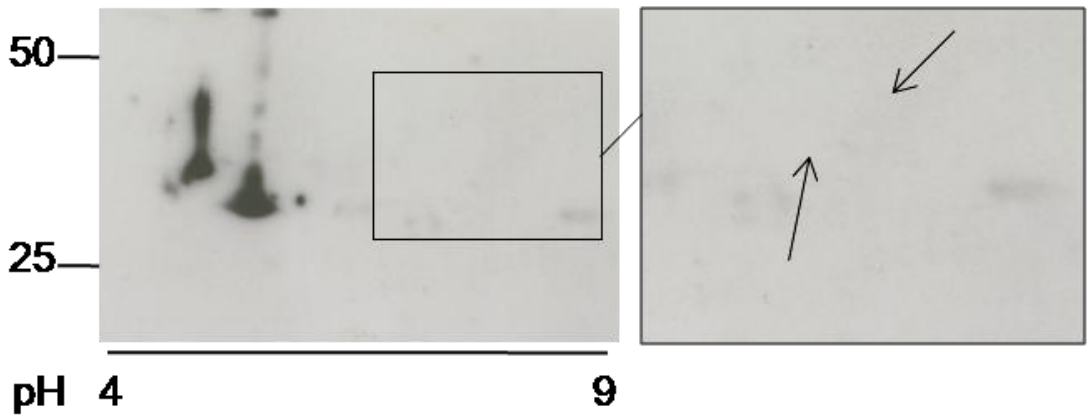

9

B.

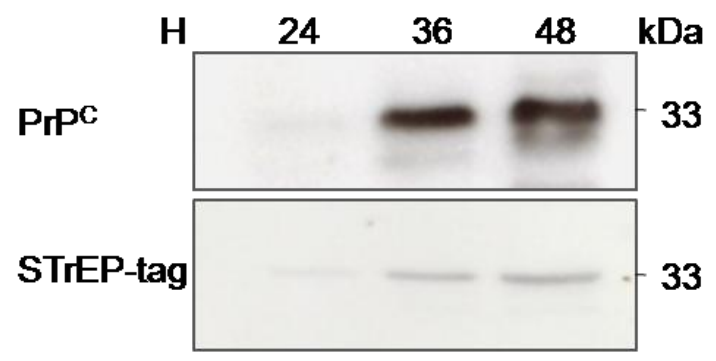

C.

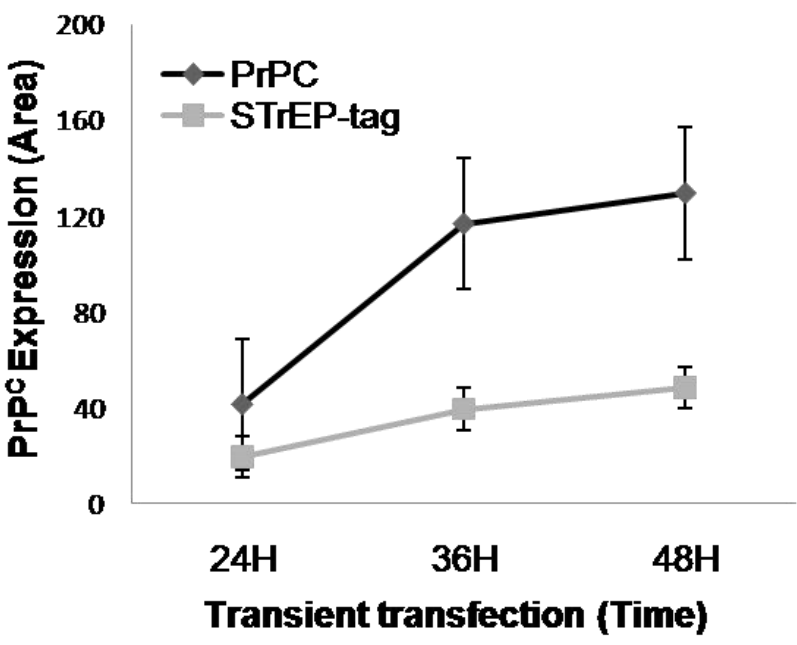

Figure $5 \mathrm{PrP}^{\mathrm{C}}$ expression in HpL3-4 cells after transient transfection: (A) C-terminus One-STrEP tagged $\operatorname{PrP}^{\mathrm{C}}$ (HpL3-4 $\mathrm{PrP}^{\mathrm{C}}$ ) and control vector without $\mathrm{PrP}^{\mathrm{C}}$ construct (HpL3-4 PrP ${ }^{-1}$ ), transiently expressed for $48 \mathrm{H}$ in HpL3-4 cell line. Linear 7cm IPG strips (pH 3-10) were used and loaded with $80 \mu \mathrm{g}$ of total cell lysate and were analyzed by 2-DE immunoblotting using $6 \mathrm{H} 4 \mathrm{PrP}^{\mathrm{C}}$ specific antibody (B) $\operatorname{PrP}^{C}$ expression after 24,36 and $48 \mathrm{H}$ of C-terminus One-STrEP-tag $\operatorname{PrP}^{C}$ transient transfection (B) Densitometric analysis of time dependent $\mathrm{PrP}^{\mathrm{C}}$ expression after transient transfection. $\mathrm{n}=4$. 
PrP'-

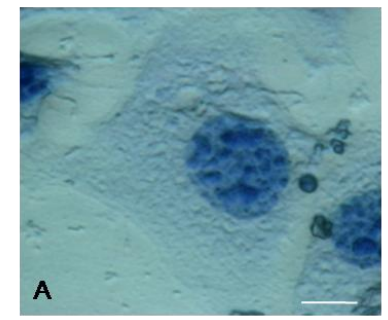

PrPc
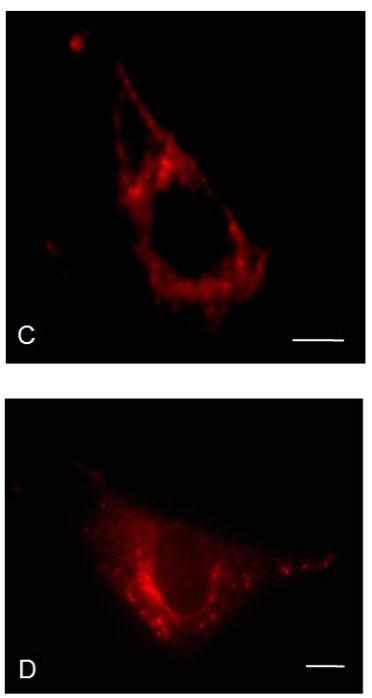

PrPc

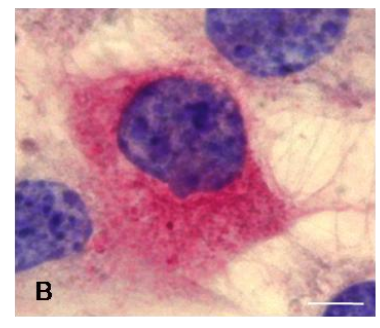

One-STrEP-tag
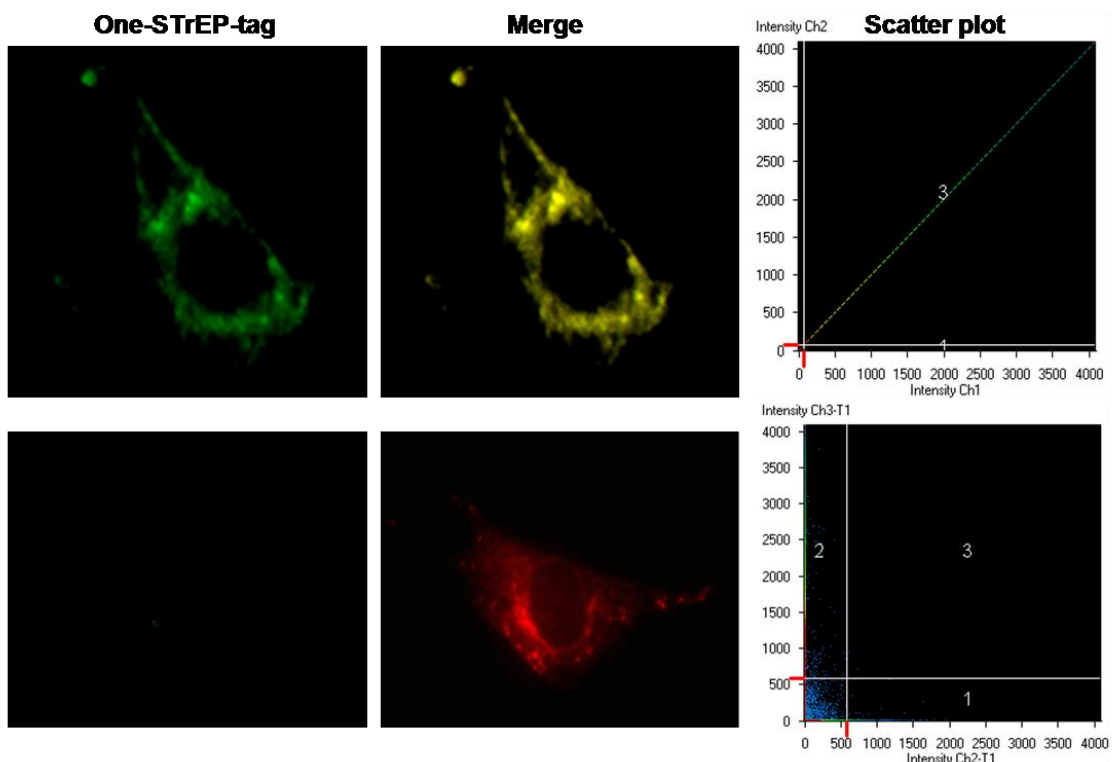

Figure 6 PrP ${ }^{\mathrm{C}}$ localization in HpL3-4 cells after transient transfection: C-terminus One-STrEP tagged $\mathrm{PrP}^{C}$ and control $\mathrm{PrP}^{C}$ transiently expressed for $48 \mathrm{H}$ in HpL3-4 cell line. Cells were fixed, made permeable with Triton-X-100. (A and B) Immunohistochemistry of $\operatorname{Pr}^{C}$ expression labeled with $6 \mathrm{H} 4$ anti- $\operatorname{PrP}^{\mathrm{C}}$ antibody. Immunofluorescent staining of One-STrEP tagged $\operatorname{PrP}^{\mathrm{C}}(\mathrm{C})$ and control $\operatorname{PrP}^{\mathrm{C}}$ (D) with $6 \mathrm{H} 4$ anti- $\mathrm{PrP}^{\mathrm{C}}$ antibody and STrEP mAb classic anti- One-STrEP tag antibody followed detection by Cy3 (red)- and Alexa488 (green)- conjugated secondary antibodies. (Scale bar: $10 \mu \mathrm{m}$ ). Typical scatter plot of the individual pixels from paired images. The region 3 demonstrated the overlapping region, regions 2 and 1 corresponding to green and red pixels, respectively, with no color mixing. Overlapping was quantified with the LSM 5103 software (Carl Zeiss, Germany).

\section{2 $\operatorname{PrP}^{\mathrm{C}}$ expression and cell viability}

\subsection{1 $\mathrm{PrP}^{\mathrm{C}}$ expression and cell viability in HpL3-4 and SH-SY5Y cells}

To check the influence of $\operatorname{PrP}^{C}$ expression on cell viability, C-terminus OneSTrEP-tagged $\operatorname{PrP}^{\mathrm{C}}$ was transiently transfected for 24,36 and $48 \mathrm{H}$ in HpL3-4 cells (Figure 5). The mitochondrial respiratory activity of non-apoptotic cells was determined 
by MTS assay. Cell viability of $\mathrm{HpL} 3-4 \mathrm{PrP}^{\mathrm{C}}$ was not significantly different as compared to $\mathrm{PrP}^{-/}$after $24 \mathrm{H}$ and $36 \mathrm{H}$ of transient transfection. However, the cell viability was slightly but significantly increased after $48 \mathrm{H}$ of transient expression (Figure 7). On the other hand, the stably expressing $\mathrm{PrP}^{\mathrm{C}} \mathrm{SH}-\mathrm{SY} 5 \mathrm{Y}$ cells showed significant decreased viability as compared to control pCIneo cells (Figure 8).

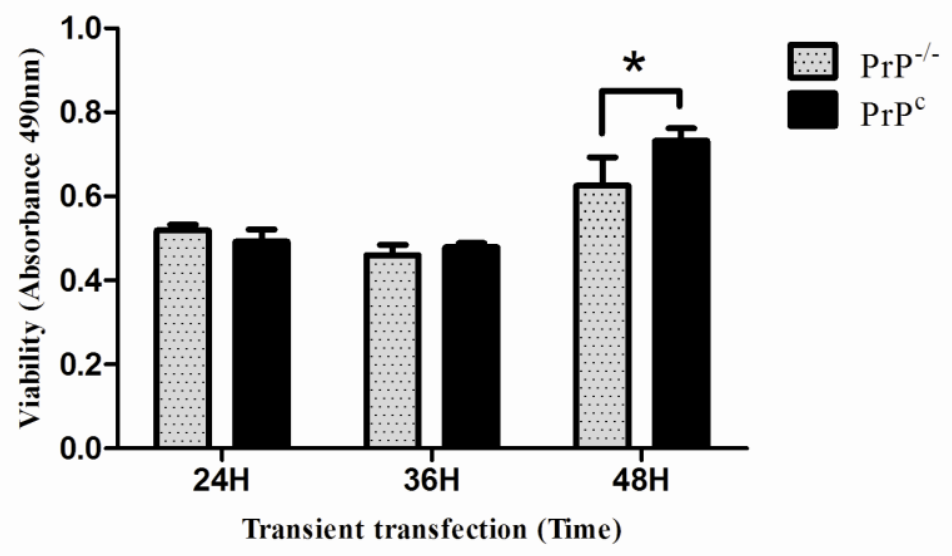

Figure 7 Viability of transient $\operatorname{PrP}^{\mathrm{C}}$ expressing HpL3-4 cells: Cells were transiently transfected with $\mathrm{PrP}^{-/}$and $\mathrm{PrP}^{\mathrm{C}}$ and cell viability was measured by MTS assay after 24,36 and $48 \mathrm{H}$ of expression. The viability values are shown as absorbance at $490 \mathrm{~nm}$. Data points are the means $\pm \mathrm{SEM}$ of values from four different experiments. The significance was performed by student's $t$-test $\left({ }^{*} P<0.05\right)$.

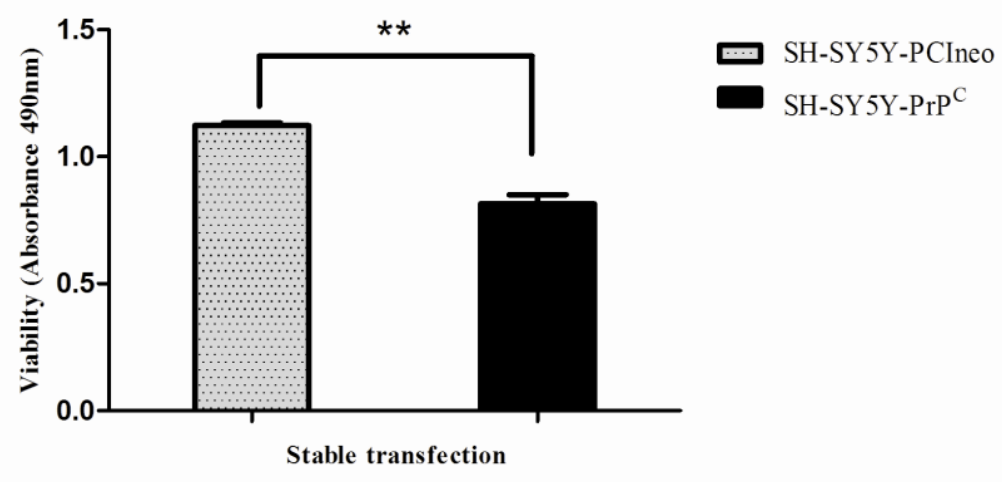

Figure 8 Viability of stable PrP ${ }^{C}$ expressing SH-SY5Y cells: SH-SY5Y cells stably expressing $\mathrm{pClneo}$ (control) and $\operatorname{PrP}^{\mathrm{C}}\left(0.5 \times 10^{6}\right.$ cells/ml) and the viability of the cells were measured by MTS assay at $490 \mathrm{~nm}$ by spectrophotometry. The viability values are shown as absorbance at $490 \mathrm{~nm}$. 
Data points are the means \pm SEM of values from four different experiments. The significance was performed by student's t-test $\left({ }^{* *} \mathrm{P}<0.01\right)$.

\subsubsection{Caspase-3 activity in $\operatorname{PrP}^{\mathrm{C}}$ expressing cells}

To test the cytotoxic nature of $\mathrm{PrP}^{\mathrm{C}}$, an apoptotic marker enzyme caspase-3 activity was measured in transient and stable $\mathrm{PrP}^{\mathrm{C}}$ expressing cells. Caspase- 3 activity was analyzed in cell lysates incubated with pNA-conjugated caspase-3 specific substrate DEVD. Free cleaved pNA was detected by fluorescence measurement. Relative Caspase-3 activity was analyzed in SH-SY5Y cells stably expressing pCineo (control) and $\mathrm{PrP}^{\mathrm{C}}$ and also in transient expressing $\mathrm{PrP}^{\mathrm{C}} \mathrm{HpL}$-4 4 cells. The Caspase-3 activity was significantly increased in pCineo control and in $\mathrm{HpL3}-4 \mathrm{PrP}^{-/}$cells after staurosporine treatment. The cells expressing transient and stable $\mathrm{PrP}^{\mathrm{C}}$ showed no significant (ns) regulation of caspase-3 enzyme activity and demonstrated the antiapoptotic nature of $\mathrm{PrP}^{\mathrm{C}}$ after staurosporine treatment (Figure 9). 

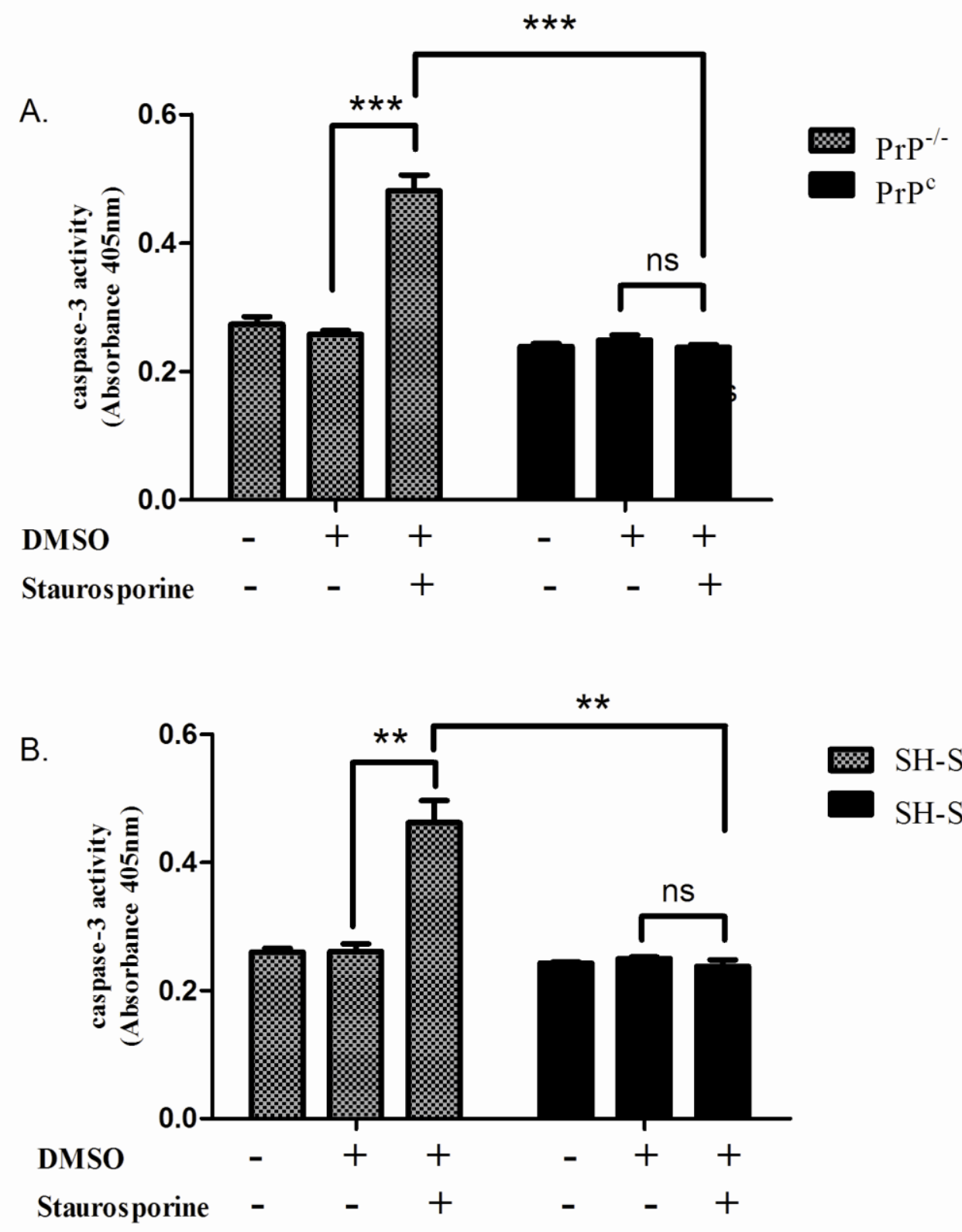

Figure 9 Caspase-3 activity in HpL3-4 and SH-SY5Y cells: Total cell lysates were isolated from HpL3-4 cells (transiently expressing $\mathrm{PrP}^{\mathrm{C}}$ ) and $\mathrm{SH}-\mathrm{SY} 5 \mathrm{Y}$ cells (expressing stable PCIneo (empty vector) and $\mathrm{PrP}^{\mathrm{C}}$ ). Caspase-3 activity was detected by fluorescence measurement of the cleaved pNA from the substrate peptide DEVD-pNA. Densitometric analysis (A) HpL3-4 cells (B) SH-SY5Y cells. Data points are the means $\pm S D$ of values from four different experiments. The significance was tested by student's t-test $\left.{ }^{* *} \mathrm{P}<0.01,{ }^{* * *} \mathrm{P}<0.001\right)$ and $n s=$ non significant. 


\subsection{Purification and identification of $\operatorname{PrP}^{\mathrm{C}}$ interacting proteins}

C-terminus One-STrEP-tag affinity chromatography and reverse coimmunoprecipitation methods were employed in this study to purify the interacting proteins under physiological conditions.

\subsubsection{C-terminus One-STrEP-tag $\operatorname{PrP}^{\mathrm{C}}$ affinity purification of $\mathrm{PrP}^{\mathrm{C}}$ complex}

HpL3-4 cells lacking endogenous $\mathrm{PrP}^{\mathrm{C}}$ were transiently transfected with the vector containing C-terminus One-STrEP-tag $\mathrm{PrP}^{\mathrm{C}}\left(\mathrm{PrP}^{+/+}\right)$or control vector without $\operatorname{PrP}^{C}$ construct $\left(\operatorname{PrP}^{--}\right)$. The efficiency of C-terminus One-STrEP-tag $\operatorname{PrP}^{C}$ protein recovery through the STrEP-Tactin column was optimized by using buffers designed to not disrupt physiological binding of the protein during its elution and purification. The total cell lysate $(T C L)$ was prepared and then incubated $(4 \mathrm{mg})$ with pre-equilibrated STrEP-Tactin superflow beads to purify $\operatorname{PrP}^{C}$ along with its interacting proteins from the total cell lysates. The eluates from STrEP-Tactin superflow beads were precipitated with methanol/chloroform and then resuspended in Laemmli buffer, 1-DE separated, electrotransferred to a PVDF membrane and detected with $6 \mathrm{H} 4 \mathrm{PrP}^{\mathrm{C}}$ as well as One-STrEPtag antibodies (Figure $10 \mathrm{~A}$ and $\mathrm{B}$ ). Following $6 \mathrm{H} 4 \mathrm{PrP}^{\mathrm{C}}$ and One-STrEP-tag specific western blots, the remaining eluate was 1-DE separated and silver nitrate stained (Figure 10C). Whole lanes from $\mathrm{PrP}^{+/+}$and $\mathrm{PrP}^{-/}$transfected eluates were excised, ingel digested and proteins were identified by Q-TOF MS/MS analysis. All the proteins identified in the $\mathrm{PrP}^{-/}$lane bands were considered background contaminants and subtracted from the list of proteins identified from $\mathrm{PrP}^{+/+}$transfected eluates. Both known and novel $\mathrm{PrP}^{\mathrm{C}}$ interacting partners were among the proteins identified in this study (Table 8). 


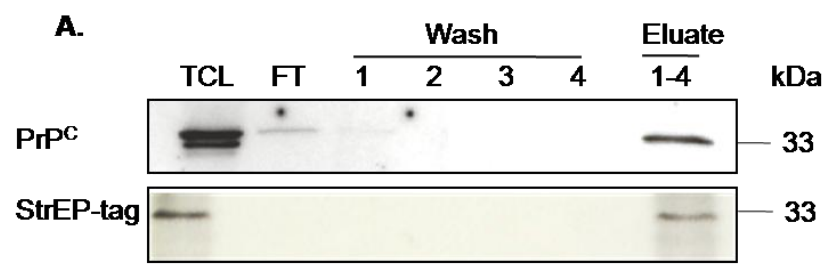

c.

B.
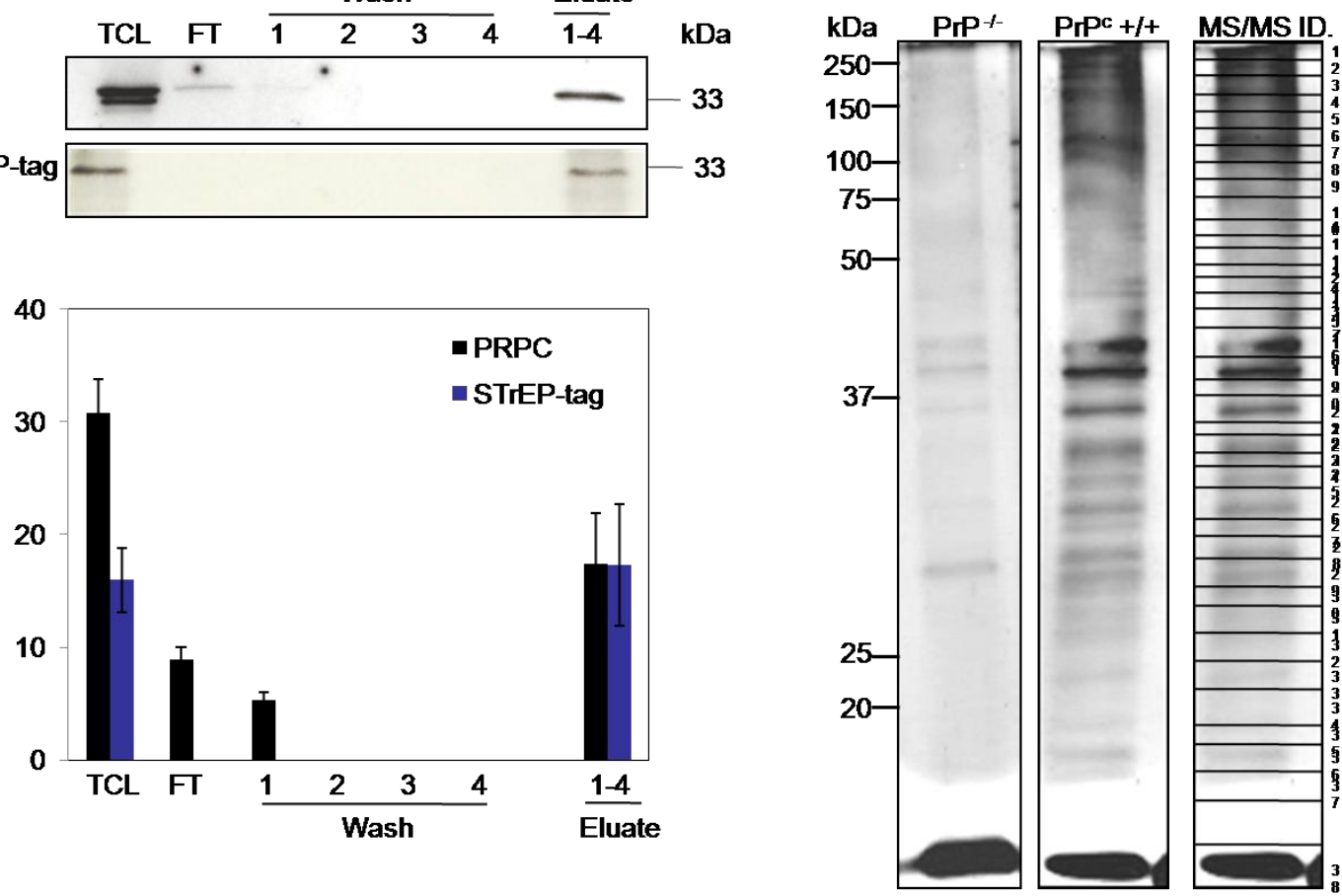

D. $\frac{\mathrm{PrP}^{\mathrm{C}}}{\mathrm{TCL} \text { Elute }} \frac{\mathrm{PrP}^{--}}{\mathrm{TCL} \text { Eluate }}$

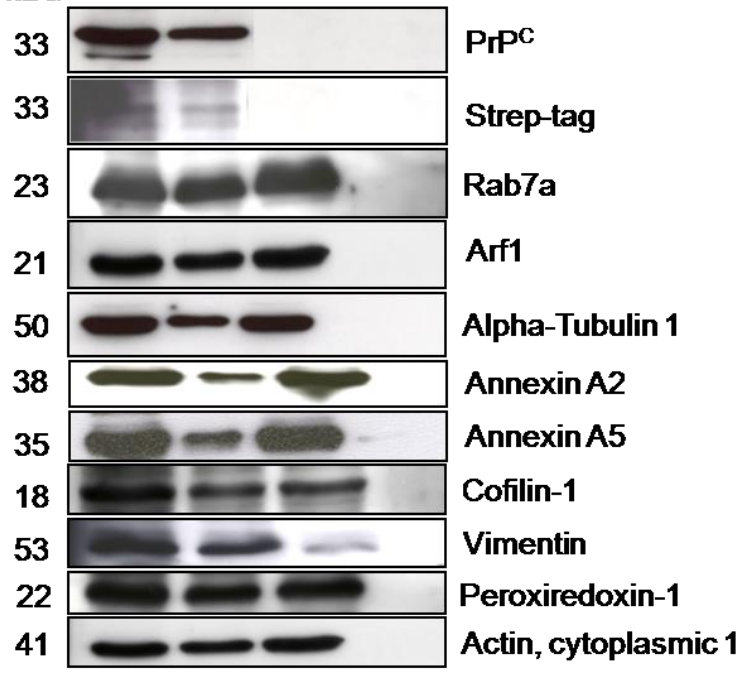

Figure 10 Identification of $\mathrm{PrP}^{\mathrm{C}}$ multiprotein complex from HpL3-4 cells purification by C-terminus One-STrEP-tag: TCL after $48 \mathrm{H}$ of transient transfection was prepared and subjected to the C-terminus One-STrEP-tag purification method. Aliquots from each step of the purification (starting material (TCL) $5 \%$; flow-through (FT) $50 \%$; washes $50 \%$; eluates 25\%) were analyzed by immuno blotting using (A) $6 \mathrm{H} 4$ and One-STrEP-tag specific antibodies (B) Densitometric analysis from immuno blotts $n=4( \pm S D)$. (C) Silver-stain 1-DE, proteins identified by MS/MS analysis are listed in Table 8 (D) Confirmatory immuno blotting using 3F4, One-STrEP-tag, and other interacting proteins specific antibodies.

Fifteen out of the forty-three identified proteins have already been described as interacting partners of $\mathrm{PrP}^{\mathrm{C}}$ in previous studies (Table 8). Three of them (tubulin alpha$1 \mathrm{~A}$, tubulin beta-5 chain, elongation factor 1-alpha-1), are also known for their interaction with $\mathrm{PrP}^{\mathrm{SC}}$. However, five other proteins (actin, cofilin-1, Glyceraldehyde 3- 
phosphate dehydrogenase (GAPDH), D-3-phosphoglycerate dehydrogenase and heat shock protein 90-alpha) from our identified proteins were identified in these experiments as interacting partners for $\operatorname{PrP}^{\mathrm{Sc}}$ but not for $\operatorname{PrP}^{\mathrm{C}}$. Collectively, $23 \%$ of the interacting partners of $\mathrm{PrP}^{\mathrm{C}}$ identified in this study are associated with cytoskeleton-cell growth/maintenance, $23 \%$ cell communication and signal transduction, $14 \%$ metabolism: energy pathways, $14 \%$ protein metabolism, $14 \%$ oxioreductase: stress response and $5 \%$ protein folding proteins. The remaining $7 \%$ proteins fall into other three functional groups (Figure 11). A selection of identified proteins was further validated by immunoblotting using the protein specific antibodies from purified OneSTrEP-tag eluate. PrP ${ }^{C}$ and Strep-tag signal was detected in TCL and One-STrEP-tag elute from $\mathrm{PrP}^{+/+}$or $\mathrm{PrP}^{\mathrm{C}}$. Rab7a, Arf1, alpha tubulin 1, annexin $\mathrm{A} 2$, annexin $\mathrm{A}$, actin cytoplasmic 1, cofilin-1, vimentin, and peroxiredoxin-1 was only detected in $\operatorname{PrP}^{\mathrm{C}}$ OneSTrEP-tag elute. No signal was detected in the control purified elutes (Figure 10D), confirming the specificity of the purification process. 
Table 8 PrP $^{C}$ interacting proteins: Interacting proteins were identified after C-terminus OneSTrEP-tag purification and Q-TOF MS/MS analysis. The biological functions are assigned according to the ExPASy protein database (http://expasy.org/) and the Human Protein Reference Database [Keshava Prasad et al. 2009]. B. No = Band No. listed in Figure 4C, Acc. No.= Swissprot Accession No., PrP ligand $=$ previously identified as a $\operatorname{PrP}^{C}$ interacting partner, $\operatorname{PrP}^{\mathrm{Sc}_{\mathrm{c}}}$ ligand= previously identified as a $\operatorname{PrP}^{\mathrm{Sc}}$ interacting partner. The detailed list of list of interacting proteins with score, peptide match, sequence coverage and sequences can be found in appendix $B$.

\begin{tabular}{|c|c|c|c|c|c|c|}
\hline $\begin{array}{l}\text { B. } \\
\text { No }\end{array}$ & $\begin{array}{l}\text { Acc. } \\
\text { No. }\end{array}$ & Protein Description & $\begin{array}{l}\text { PrP } \\
\text { Ligand }\end{array}$ & $\begin{array}{l}\text { PrP } \\
\text { Ligand }\end{array}$ & $\begin{array}{l}\text { Mass } \\
(k D a)\end{array}$ & Function (ExPASy)/ References \\
\hline \multicolumn{7}{|c|}{ Cytoskeleton: Cell growth /maintenance } \\
\hline 14 & $\mathrm{P} 60710$ & Actin, cytoplasmic 1 & Novel & $\begin{array}{l}\text { Known } \\
\text { [Morel et } \\
\text { al. 2008] }\end{array}$ & 41.7 & Highly conserved, involved in cell motility \\
\hline 21 & P07356 & Annexin A2 & $\begin{array}{l}\text { Known } \\
\text { [Morel e } \\
\text { al. 2008] }\end{array}$ & - & 38.6 & $\begin{array}{l}\text { Calcium-regulated membrane-binding } \\
\text { protein }\end{array}$ \\
\hline 14 & Q8BFZ3 & Beta-actin-like protein 2 & Novel & - & 41.9 & Cell motility \\
\hline 35 & P18760 & Cofilin-1 & Novel & $\begin{array}{l}\text { Known } \\
\text { [Giorgi et } \\
\text { al. 2009] }\end{array}$ & 18.5 & $\begin{array}{l}\text { Controls reversible actin polymerization, } \\
\text { depolymerization and is major component } \\
\text { of intranuclear and cytoplasmic actin rods }\end{array}$ \\
\hline 9 & P26041 & Moesin & Novel & - & 67.7 & $\begin{array}{l}\text { Probably involved in connection of major } \\
\text { cytoskeletal structures to the plasma } \\
\text { membrane }\end{array}$ \\
\hline 3 & Q8VDD5 & Myosin-9 & Novel & - & 226.2 & $\begin{array}{l}\text { Cytokinesis, cell shape, secretion and } \\
\text { capping }\end{array}$ \\
\hline 33 & Q9WVA4 & Transgelin-2 & Novel & - & 22.3 & Muscle organ development \\
\hline 12 & P68369 & Tubulin alpha- $1 \mathrm{~A}$ & Known & $\begin{array}{l}\text { Known } \\
\text { [Nieznans } \\
\mathrm{ki} \text { et al } \\
2005]\end{array}$ & $\begin{array}{l}50.1 \\
s \\
1 .\end{array}$ & Major constituent of microtubules \\
\hline 13 & P99024 & Tubulin beta- 5 chain & Known & Known & 49.6 & Major constituent of microtubules \\
\hline 12 & P20152 & Vimentin & Novel & - & 53.6 & $\begin{array}{l}\text { Class-III intermediate filaments, found in } \\
\text { various non-epithelial cells }\end{array}$ \\
\hline
\end{tabular}

Cell communication : Signal transduction

\begin{tabular}{|c|c|c|c|c|c|c|}
\hline 27 & P62259 & 14-3-3 protein epsilon & $\begin{array}{l}\text { Known } \\
\text { [Satoh et } \\
\text { al. 2005] }\end{array}$ & - & 29.1 & Adapter protein in signaling pathway \\
\hline 27 & P63101 & 14-3-3 protein zeta/delta & Known & - & 27.7 & Adapter protein in signaling pathway \\
\hline 24 & P14206 & Laminin receptor 1 & $\begin{array}{l}\text { Known } \\
\text { [Gauczyn } \\
\text { ski et al. } \\
\text { 2001] }\end{array}$ & - & 32.8 & $\begin{array}{l}\text { Receptor for laminin, cell adhesion, cell } \\
\text { fate determination and tissue } \\
\text { morphogenesis, acts as a receptor for } \\
\text { pathogenic prion protein, viruses, and } \\
\text { bacteria }\end{array}$ \\
\hline
\end{tabular}




\begin{tabular}{|c|c|c|c|c|c|}
\hline P63038 & $60 \mathrm{kDa}$ heat shock protein & $\begin{array}{l}\text { Known } \\
\text { [Edenhof } \\
\text { er et al. } \\
1996 \text { ] }\end{array}$ & - & 60.9 & $\begin{array}{l}\text { Facilitates the correct folding of imported } \\
\text { proteins, prevents misfolding and } \\
\text { promotes the refolding under stress } \\
\text { conditions in the mitochondrial matrix }\end{array}$ \\
\hline P84078 & ADP-ribosylation factor 1 & Novel & - & 20.6 & $\begin{array}{l}\text { Involved in protein trafficking among } \\
\text { different compartments }\end{array}$ \\
\hline P10107 & Annexin A1 & Novel & - & 38.7 & $\begin{array}{l}\text { Calcium/phospholipid-binding protein, } \\
\text { promotes membrane fusion and is } \\
\text { involved in exocytosis This protein } \\
\text { regulates phospholipase A2 activity }\end{array}$ \\
\hline P48036 & Annexin A5 & Novel & - & 35.9 & $\begin{array}{l}\text { Anticoagulant protein, indirect inhibitor of } \\
\text { the thromboplastin-specific complex, } \\
\text { which is involved in the blood coagulation } \\
\text { cascade }\end{array}$ \\
\hline Q60864 & Stress-induced-phosphoprotein 1 & $\begin{array}{l}\text { Known } \\
\text { [Zanata } \\
\text { et al. } \\
\text { 2002] }\end{array}$ & - & 62.5 & $\begin{array}{l}\text { Mediates the association of the molecular } \\
\text { chaperones HSC70 and HSP90 }\end{array}$ \\
\hline P51150 & Ras-related protein Rab-7a & Novel & - & 23.4 & Involved in late endocytic transport \\
\hline Q8N3E9 & $\begin{array}{l}\text { Phosphatidylinositol-4,5- } \\
\text { bisphosphate phosphodiesterase } \\
\text { delta-3 (PLC) }\end{array}$ & Novel & - & 89.2 & $\begin{array}{l}\text { Hydrolyzes phosphatidylinositol } 4,5- \\
\text { bisphosphate (PIP2) to generate } 2 \text { second } \\
\text { messenger molecules diacylglycerol } \\
\text { (DAG) and inositol 1,4,5-trisphosphate } \\
\text { (IP3). DAG mediates the activation of } \\
\text { protein kinase C (PKC), while IP3 releases } \\
\mathrm{Ca}^{2+} \text { from intracellular stores. May } \\
\text { participate in cytokinesis by hydrolyzing } \\
\text { PIP2 at the cleavage furrow. }\end{array}$ \\
\hline
\end{tabular}

Metabolism: Energy pathways

\begin{tabular}{|c|c|c|c|c|c|c|}
\hline 16 & P17182 & Alpha-enolase & Novel & - & 47.1 & $\begin{array}{l}\text { Multifunctional enzyme, role in glycolysis, } \\
\text { growth control, hypoxia tolerance, allergic } \\
\text { responses, serves as a receptor and } \\
\text { activator of plasminogen on the cell } \\
\text { surface of leukocytes and neurons, } \\
\text { stimulates immunoglobulin production }\end{array}$ \\
\hline 16 & P05202 & $\begin{array}{l}\text { Aspartate aminotransferase, } \\
\text { mitochondrial }\end{array}$ & Novel & - & 47.3 & $\begin{array}{l}\text { Amino acid metabolism, facilitates cellular } \\
\text { uptake of long-chain free fatty acids }\end{array}$ \\
\hline 17 & P05064 & Fructose-bisphosphate aldolase A & Novel & - & 39.3 & Glycolysis \\
\hline 18 & P16858 & GAPDH & Novel & $\begin{array}{l}\text { Known } \\
\text { [Giorgi e } \\
\text { al. 2009] }\end{array}$ & 35.7 & Glycolysis \\
\hline 26 & 009131 & Glutathione S-transferase omega-1 & Novel & - & 27.4 & $\begin{array}{l}\text { Exhibits glutathione-dependent thio } \\
\text { transferase and dehydroascorbate } \\
\text { reductase activities }\end{array}$ \\
\hline
\end{tabular}



peroxides generated during metabolism, participates in the signaling cascades of growth factors and tumor necrosis factoralpha, and regulates GDPD5 function

\begin{tabular}{|c|c|c|c|c|c|c|}
\hline \multicolumn{7}{|c|}{ Protein metabolism } \\
\hline 6 & P58252 & Elongation factor 2 & Novel & - & 95.2 & $\begin{array}{l}\text { GTP-dependent translocation of the } \\
\text { nascent protein chain from the A-site to } \\
\text { the P-site of the ribosome }\end{array}$ \\
\hline 10 & P63017 & Heat shock cognate $71 \mathrm{kDa}$ protein & Novel & - & 70.8 & Chaperone \\
\hline 12 & P09103 & Protein disulfide-isomerase & Novel & - & 57.1 & $\begin{array}{l}\text { Catalyzes the formation, breakage and } \\
\text { rearrangement of disulfide bonds }\end{array}$ \\
\hline 12 & P27773 & Protein disulfide-isomerase A3 & Novel & - & 56.6 & $\begin{array}{l}\text { Catalyzes the rearrangement of -S-S- } \\
\text { bonds in proteins }\end{array}$ \\
\hline 16 & P19324 & $\begin{array}{l}\text { Serpin } \mathrm{H} 1 \text { ( } 47 \mathrm{kDa} \text { heat shock } \\
\text { protein) }\end{array}$ & Novel & - & 46.5 & $\begin{array}{l}\text { Binds specifically to collagen, involved as } \\
\text { a chaperone in the biosynthetic pathway of } \\
\text { collagen }\end{array}$ \\
\hline 10 & P38647 & Stress-70 protein, mitochondrial & Novel & - & 73.4 & $\begin{array}{l}\text { Implicated in the control of cell proliferation } \\
\text { and cellular aging, also act as a } \\
\text { chaperone }\end{array}$ \\
\hline
\end{tabular}

\begin{tabular}{|c|c|c|c|c|c|}
\hline \multicolumn{6}{|c|}{ Regulation of nucleic acid metabolism } \\
\hline 18 & Q9EQU5 & Protein SET & Novel & 33.3 & $\begin{array}{l}\text { Involved in apoptosis, transcription, } \\
\text { nucleosome assembly and histone binding }\end{array}$ \\
\hline \multicolumn{6}{|c|}{ Protein folding } \\
\hline 33 & Q99LP6 & $\begin{array}{l}\text { GrpE protein homolog } 1 \text {, } \\
\text { mitochondrial }\end{array}$ & Novel & 24.4 & $\begin{array}{l}\text { Essential component of the PAM complex, } \\
\text { control the nucleotide-dependent binding } \\
\text { of mitochondrial HSP70 to substrate } \\
\text { proteins }\end{array}$ \\
\hline 36 & P17742 & $\begin{array}{l}\text { Peptidyl-prolyl cis-trans isomerase } \\
\text { A }\end{array}$ & Novel & 17.9 & $\begin{array}{l}\text { Accelerates the folding of proteins, } \\
\text { catalyzes the cis-trans isomerization of } \\
\text { proline imidic peptide bonds in } \\
\text { oligopeptides }\end{array}$ \\
\hline
\end{tabular}

Cell cycle

\begin{tabular}{llll}
\hline P10126 Elongation factor 1-alpha 1 & Novel & Novel 50 & Promotes the GTP-dependent binding of \\
& & aminoacyl-tRNA to the A-site of ribosomes \\
& during protein biosynthesis
\end{tabular}

\section{Lipopolysaccharide binding; ATP binding}

\begin{tabular}{|c|c|c|c|c|}
\hline 10 P20029 & $\begin{array}{l}78 \mathrm{kDa} \text { glucose-regulated protein } \\
\text { (Bip) }\end{array}$ & $\begin{array}{l}\text { Known } \\
\text { [Jin et } \\
\text { al. 2000] }\end{array}$ & 72.3 & $\begin{array}{l}\text { Role in facilitating the assembly of } \\
\text { multimeric protein complexes inside the } \\
\text { ER }\end{array}$ \\
\hline
\end{tabular}

\section{Oxidoreductase, Stress response}

13 Q61753 D-3-phosphoglycerate Novel Known 56.5 Amino-acid biosynthesis, serine


al. 2000]

9 P07901 Heat shock protein HSP 90-alpha Novel

Known 84.7 Molecular chaperone with ATPase activity [Jin et

al. 2000]

9 P11499 Heat shock protein HSP 90-beta Novel

- 83.2 Molecular chaperone with ATPase activity

20 P06151 L-lactate dehydrogenase A chain Known

[Cooper

et al.

2010]

20 P08249 Malate dehydrogenase, Nove

Novel - $\quad 35.5 \quad$ Role in glycolysis, oxidation reduction mitochondrial

31 P17751 Triosephosphate isomerase Novel - 26.6 Glycolysis, fatty acid biosynthesis, gluconeogenesis, lipid synthesis

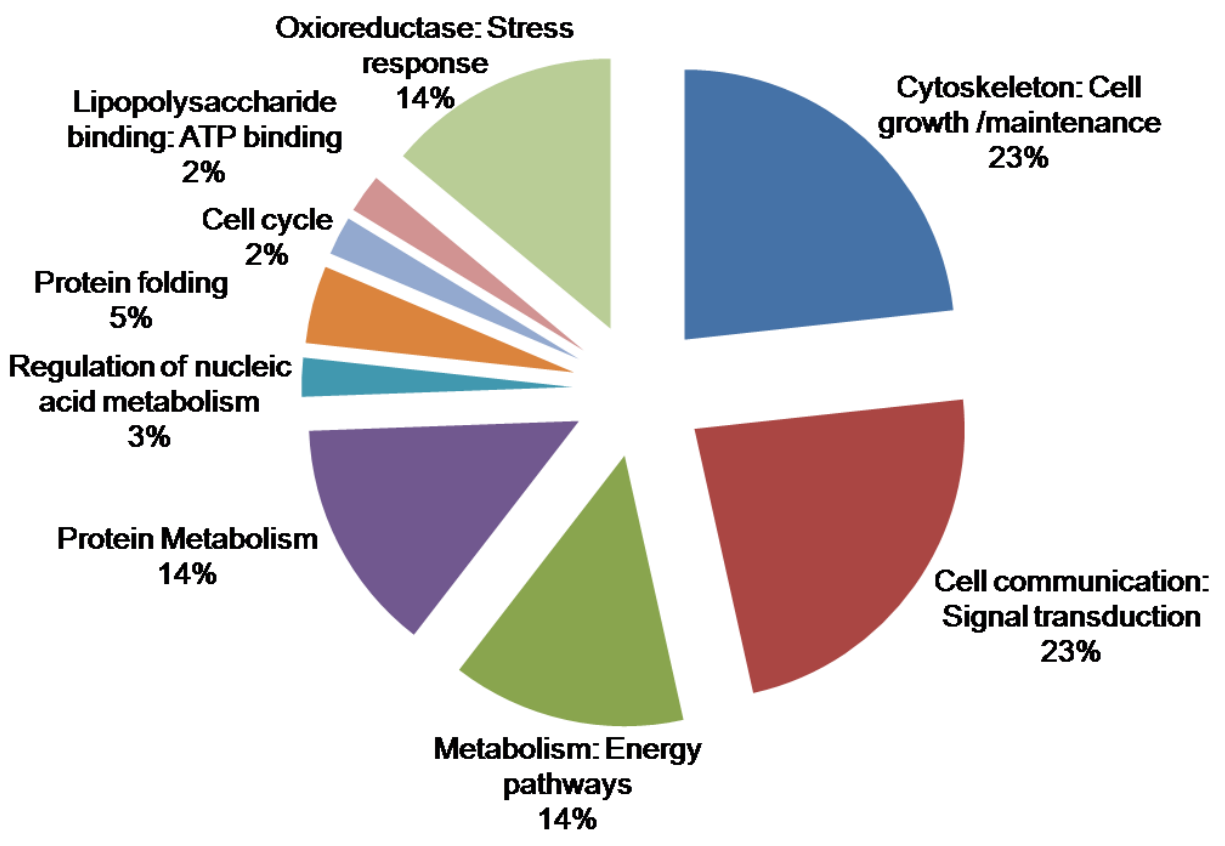

\section{Figure 11 The functional categorization of identified interacting partners of $\operatorname{PrP}^{\mathrm{C}}$ :}

Interacting proteins identified by C-Terminus One-STrEP-tag purification were identified by Q-TOF MSMS analysis. The biological functions are assigned as in ExPASy protein database (http://expasy.org/) and Human Protein Reference Database [Keshava Prasad et al. 2009]. 


\subsubsection{Binding of C-terminus One-STrEP-tag $\mathrm{PrP}^{\mathrm{C}}$ by interacting partners}

In order to further confirm the observations from the One-STrEP-tag purification system, TCL prepared from transiently $\mathrm{PrP}^{\mathrm{C}}$ transfected neuronal HpL3-4 cells and control $\mathrm{PrP}^{-/-}$transfected were reverse co-immunoprecipitated with Rab7a, Arf1 and $\operatorname{PrP}^{C}$ specific antibodies using G-protein coupled magnetic beads Eluates from this reverse co-immunoprecipitation revealed a significant $\operatorname{PrP}^{C}$ signal at $27 \mathrm{kDa}$ to $37 \mathrm{kDa}$ (Figure 12A). Figure 12B-D showed the reverse co-immunoprecipitation results with $\operatorname{PrP}^{\mathrm{C}}$, Rab7a, Arf1 and alpha-tubulin1 antibodies, providing additional evidence for their interaction.
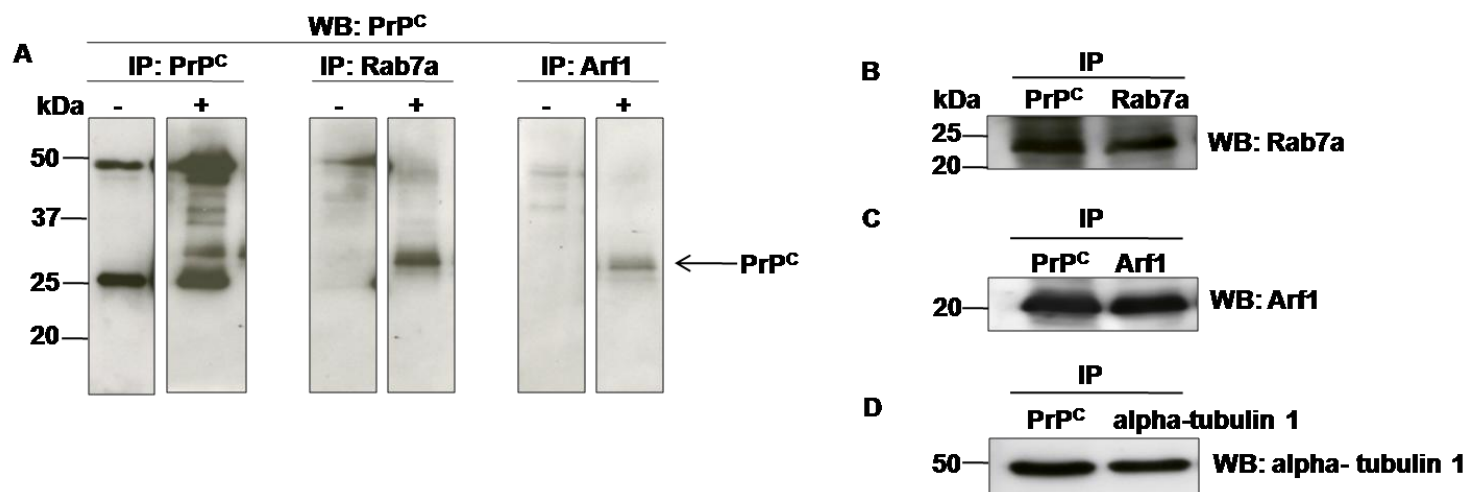

Figure $12 \operatorname{PrP}^{C}$ interacts with Rab7a, Arf1 and alpha-tubulin 1: (A) TCL were coimmunoprecipitated (IP) with $3 \mathrm{~F} 4 \mathrm{PrP}^{\mathrm{C}}$ (Lane1 $\mathrm{PrP}^{-/}$transfected and lane $2 \mathrm{PrP}^{+/ /}$transfected), Rab7a (lane $3 \mathrm{PrP}^{-/}$transfected and lane $4 \mathrm{PrP}^{+/+}$transfected) and Arf1 (Lane $5 \mathrm{PrP}^{-/}$transfected and lane 6 $\mathrm{PrP}^{+/+}$transfected) and immunoblotted with Saf70 $\mathrm{PrP}^{\mathrm{C}}$ antibody. (B) IP with $3 \mathrm{~F} 4 \mathrm{PrP}^{\mathrm{C}}$ (Lane1), Rab7a (lane 2) and immunoblotted with Rab7a antibody, (C) IP with 3F4 $\operatorname{PrP}^{\mathrm{C}}$ (Lane1), Arf1 (lane 2) and immunoblotted with Arf1 antibody, (D) IP with $3 F 4 \operatorname{PrP}^{\mathrm{C}}$ (Lane1), alpha-tubulin 1 (lane 2) and immunoblotted with alpha-tubulin 1 antibody. 


\subsection{Characterization of interacting partners}

\subsubsection{Rab7a and PrP ${ }^{\mathrm{C}}$}

One-STrEP-tag purification and co-immunoprecipitation assays provided evidence that Rab7a might be an interacting partner of $\operatorname{PrP}^{\mathrm{C}}$. To further check the potential interaction and influence of Rab7a on $\operatorname{PrP}^{\mathrm{C}}$ localization and expression, $\operatorname{PrP}^{\mathrm{C}}$ was transiently expressed in HpL3-4 $\mathrm{PrP}^{\mathrm{C}}$ knockout. In addition, SH-SY5Y cells stably expressing $\operatorname{PrP}^{\mathrm{C}}$ were examined. $\operatorname{PrP}^{\mathrm{C}}$ showed colocalization with $\mathrm{Rab7a}$ in the cytosolic area. In order to quantify the extent of colocalization, Imagej (WCIF plugin) software was used (Figure 13). Colocalization in fluorescence imaging characterizes the overlap extent between two different fluorescent labels with different emission wavelengths. The detection of fluorescence signals from two differently labeled proteins within the same voxel (three-dimensional pixel) determines that these proteins are located in the same area or very near to each other. Two perfectly colocalized fluorescence signals, each displayed on separate $x$ and $y$ axes, will generate a scatter plot wherein the points fall in a line at $45^{\circ}$ to either axis. In the situation of noncolocalized molecules, the resulting scatter plot reveals each color along its own axis, with no overlap at $45^{\circ}$. Quantification of co-localization of Rab7a and $\operatorname{PrP}^{\mathrm{C}}$, using the distribution of fluorescence intensities in the scatter plots showed a partial colocalization between Rab7a and $\operatorname{PrP}^{\mathrm{C}}$ (Figure 13).

Pearson's correlation coefficient $r p(-1 \leq r p \leq 1)$ was used to measure the relatedness of two fluorescence channels, where values of 0 indicate no relatedness, whereas values $>0$ indicate a relatedness between the two fluorescence channels. On the basis of positive correlation coefficients for all analyzed pairs of fluorescence channels, further calculations were permissible for colocalization coefficients, M1 and M2, which express the contribution of each fluorescence channel to the pixels of interest. Values of colocalization coefficients range between 0 and 1. A value of 0 indicates that none of the signal within thresholds in that channel colocalizes with the other channel. A value of 1 indicates that the entire signal within thresholds in that channel colocalizes with the other channel. Results of Pearson's correlation coefficient of colocalization demonstrated a partial colocalization between Rab7a and $\operatorname{PrP}^{\mathrm{C}}$ (Table 9). 
$\operatorname{PrP}^{\mathrm{C}}$ distribution was then evaluated after depleting Rab7a expression using the siRNA duplex. Approximately 70-75\% Rab7a expression depletion was achieved in transiently and stably $\mathrm{PrP}^{\mathrm{C}}$ expressed HpL3-4 and SH-SY5Y cells, respectively (Figure 13A). The immunoflurescence results demonstrated that a significant fraction of $\operatorname{PrP}^{C}$ accumulated as a punctuated form and that the localization pattern of $\operatorname{PrP}^{\mathrm{C}}$ staining is dramatically altered in Rab7a depleted HpL3-4 cells (Figure 13D) as compared to cells treated similarly but without siRNA (control) (Figure 13C). Immunoblot analysis showed a significant $\left({ }^{*} P<0.05\right)$ increase of $\operatorname{PrP}^{C}$ levels in HpL3-4 cells after Rab7a knockdown in comparison to similar knockdown in $\mathrm{PrP}^{-/-}$control cells (Figure 14A and $\mathrm{B}$ ). These Rab7a siRNA knockdown results were confirmed in SH-SY5Y stably $\operatorname{PrP}^{\mathrm{C}}$ expressing cells (Figure $14 \mathrm{C}$ ). The increase in the $\mathrm{PrP}^{\mathrm{C}}$ expression was confirmed in SH-SY5Y $\mathrm{PClneo}$ endogenously and $\mathrm{SH}-\mathrm{SY} 5 \mathrm{Y}$ stable $\mathrm{PrP}^{\mathrm{C}}$ expressing cells $\left({ }^{*} \mathrm{P}<0.05\right.$; Figure $14 \mathrm{~A}, \mathrm{C})$. Subsequent immunoblots showed the influence of Rab7a knockdown on the expression of Arf1 in cells with and without Rab7a knockdown. The Arf1 was markedly decreased by Rab7a siRNA knockdown in HpL3-4 PrPC ${ }^{\mathrm{C}}$ cells (Figure 14A-B) as well as in SH-SY5Y PrPC stable cells (Figure 14A and C). 


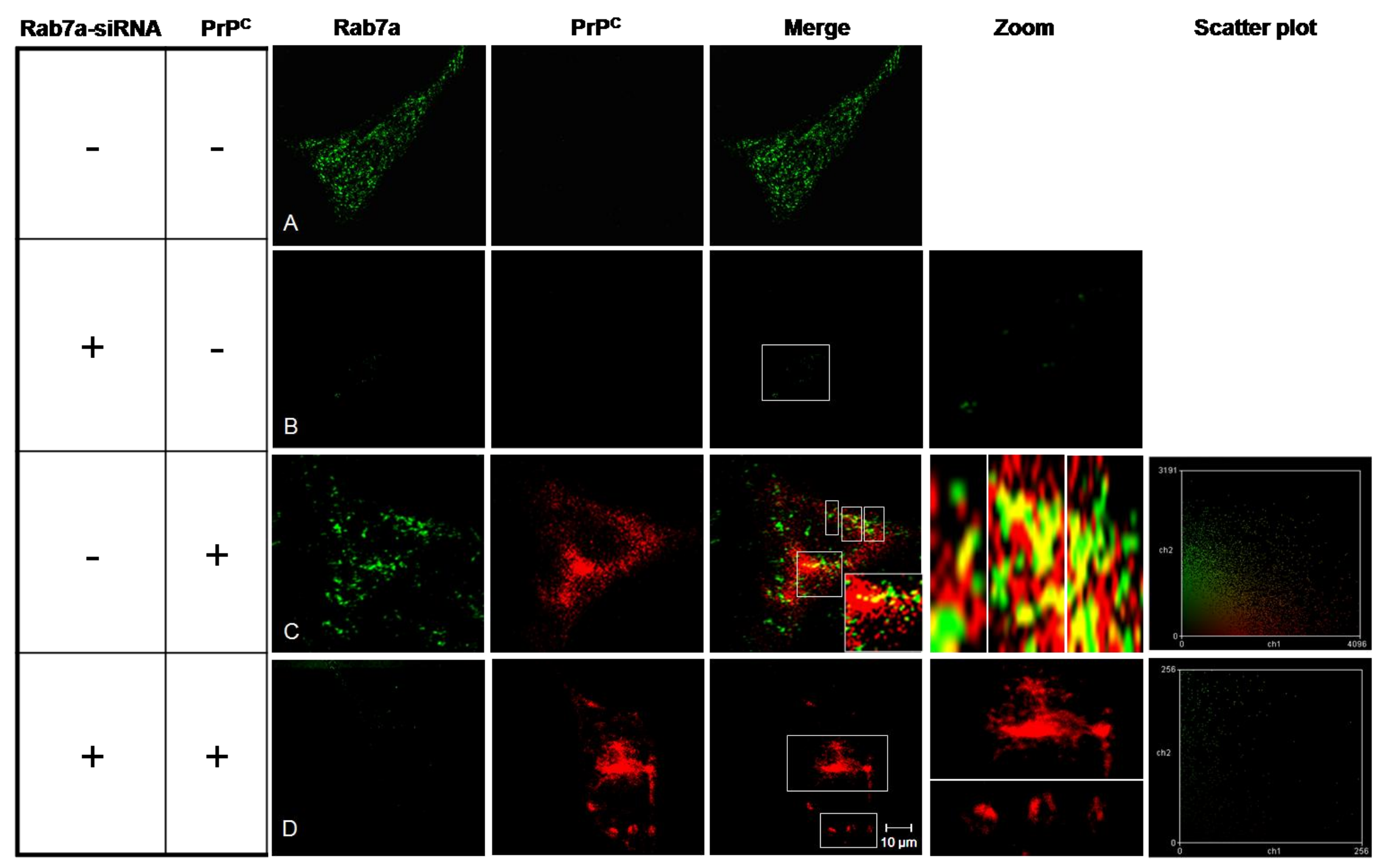

Figure 13 Effect of Rab7a depletion on $\operatorname{PrP}^{\mathrm{C}}$ localization: HpL3-4 $\operatorname{PrP}^{\mathrm{C}}$ knockout cells were treated with siRNA duplex (100 nM) to target Rab7a and $\mathrm{PrP}^{\mathrm{C}}$. $48 \mathrm{H}$ after transfection, $\operatorname{PrP}^{\mathrm{C}}$ and Rab7a expression was analyzed by using $3 \mathrm{~F} 4$ anti-PrP $(\mathrm{red})$ and anti-Rab7a 
(green), antibodies. (A) HpL3-4 $\mathrm{PrP}^{\mathrm{C}}$ knockout cells transfected with non targeting siRNA (negative control) and $\operatorname{PrP}^{-/}$, (B) HpL3-4 PrP ${ }^{C}$ knockout cells transfected with Rab7a siRNA and $\operatorname{PrP}^{+/+}$. $\operatorname{PrP}^{\mathrm{C}}$ and Rab7a distribution was analyzed by using $3 \mathrm{~F} 4 \mathrm{PrP}^{\mathrm{C}}$ (red) and anti-Rab7a (green) antibodies. At least 25 cells were observed per condition per experiment for an equal exposure time. The scatter plots of the individual pixels from paired images. The threshold levels of red on $x$-axis and green signals on $y$-axis determined the overlapping yellow region (midle). Quantification of colocalization was determined by Zeiss LSM 510 (version 3.2) and Imagej (WCIF plugin) softwares.

Table 9 Rab7a partially colocalizes with PrP': Pearson's correlation coefficient $r_{\mathrm{p}}(-1 \leq$ $\left.r_{\mathrm{p}} \leq 1\right)$ demonstrated partial colocalization in HpL3-4 $\operatorname{PrP}^{\mathrm{C}}$ knockout cells transfected with non targeting siRNA and $\operatorname{PrP}^{\mathrm{C}}$. Colocalization coefficients, $M 1$ and $M 2$ ranged between 0 and 1 , showed partial colocalized pixels of interest with in each channel.

\begin{tabular}{ccccc}
\hline Rab-siRNA & PrP $^{\mathrm{C}}$ & rp & $\begin{array}{c}\text { Coloc. Coefficient } \\
\text { PrP }^{\mathrm{C}}(\boldsymbol{M 1})\end{array}$ & $\begin{array}{c}\text { Coloc. Coefficient Rab7a } \\
\text { (M2) }\end{array}$ \\
\hline- & + & 0.121 & 0.592 & 0.239 \\
+ & + & -0.068 & 0.006 & 0.339 \\
\hline
\end{tabular}


A

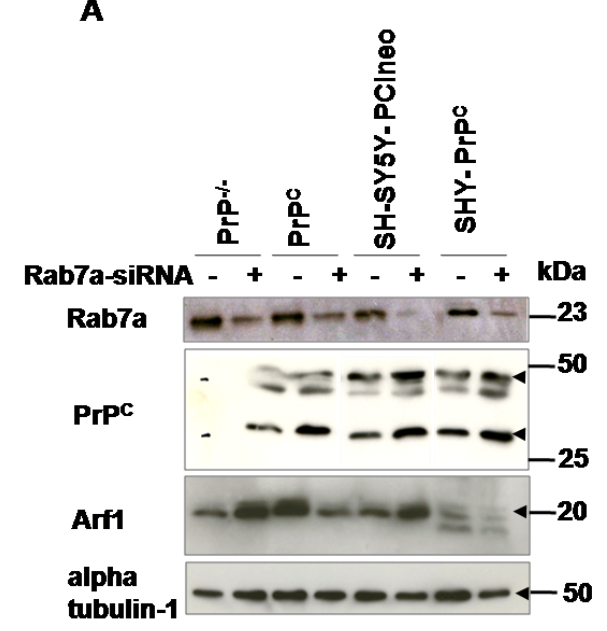

Figure 14 Effect of Rab7a depletion on $\operatorname{PrP}^{\mathrm{C}}$, Arf1 and alpha-tubulin 1 expression: HpL3-4 PrP ${ }^{C}$ knock out with transient $\mathrm{PrP}^{\mathrm{C}}$ expressing and $\mathrm{SH}-\mathrm{SY} 5 \mathrm{Y}$ stable $\mathrm{PrP}^{\mathrm{C}}$ expressing cells were transfected with siRNA duplex $(100 \mathrm{nM})$ to target Rab7a. (A) $\operatorname{PrP}^{\mathrm{C}}$, Arf1, alpha-tubulin 1 and Rab7a expression was analyzed after $48 \mathrm{H}$ of transfection by immnoblotting using specific Saf70 $\mathrm{PrP}^{\mathrm{C}}$, Arf1, alpha-tubulin1 and Rab7a antibodies. (B, C) Densitometry
B

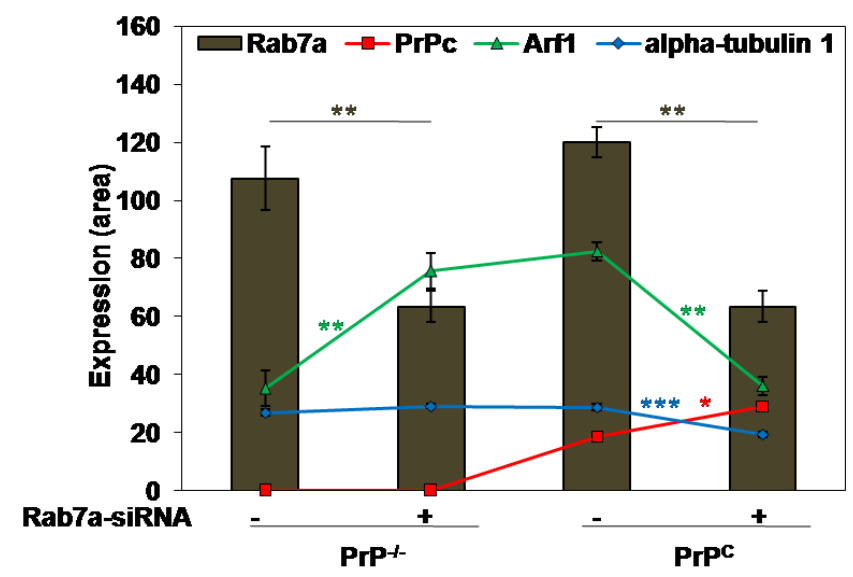

C

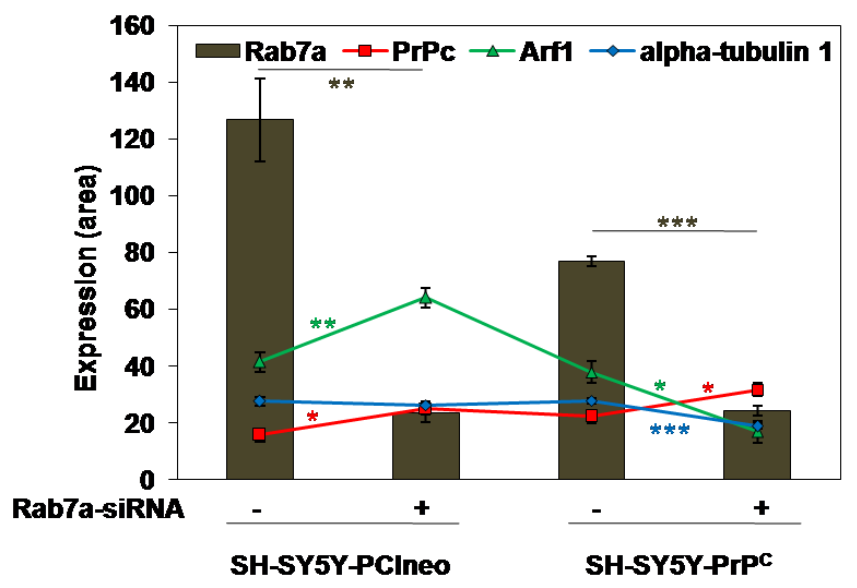
analysis from four independent $( \pm S D)$ immnoblotting experiments and the significance was calculated by student's t-test $\left({ }^{*} P<0.05,{ }^{* \star} P<0.01,{ }^{* \star *} P<0.001\right)$.

To determine the subcellular localization of $\operatorname{PrP}^{\mathrm{C}}$ in these siRNA knock down of Rab7a HpL3-4 cells, an immunofluorescence experiment with co-staining of $\operatorname{PrP}^{\mathrm{C}}$ and Rab9 (late endosomal marker [Russell et al. 2006] was performed. Interestingly accumulated $\operatorname{PrP}^{\mathrm{C}}$ higly co-localized with Rab9 positive compartments (Figure 15). Figure 15 showed respective scatter plots generated from representative images. Rab9 (green) and $\operatorname{PrP}^{\mathrm{C}}$ (red) was largely overlapping, as indicated in the scatter plot at $45^{\circ}$ (Figure 15B) as compared to control HpL3-4 $\mathrm{PrP}^{\mathrm{C}}$ knockout cells transfected with non 
targeting siRNA and $\operatorname{PrP}^{\mathrm{C}}$. Calculations of Pearson's correlation coefficient of colocalization demonstrate that colocalization between $\operatorname{PrP}^{\mathrm{C}}$ and Rab9 increased after Rab7a-siRNA treatment (Table 10).
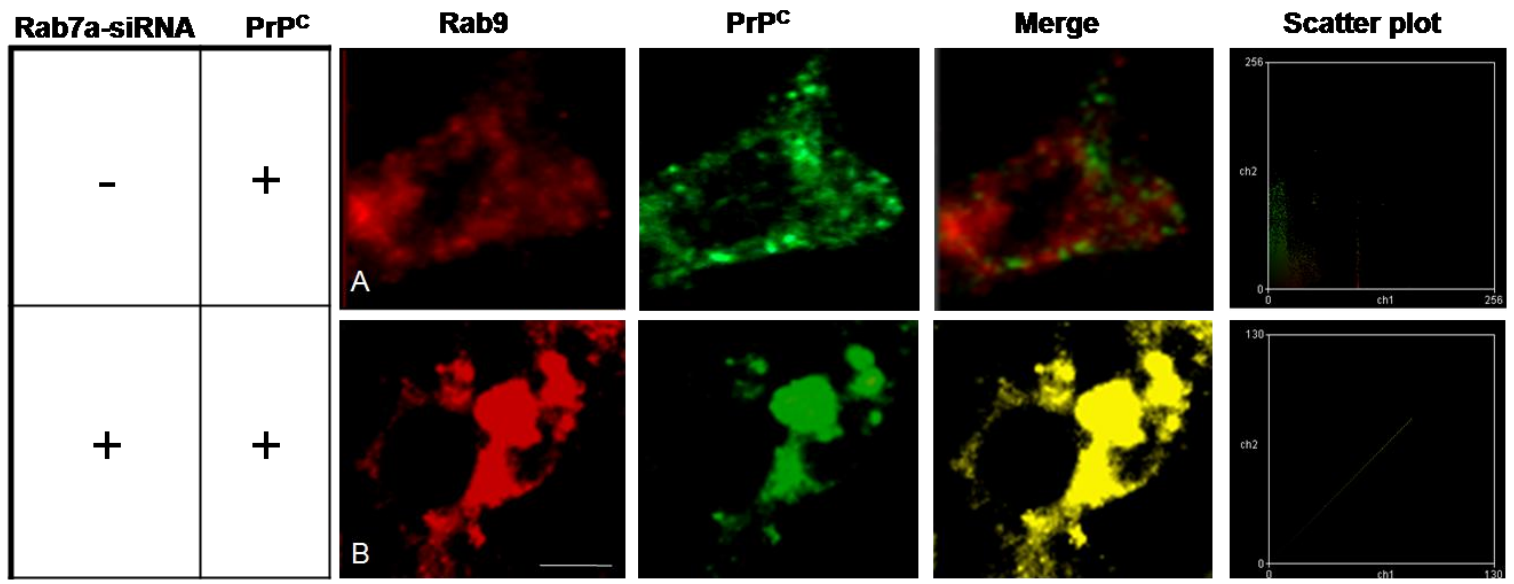

Figure 15 Effect of Rab7a depletion on PrP $^{\mathrm{C}}$ localization: HpL3-4 $\mathrm{PrP}^{\mathrm{C}}$ knockout cells transiently transfected $(48 \mathrm{H})$ with $\operatorname{PrP}^{C}$ and treated with siRNA (100 nM) to target Rab7a. $\operatorname{PrP}^{C}$ and late endosomal marker Rab9 expression were analyzed using $3 \mathrm{~F} 4$ anti-PrP ${ }^{\mathrm{C}}$ (red) and anti-Rab9 (green), antibodies. (A) HpL3-4 PrP ${ }^{\mathrm{C}}$ knockout cells transfected with non targeting siRNA and $\operatorname{PrP}^{\mathrm{C}}$ (B) HpL3-4 $\operatorname{PrP}^{\mathrm{C}}$ knockout cells co-transfected with $\operatorname{PrP}^{\mathrm{C}}$ and Rab7a siRNA. At least 25 cells were observed per condition per experiment for an equal exposure time (Scale bar: $10 \mu \mathrm{m}$ ). The scatter plots of the individual pixels are from paired images. The threshold levels of red on $x$-axis and green signals on $y$-axis determined the overlapping yellow region. Quantification of colocalization was determined by Imagej (WCIF plugin) software.

Table 10 Rab9 colocalizes with $\mathrm{PrP}^{\mathrm{C}}$ in Rab7a depleted HpL3-4 cells: Pearson's correlation coefficient $r_{\mathrm{p}}\left(-1 \leq r_{\mathrm{p}} \leq 1\right)$ demonstrated high colocalization between Rab9 and $\mathrm{PrP}^{\mathrm{C}}$ in HpL3-4 PrP ${ }^{\mathrm{C}}$ knockout cells transfected with Rab7a-siRNA and $\operatorname{PrP}^{\mathrm{C}}$. Colocalization coefficients, $M 1$ and $M 2$ ranged between 0 and 1, showed high colocalized pixels of interest within each channel.

\begin{tabular}{ccccc}
\hline Rab7a-siRNA & PrP $^{\mathrm{C}}$ & rp & $\begin{array}{c}\text { Coloc. Coefficient } \\
\operatorname{PrP}^{\mathrm{C}} \text { (M1) }\end{array}$ & $\begin{array}{c}\text { Coloc. Coefficient } \\
\text { Rab9 (M2) }\end{array}$ \\
\hline- & + & 0.306 & 0.679 & 0.793 \\
+ & + & 0.779 & 0.970 & 1.000 \\
\hline
\end{tabular}


In order to see if transiently expressed $\operatorname{PrP}^{C}$ has similar characteristics to the proteinase $\mathrm{K}(\mathrm{PK})$ resistant $\mathrm{PrP}^{\mathrm{Sc}}$ form, the total cellular lysate of HpL3-4 cells containing transiently transfected $\mathrm{PrP}^{\mathrm{C}}$ and treated with Rab7a-siRNA, were digested with PK $(10 \mu \mathrm{g} / \mathrm{ml})$ and analyzed by western blot using Saf70 antibody. The results demonstrated that the accumulated $\operatorname{PrP}^{\mathrm{C}}$ does not acquire the $\mathrm{PK}$ resistant form, at least not within the $48 \mathrm{H}$ tested (Figure 16).

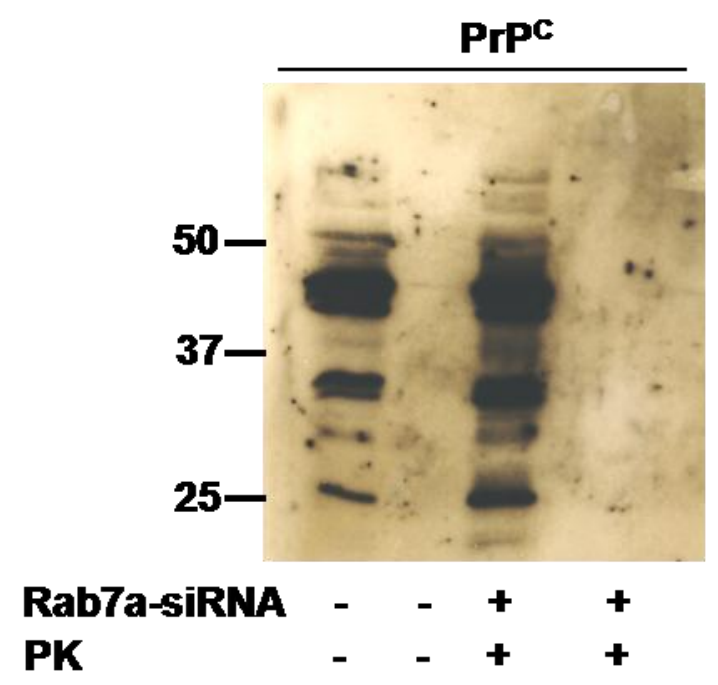

Figure 16 Figure 16 PK-digestion of PrP ${ }^{C}$ under Rab7a knockdown HpL3-4

cells: HpL3-4 PrP ${ }^{C}$ knockout cells were transfected with $\operatorname{PrP}^{\mathrm{C}}$ and siRNA to target Rab7a protein. SiRNAs (100 nM) were cotransfected with C-terminus One-STrEP-tag $\mathrm{PrP}^{\mathrm{C}}$ into cultured HpL3-4 PrP $\mathrm{P}^{\mathrm{C}}$ knockout cells. The TCL was treated with $10 \mu \mathrm{g} / \mathrm{ml} \mathrm{PK}$ and PrP ${ }^{\mathrm{C}}$ was analyzed by immunoblot using Saf70 antibody.

\subsubsection{Arf1 and PrP ${ }^{\mathrm{C}}$}

One-STrEP-tag purification and co-immunoprecipitation assays also identified Arf1 as a novel potential interacting partner of $\operatorname{PrP}^{\mathrm{C}}$. Arf1 is an activator of phospholipase $\mathrm{D}$ and plays an important role in vesicular trafficking. To demonstrate the effects of Arf1 on $\mathrm{PrP}^{\mathrm{C}}$ expression and localization, HpL3-4 $\mathrm{PrP}^{\mathrm{C}}$ transfected and $\mathrm{SH}$ SY5Y PrPC stably expressing cells were treated with different concentrations of Brefeldin A (BFA). BFA is an inhibitor of intracellular protein transport and is commonly used to demonstrate the role of Arf1 in the morphology of the Golgi apparatus and recruitment of coat proteins to the Golgi [Volpicelli-Daley et al. 2005]. Immunofluorescence data showed significant changes in $\mathrm{PrP}^{\mathrm{C}}$ localization as compared to untreated cells (Figure 17). Quantification of the co-localization of Arf1 and $\operatorname{PrP}^{\mathrm{C}}$ by using the distribution of fluorescence intensities in the scatter plots demonstrated a 
partial colocalization between $\operatorname{Arf1}$ and $\operatorname{PrP}^{C}$ (Figure 17). Pearson's correlation coefficient $r p(-1 \leq r p \leq 1)$ also demonstrated partial colocalization between Arf1 and $\operatorname{PrP}^{\mathrm{C}}$ (Table 11). The long term exposure to BFA (24 H of $1 \mu \mathrm{g} / \mathrm{ml}$ BFA) showed the accumulation of $\mathrm{PrP}^{\mathrm{C}}$ and drastically altered localization (Figure 17D) as compared to the control cells (Figure 17B). In contrast; however, after $1.5 \mathrm{H}$ of $1 \mu \mathrm{g} / \mathrm{ml} \mathrm{BFA}$ treatment cells showed dispersed co-localization of $\operatorname{PrP}^{\mathrm{C}}$ with Arf1 (Figure $17 \mathrm{C}$ and E). The extent of colocalization decreased after BFA treatment as compared to the control, untreated cells (Table 11).

The immunoblot analysis showed that the Arf1 expression was significantly decreased after BFA treatment in HpL3-4 cells transiently transfected with $\mathrm{PrP}^{\mathrm{C}}$ (Figure $18 \mathrm{~A}-\mathrm{B}$ ) as well as in $\mathrm{SH}-\mathrm{SY} 5 \mathrm{Y} \mathrm{PrP}^{\mathrm{C}}$ stably expressing cells (Figure 18A-C). Immunoblotting experiments showed a significant decrease of $\operatorname{PrP}^{\mathrm{C}}$ concentrations in BFA treated cells $\left({ }^{*} \mathrm{P}<0.05,{ }^{* *} \mathrm{P}<0.01,{ }^{* *} \mathrm{P}<0.001\right)$ in comparison to control cells (Figure 18A-C). 


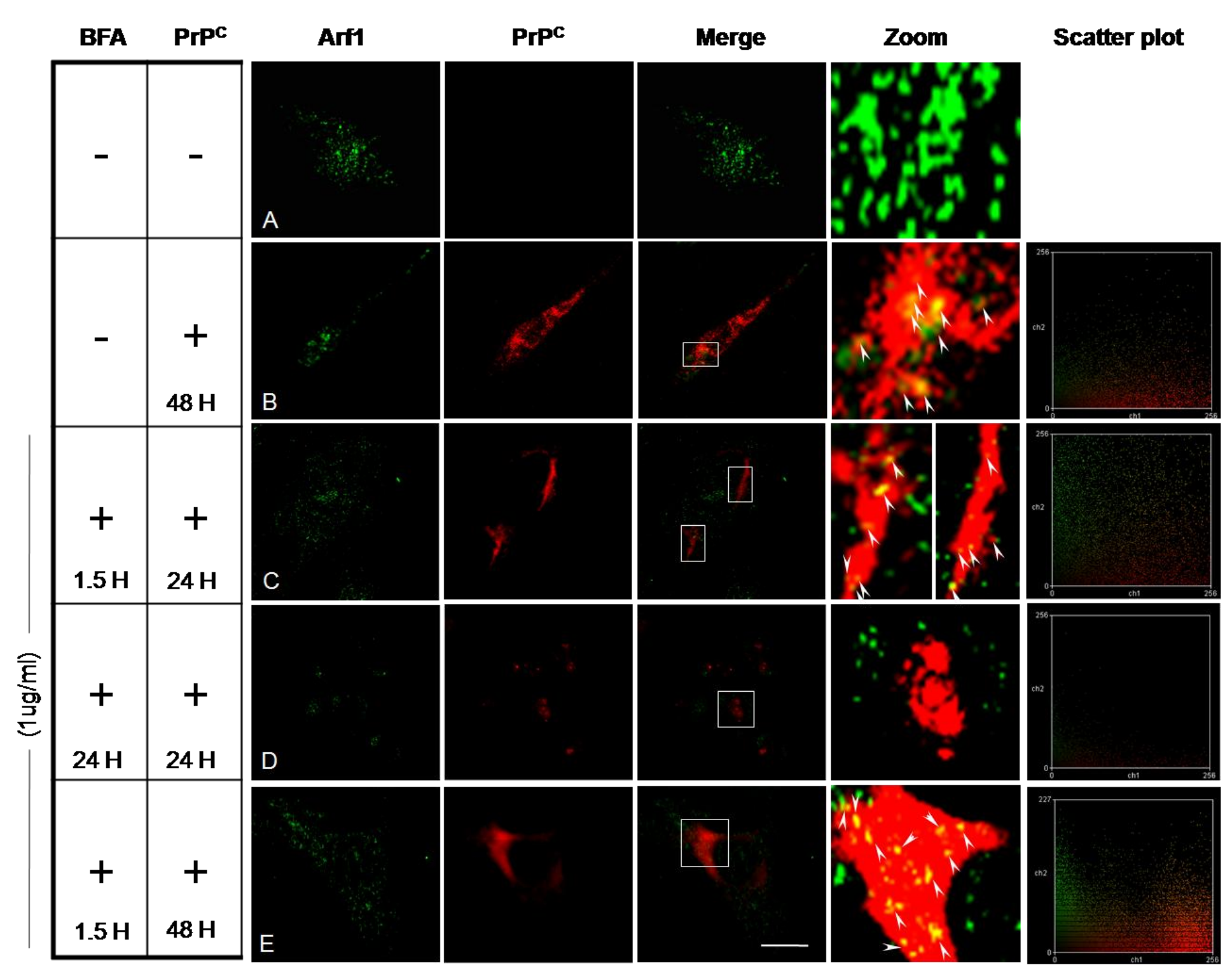

Figure

17

Effect of BFA

on Arf1 and

PrP ${ }^{C}$

localization:

HpL3-4 PrP

knockout cells

were transiently

transfected with $\mathrm{PrP}^{+/+}$or $\mathrm{PrP}^{-/-}$and treated with BFA $(1 \mu \mathrm{g} / \mathrm{ml}) \quad$ for different time intervals $\quad(\mathrm{A})$ untreated HpL3-4 $\mathrm{PrP}^{-/-}$transfected cells (B) untreated HpL3-4 PrP transfected cells, (C) $1.5 \mathrm{H}$ of BFA treatment after 24 $\mathrm{H}$ of $\mathrm{PrP}^{\mathrm{C}}$ transient transfection (D) 24

$\mathrm{H}$ of BFA treatment after $24 \mathrm{H}$ of $\operatorname{PrP}^{\mathrm{C}}$ transient transfection, (E) $1.5 \mathrm{H}$ of BFA treatment after $48 \mathrm{H}$ of $\operatorname{PrP}^{\mathrm{C}}$ transient transfection. PrP ${ }^{\mathrm{C}}$ and Arf1 distribution was analyzed by using $3 \mathrm{~F} 4$ anti- $\mathrm{PrP}^{\mathrm{C}}$ (red) and anti-Arf1 (green) antibodies. At least 25 cells were observed per condition per experiment for an equal exposure time (Scale bar: $10 \mu \mathrm{m}$ ). The scatter plots of the individual pixels from paired images were generated by Imagej (WCIF plugin) software. 
Table 11 Arf1 partially colocalizes with PrPC: Pearson's correlation coefficient $r_{\mathrm{p}}\left(-1 \leq r_{\mathrm{p}} \leq 1\right)$ demonstrated partial colocalization (0.142) between Afr1 and $\mathrm{PrP}^{\mathrm{C}}$ in HpL3-4 PrP ${ }^{\mathrm{C}}$ knockout cells transfected with $\mathrm{PrP}^{\mathrm{C}}$ and without BFA treatment. $1.5 \mathrm{H}$ and $24 \mathrm{H}$ of BFA treatment showed less colocalization as compared to control untreated cells. Colocalization coefficients, M1 and M2 ranged between 0 and 1 , showing partial colocalized pixels of interest within each channel.

\begin{tabular}{ccccc}
\hline $\begin{array}{c}\text { BFA } \\
(\mathbf{1 u g} / \mathrm{ml})\end{array}$ & PrP $^{\mathrm{C}}$ & rP & $\begin{array}{c}\text { Coloc. Coefficient PrP } \\
(\boldsymbol{M} 1)\end{array}$ & $\begin{array}{c}\text { Coloc. Coefficient Afr1 } \\
(\boldsymbol{M} 2)\end{array}$ \\
\hline- & + & 0.142 & 0.359 & 0.662 \\
$+1.5 \mathrm{H}$ & + & 0.028 & 0.242 & 0.224 \\
$+24 \mathrm{H}$ & + & -0.003 & 0.359 & 0.140 \\
$+1.5 \mathrm{H}$ & + & 0.048 & 0.472 & 0.412 \\
\hline
\end{tabular}


A

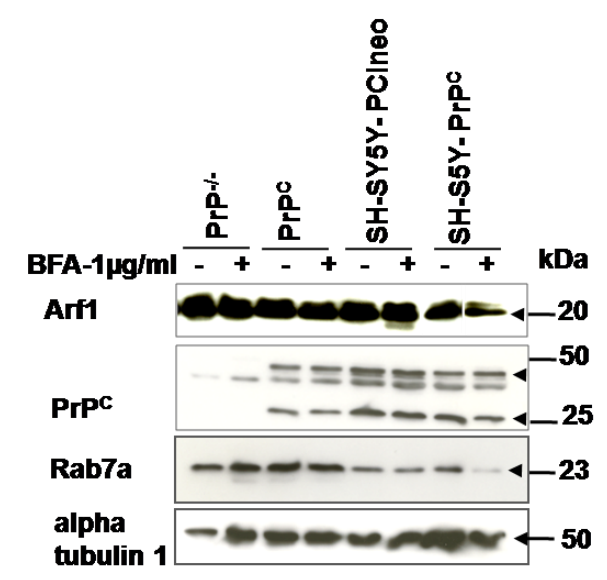

Figure 18 Effect of BFA treatment on PrP ${ }^{\mathrm{C}}$, Rab7a, Arf1 and alpha-tubulin 1

expression: HpL3-4 $\mathrm{PrP}^{\mathrm{C}}$ knockout with $48 \mathrm{H}$ of transient $\mathrm{PrP}^{\mathrm{C}}$ expressing and $\mathrm{SH}-\mathrm{SY} 5 \mathrm{Y}$ stable $\mathrm{PrP}^{\mathrm{C}}$ expressing cells were treated with $1 \mu \mathrm{g} / \mathrm{ml}$ BFA for 1.5 H. (A) PrPC, Rab7a, Arf1 and alphatubulin 1 expression was analyzed by immnoblotting using specific Saf70 $\mathrm{PrP}^{\mathrm{C}}$, Rab7a, Arf1 and alpha-tubulin1 antibodies. $(B, C)$ Densitometry analysis from four independent $( \pm S D)$ immnoblotting experiments where the significance was calculated by student's t-test $\left({ }^{*} \mathrm{P}<0.05,{ }^{* *} \mathrm{P}<0.01,{ }^{* * *} \mathrm{P}<0.001\right)$.

\subsubsection{Rab7a/Arf1 interdependent role}

To search for the molecular link between Rab7a and Arf1 during sorting, candidate Rab7a was depleted by siRNA interference, and the resulting phenotypes were examined. The expression of Arf1 was markedly decreased by Rab7a knockdown in HpL3-4 PrP ${ }^{C}$ cells and also in the control SH-SY5Y PrPC stable cell line (Figure 14AC). Rab7a activity was then monitored during BFA treatment. No significant influence was observed on Rab7a expression by BFA treatment (Figure 18A-C). 


\subsubsection{Microtubule fate in $\operatorname{PrP}^{\mathrm{C}}$, Rab7a and Arf1 internalization}

$\mathrm{PrP}^{\mathrm{C}}$ binds directly to tubulin and this interaction leads to the inhibition of microtubule formation [Nieznanski et al. 2005; Nieznanski 2009] which is a necessary component of vesicle transportation for endosome movement [Nielsen et al. 1999; Nielsen et al. 2001; Bananis et al. 2000; Bananis et al. 2004; Matteoni and Kreis 1987]. When cells were treated for $3 \mathrm{H}$ with nocodazole, a microtubule polymerization interfering agent, an altered localization pattern of $\operatorname{PrP}^{\mathrm{C}}$ was observed; more towards the cytosolic region of the cell (Figure 19B). The quantification of the co-localization of alpha-tubulin 1 and $\mathrm{PrP}^{\mathrm{C}}$ after treatment for $3 \mathrm{H}$ with nocodazole, using the distribution of fluorescence intensities in the scatter plots, demonstrated no significant colocalization between alpha-tubulin 1 and $\operatorname{PrP}^{\mathrm{C}}$ (Figure 19B), as compared to the control, untreated cells (Figure. 19A). Pearson's correlation coefficients of colocalization shown in Table 12 also demonstrated that alpha-tubulin 1 and $\operatorname{PrP}^{\mathrm{C}}$ after $3 \mathrm{H}$ of treatment with nocodazole showed less colocalization. But interestingly after longer exposure to nocodazole $(24 \mathrm{H}), \operatorname{PrP}^{\mathrm{C}}$ and alpha-tubulin 1 were still sharing the same compartments (Figure 19C) which showed that the effects of nocodazole on the organization of microtubules were reversible [Polioudaki et al. 2009]. Pearson's correlations also showed partial colocalization (Table 12).

The TCL from HpL3-4 and SH-SY5Y treated cells were then used to verify PrPC and alpha-tubulin 1 expression. Total expression of alpha-tubulin 1 was not changed significantly after the treatment but the $\operatorname{PrP}^{\mathrm{C}}$ expression was upregulated significantly $\left({ }^{\star} \mathrm{P}<0.05,{ }^{* \star} \mathrm{P}<0.01,{ }^{* *} \mathrm{P}<0.001\right.$ ) after microtubule-disruption (Figure $\left.20 \mathrm{~A}-\mathrm{C}\right)$. The Arf1 and Rab7a protein levels were significantly $\left({ }^{*} \mathrm{P}<0.05,{ }^{* *} \mathrm{P}<0.01,{ }^{* *} \mathrm{P}<0.001\right)$ decreased by microtubule disruption. 


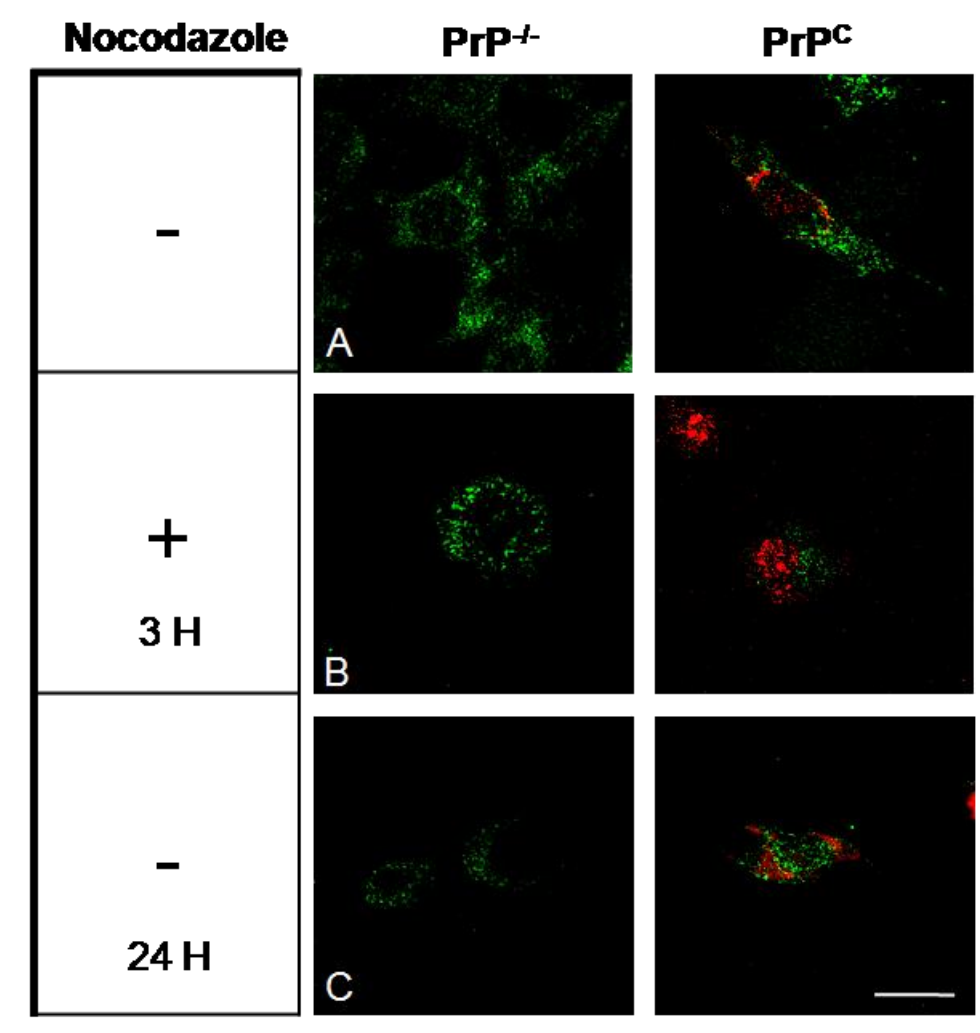

Anti-allpha-tububulin 1//anti-PrPC
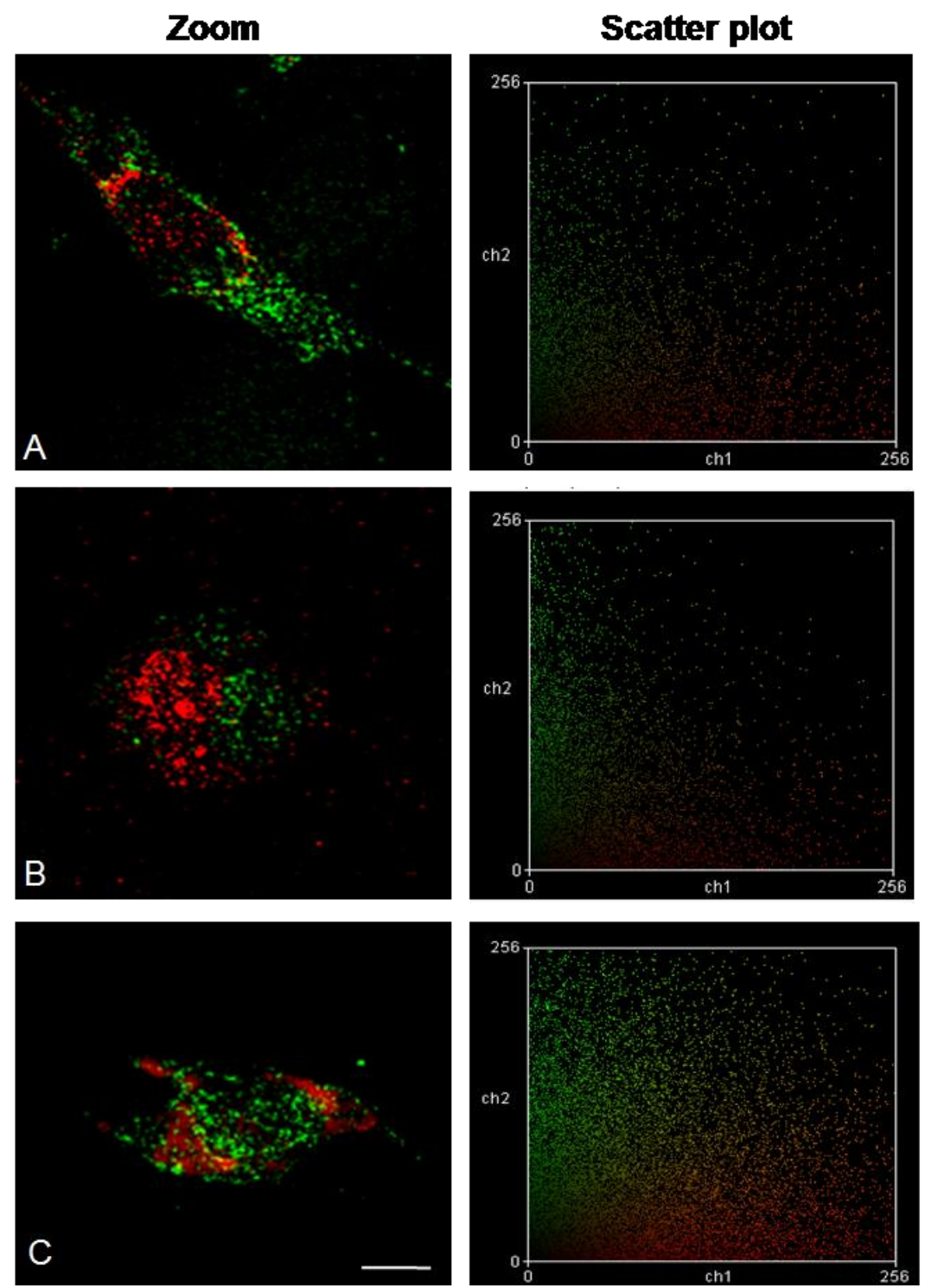

Figure 19 Effect of nocodazole on alpha-tubulin 1 and $\mathrm{PrP}^{\mathrm{C}}$ localization: HpL3-4 PrP ${ }^{\mathrm{C}}$ knockout cells were transfected with $\mathrm{PrP}^{+/+}$or $\mathrm{PrP}^{-/ /}$and treated with norcodazole $(1 \mu \mathrm{mol})$ for different time intervals $(\mathrm{A})$ untreated cells $(\mathrm{B}) 3 \mathrm{H}$ of nocodazole treatment after $24 \mathrm{H}$ of $\operatorname{PrP}^{\mathrm{C}}$ transfection (D) $24 \mathrm{H}$ of nocodazole treatment after $24 \mathrm{H}$ of $\operatorname{PrP}^{\mathrm{C}}$ transfection. $\operatorname{PrP}^{\mathrm{C}}$ and alpha-tubulin 1 distribution were analyzed using $3 \mathrm{~F} 4$ 
anti-PrP ${ }^{C}$ (red) and anti-alpha-tubulin 1 (green) antibodies. At least 25 cells were observed per condition per experiment for an equal exposure time (Scale bar: $10 \mu \mathrm{m}$ ). The scatter plots of the individual pixels from paired images were generated by Imagej (WCIF plugin) software.

Table 12 Alpha-tubulin 1 partially colocalizes with PrPC: Pearson's correlation coefficient $r_{\mathrm{p}}\left(-1 \leq r_{\mathrm{p}} \leq 1\right)$ demonstrated partial colocalization (0.049) between alpha-tubulin 1 and $\operatorname{PrP}^{\mathrm{C}}$ in HpL3-4 $\mathrm{PrP}^{\mathrm{C}}$ knockout cells transfected with $\mathrm{PrP}^{\mathrm{C}}$ but without nocodazole treatment. $3 \mathrm{H}$ and $24 \mathrm{H}$ of nocodazole treatment showed less colocalization as compared to control, untreated cells. Colocalization coefficients, M1 and $M 2$ ranged between 0 and 1, showing partial colocalized pixels of interest within each channel.

\begin{tabular}{ccccc}
\hline $\begin{array}{c}\text { Nocodazole } \\
\text { (1umol) }\end{array}$ & PrP $^{\mathrm{C}}$ & rp & $\begin{array}{c}\text { Coloc. Coefficient PrP } \\
(\boldsymbol{M 1})\end{array}$ & $\begin{array}{c}\text { Coloc. Coefficient alpha- } \\
\text { tubulin 1 (M2) }\end{array}$ \\
\hline- & + & 0.049 & 0.584 & 0.426 \\
$+3 \mathrm{H}$ & + & -0.068 & 0.298 & 0.213 \\
$+24 \mathrm{H}$ & + & 0.006 & 0.554 & 0.533 \\
\hline
\end{tabular}


A

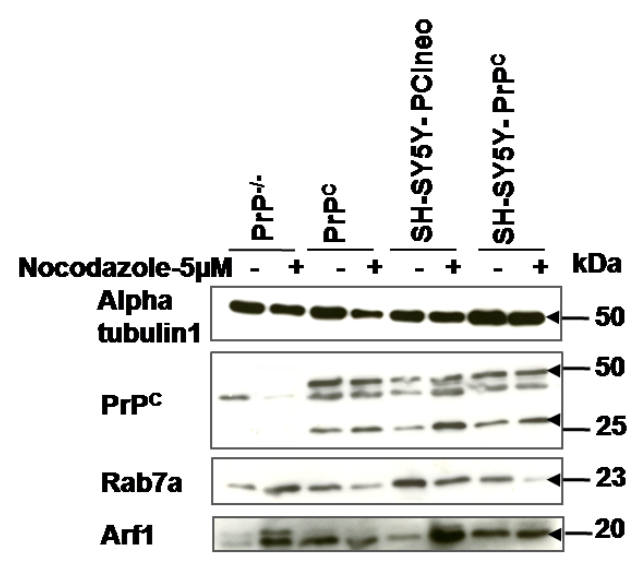

Figure 20 Effect of nocodazole on PrPC , Rab7a, Arf1 and alpha tubulin 1 expression: HpL3-4 PrP ${ }^{\mathrm{C}}$ knockout with $24 \mathrm{H}$ of transient $\operatorname{PrP}^{\mathrm{C}}$ expressing and $\mathrm{SH}-\mathrm{SY} 5 \mathrm{Y}$ stable $\mathrm{PrP}^{\mathrm{C}}$ expressing cells were treated with $5 \mu \mathrm{mol}$ of nocodazole for $24 \mathrm{H}(\mathrm{A}) \mathrm{PrP}^{\mathrm{C}}$, Rab7a, Arf1 and alpha-tubulin 1 expression was analyzed by immnoblotting using specific Saf70 PrP ${ }^{\mathrm{C}}$, Rab7a, Arf1 and alphatubulin1 antibodies. (B, C) Densitometry analysis from four independent $( \pm S D)$ immnoblotting experiments and the significance was calculated by student's t-test $\left({ }^{*} P<0.05,{ }^{* *} P<0.01,{ }^{* * *} P<0.001\right)$.
B

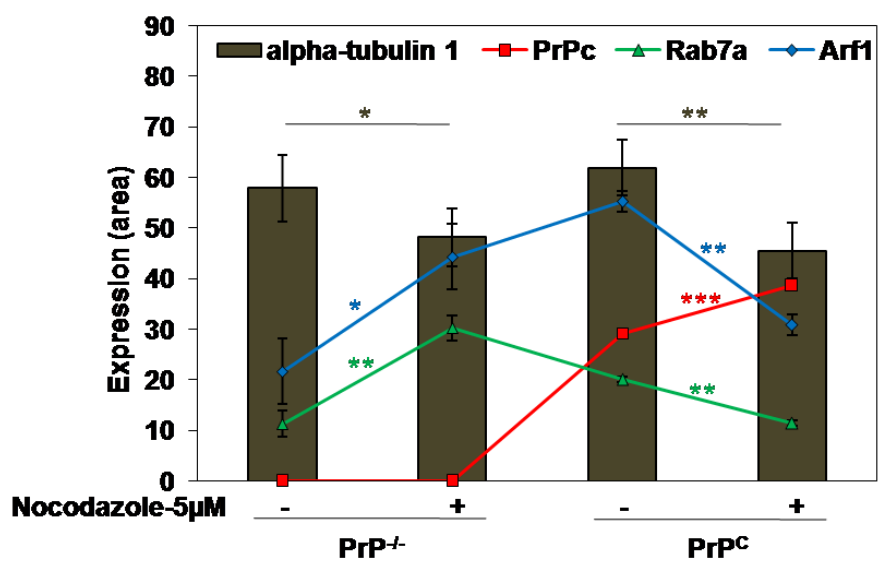

C

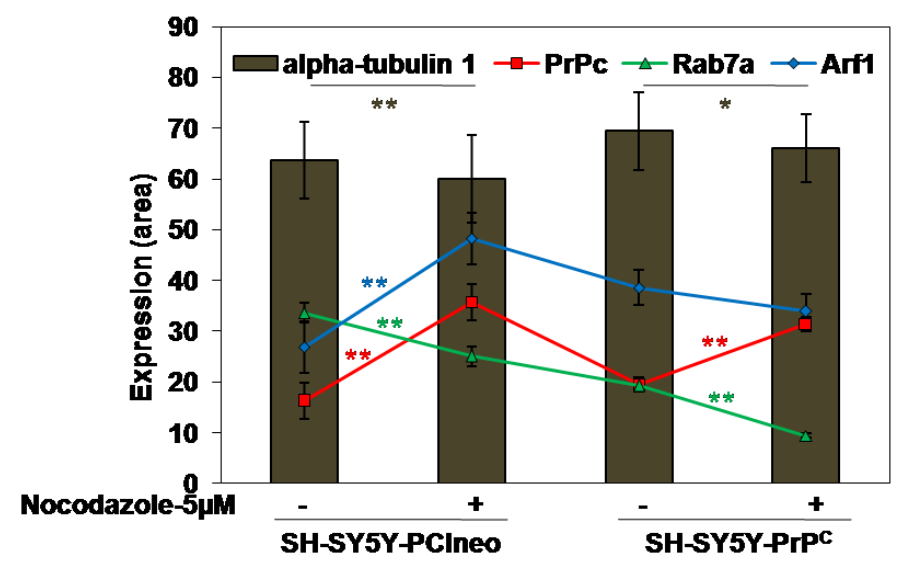




\section{Discussion}

In the last few years, several new $\mathrm{PrP}^{\mathrm{C}}$ interacting proteins have been reported, indicating a growing interest in understanding the physiological function of $\operatorname{PrP}^{\mathrm{C}}$. Towards this goal, protein sequencing techniques have greatly facilitated the identification of proteins and their complexes. Although the sensitivity of mass spectrometry methods is currently sufficient to identify proteins, the isolation of protein complexes still poses serious challenges. Protein complexes need to be isolated from a densely populated cellular environment, in which the complex of interest may represent only a small fraction of the total protein population. Thus, successful purification requires a method that is stringent enough to differentiate the complex of interest from all other proteins in the mixture. On the other hand, the isolation method must also be gentle enough not to compromise the integrity of the complex. A method enabling identification of protein complexes by employing one-step purification would present several advantages. Therefore, the use of a single-step purification system known as the STrEP-tag method was explored for the isolation of interacting proteins from mammalian cells. This protein purification system has previously been shown to allow the rapid, single-step purification of recombinant proteins from bacterial or mammalian cellular lysates [Junttila et al. 2005]. One-STrEP-tag purification enhances the specificity of protein purification; the elution of the STrEP-tag fusion protein is achieved by the addition of desthiobiotin, a reversibly binding derivative of biotin, which binds to the biotin binding pocket on STrEP-Tactin in competition with the STrEP-tag [Junttila et al. 2005]. The short peptide tag, enabling fast and simple one-step purification, coupled with competitive elution, under physiological conditions, are unique characteristics of the STrEP-tag system that make it an ideal candidate method for isolating $\operatorname{PrP}^{\mathrm{C}}$ interacting partners from mammalian cells.

In order to evaluate the usefulness of the STrEP-tag method for purifying protein interacting partners, mammalian expression vectors encoding $\operatorname{PrP}^{\mathrm{C}}$ fused to the OneSTrEP-tag at its C-terminus were first generated. The specificity of these interactions was ensured by comparative purification using control vector without the $\operatorname{PrP}^{C}$ construct $\left(\operatorname{PrP}^{-/}\right)$. Besides reporting a number of novel $\operatorname{PrP}^{\mathrm{C}}$ interacting proteins, several already identified protein partners were identified using these techniques (essentially providing a positive control). Some of the previously described $\mathrm{PrP}^{\mathrm{C}}$-interacting proteins are 
summarized in recent reviews [Linden et al. 2008; Caughey and Baron 2006]. The novel, previously undescribed interacting proteins identified in the present study include cytoskeleton proteins and proteins that are important for the cell homeostasis, cell communication, signal transduction, stress response, as well as protein folding and trafficking (Table 1).

\subsection{Interacting partners of PrP ${ }^{\mathrm{C}}$}

Cytoskeleton associated proteins [actin, cytoplasmic 1, beta-actin-like protein 2, annexin A2, alpha-tubulin 1 and tubulin beta-5, cofilin-1, moesin, myosin-9 and vimentin]: Actin, cytoplasmic 1, and beta-actin-like protein 2 proteins are involved in cell motility, cell adhesion and reorganization of the actin cytoskeleton. PrP also plays an important role in cell adhesion [Malaga-Trillo et al. 2009]. Annexin A2 is known to contribute to the regulation of actin cytoskeleton dynamics in epithelial cell junctions [Benaud et al. 2004]. Tubulin is the major constituent of microtubules and a known interacting partner of $\operatorname{PrP}^{\mathrm{C}}$ [Nieznanski et al. 2005]. Tubulin was identified in our study as two novel isoforms, alpha-tubulin 1 and tubulin beta- 5 chain. Cofilin-1 also co-purified in our study although cofilin has been shown to be associated with the disease form of prion protein $\mathrm{PrP}^{\mathrm{Sc}}$ and to also be involved in abnormal formation of rods in the brain of Alzheimer disease patients [Giorgi et al. 2009]. Moesin, myosin-9 and vimentin have well defined roles in the maintenance of cytoskeleton assembly [Kosako et al. 1999]. These cytoskeleton associated interacting proteins are associated with $\operatorname{PrP}^{\mathrm{C}}$ during intracellular sorting and transportation [Nieznanski et al. 2005].

Proteins involved in cell communication and signal transduction [14-3-3, Laminin receptor 1, stress-induced-phosphoprotein 1, Rab7a, Arf1, annexin A1, A5 and phosphatidylinositol-4,5-bisphosphate phosphodiesterase delta-3]: 14-3-3 is a biomarker for Creutzfeldt-jacob disease (CJD) [Hsich et al. 1996] and is also known to be an interacting partner of $\mathrm{PrP}^{\mathrm{C}}$ in association with heat shock protein 60 (Hsp60) [Satoh, Onoue, Arima, and Yamamura2005]. Laminin receptor 1 or 37/67 kDa laminin receptor (identified previously as an interacting partner using the yeast two hybrid system) functions as a cell surface receptor for laminin. It plays a significant role in cell adhesion and in the consequent activation of signaling transduction [Linden et al. 2008]. Stress-induced-phosphoprotein 1 is a known interacting partner of $\mathrm{PrP}^{\mathrm{C}}$ with a suggested role in neuroprotection [Zanata et al. 2002]. Ras-related protein Rab7a, ADP- 
ribosylation factor 1, annexin A1, A5 and phosphatidylinositol-4, 5-bisphosphate phosphodiesterase delta-3 (PLC) which were identified as novel interacting partners have a suggested role in cell communication.

Protein metabolism and energy pathways [heat shock cognate $71 \mathrm{kDa}$ protein, $47 \mathrm{kDa}$ heat shock protein, stress-70 protein, glyceraldehyde 3-phosphate dehydrogenase, aspartate aminotransferase, fructose-bisphosphate aldolase $A$, glutathione S-transferase omega-1, peroxiredoxin-1]: the molecular machinery required for protein metabolism is provided by a variety of molecular chaperones that include both heat shock proteins and glucose-regulated proteins [Henle et al. 1998]. Heat shock cognate $71 \mathrm{kDa}$ protein, $47 \mathrm{kDa}$ heat shock protein and stress-70 protein (GRP75) were identified as $\mathrm{PrP}^{\mathrm{C}}$ interacting partners with possible chaperone activity. Protein disulfide isomerase which is over expressed in the brains of sporadic Creutzfeldt-Jakob disease (sCJD) patients but not other other neurodegenerative disorders (i.e. Down syndrome and Alzheimer's disease) may simply reflect a cellular defense response against the altered prion protein [Yoo et al. 2002]. Glyceraldehyde 3-phosphate dehydrogenase (GAPDH) is a known interacting partner of PrP27-30 fibrils in transmissible spongiform encephalopathies (TSEs) [Giorgi et al. 2009]. Alpha enolase, a glycolytic enzyme is upregulated in $\mathrm{PrP}^{\mathrm{C}}$ over expressing cells in response to metabolic alterations [Ramljak et al. 2008]. Aspartate aminotransferase plays a key role in amino acid metabolism and is important for metabolite exchange between mitochondria and the cytosol. It facilitates cellular uptake of long-chain free fatty acids. It is being utilized as a CSF biomarker showing central nervous system degeneration [Satoh et al. 2007]. Fructosebisphosphate aldolase $A$ is upregulated in Scrapie-infected mice and its mRNA is increased in Scrapie infection [Jang et al. 2008]. Furthermore glutathione S-transferase omega-1 is a well known detoxification enzyme that plays an important role in prostaglandin and steroid hormone synthesis [Oakley 2005]. It is involved in protection against oxidative stress and its isoform, glutathione $\mathrm{S}$-transferase $\mathrm{P}$, is reported to be up-regulated with $\mathrm{PrP}^{\mathrm{C}}$ overexpression [Ramljak et al. 2008]. Lastly, peroxiredoxin-1, which was identified as novel interacting protein, functions to protect the ribosomal machinery against damage from oxidative stress [Sideri et al. 2010].

Protein folding and nucleic acid metabolism [GrpE homolog 1 protein, peptidylprolyl cis-trans isomerase, protein SET]: GrpE homolog 1 protein is an essential 
component for the correct folding of proteins in the cell under physiological and stress conditions. It can serve as a central cellular tool for the recovery of native proteins from stress-induced aggregates. It can actively remove disease-causing toxic aggregates, such as polyglutamine-rich proteins, amyloid plaques, and prions [Ben-Zvi and Goloubinoff 2001]. Peptidyl-prolyl cis-trans isomerase also accelerates the folding of proteins and is involved in the protection of neurons against oxidative stress [Spisni et al. 2009]. Protein SET (Phosphatase 2A inhibitor, I2PP2A), an endogenous PP2A inhibitor, is a multitasking protein, involved in apoptosis; transcription; nucleosome assembly and histone binding [Liu et al. 2010].

Cell cycle and lipopolysaccharide; ATP binding proteins [elongation factor 1alpha, binding immunoglobulin protein (BiP)]: Elongation factor 1-alpha, a regulator of cytoskeleton rearrangements, is upregulated in $\operatorname{PrP}^{\mathrm{C}}$ overexpressing HEK-293 cells [Ramljak et al. 2008]. BiP binds to a mutant prion protein for an abnormally prolonged period of time and mediates mutant prion protein degradation by the proteasomal pathway. The folding of $\operatorname{PrP}$ is chaperoned by BiP and BiP plays a role in maintaining quality control in PrP maturation pathways [Jin et al. 2000].

Oxidoreductase, stress response proteins [heat shock protein (HSP) 90-alpha and beta, Lactate dehydrogenase, malate dehydrogenase, triosephate isomerase]: HSP 90-alpha and beta were up-regulated in the overexpressed $\mathrm{PrP}^{\mathrm{C}}$ conditions [Ramljak et al. 2008]. Lactate dehydrogenase is a known interacting partner of $\operatorname{PrP}^{\mathrm{C}}$ [Watts et al. 2009] and lactate dehydrogenase activity in the CSF is increased significantly in patients with Creutzfeldt-Jakob disease [Schmidt et al. 2004].

\section{2 $\operatorname{PrP}^{\mathrm{C}}$ and GTPases}

The Rab- and Arf- GTPases play a critical role in regulating the vesicle trafficking in both exo- and endocytic pathways [Bucci et al. 2000]. The importance of small GTPases in membrane trafficking is indicated by their conservation throughout eukaryotes [Nielsen et al. 2001; Nielsen et al. 2008]. Our STrEP-tag affinity purification, immunofluorescence, and reverse co-immunoprecipitation results demonstrated that Rab7a (an isoform of Rab- GTPase) and Arf1 (an isoform of Arf-GTPase) are potential interacting partners of $\operatorname{PrP}^{\mathrm{C}}$. Since the transport routes that determine $\operatorname{PrP}^{\mathrm{C}}$ endocytosis and $\mathrm{PrP}^{\mathrm{SC}}$ conversion remain elusive, this study identified an important possible Rab7a and Arf1 interaction in $\mathrm{PrP}^{\mathrm{C}}$ internalization and accumulation. 


\subsection{1 $\operatorname{PrP}^{\mathrm{C}}$ and Rab7a}

Rab7a, an important regulator of vesicular transport, is located in specific intracellular compartments (early to late endosomes) and has been shown to be involved in both the sorting and formation of transport vesicles [Vonderheit and Helenius 2005]. Rab7 is not essential for the delivery of early endosome cargo to the late endosome but plays a role in biogenesis of multivesicular bodies and their fusion to the lysosome [Vanlandingham and Ceresa 2009]. Herein, new evidence is provided for Rab7a and Arf1 dependent mechanisms in regulating $\operatorname{PrP}^{\mathrm{C}}$ trafficking in this hippocampus neuronal cell line. Intriguingly, Rab7a depletion using the siRNA knockdown system significantly increased $\mathrm{PrP}^{\mathrm{C}}$ accumulation in the cytosolic region. The localization pattern also changed to a punctuated form in contrast to the control cells. The data suggests an impairment of $\mathrm{PrP}^{\mathrm{C}}$ trafficking from early to late endosomes after knockdown of Rab7a. The immunoblot analysis in both cell lines tested (HpL3-4 transiently $\operatorname{PrP}^{\mathrm{C}}$ transfected and $\mathrm{SH}-\mathrm{SY} 5 \mathrm{Y}$ stable $\mathrm{PrP}^{\mathrm{C}}$ expressed cells) after Rab7a knockdown confirmed the increased $\operatorname{PrP}^{\mathrm{C}}$ expression. This $\operatorname{PrP}^{\mathrm{C}}$ accumulation may be attributed to the impaired biogenesis of lysosomes, which has been strongly suggested as a secondary function of Rab7a [Vanlandingham and Ceresa 2009]. Furthermore, it was demonstrated that Rab7a depletion results in $\mathrm{PrP}^{\mathrm{C}}$ accumulation and redistribution within Rab9 positive compartments. Rab9 GTPase resides in a late endosomes. The results with respect to Rab9 and prion protein showed that Rab9 overexpression in prion-infected cultured cells reduced cellular $\mathrm{PrP}^{\mathrm{Sc}}$ content [Gilch et al. 2009].

The neuropathology of most prion diseases has been accompanied by widespread deposits of amyloidal aggregates containing the misfolded prion protein $\left(\mathrm{PrP}^{\mathrm{Sc}}\right)$ [Clarke et al. 2001]. This aggregate formation has often been used as a parameter for neuronal toxicity, with characteristic resistance to proteinase $\mathrm{K}$ digestion [McKinley et al. 1983]. However, no proteinase $\mathrm{K}$ resistant $\operatorname{PrP}^{\mathrm{C}}$ was found after $48 \mathrm{H}$ in siRNA transfected transiently $\mathrm{PrP}^{\mathrm{C}}$ expressed cells (Figure 16). These data suggest that impaired Rab7a machinery leads to accumulation of $\operatorname{PrP}^{\mathrm{C}}$ but not the formation of the resistant form of $\mathrm{PrP}^{\mathrm{C}}$. 


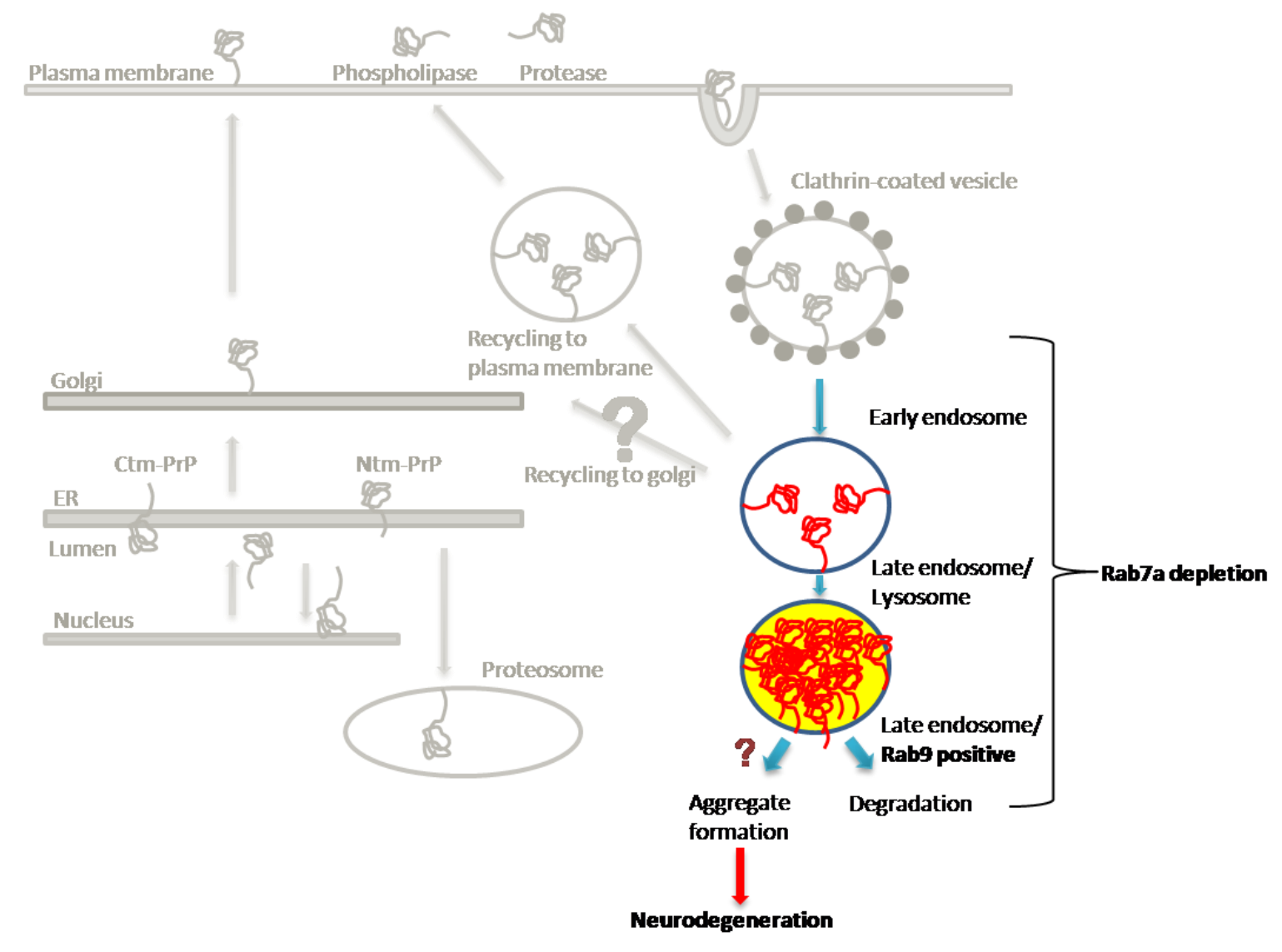

Figure 21 Influence of Rab7a depletion on $\operatorname{PrP}^{\mathrm{C}}$ expression and localization: The unique Rab7a interacting effect on $\mathrm{PrP}^{\mathrm{C}}$ expression and localization is highlighted with colors. The highlighted (colored) part shows the alteration of trafficking by the depletion of Rab7a expression which leads to the accumulation of $\mathrm{PrP}^{\mathrm{C}}$ in the Rab9 positive late endosome compartments.

\subsection{2 $\operatorname{PrP}^{\mathrm{C}}$ and Arf1}

Arfs regulate constitutive membrane trafficking and localize to early/cis-Golgi and ER-Golgi intermediate compartments. They play an important role in vesicular trafficking as an activator of phospholipase D (PLD), an enzyme involved in the regulation of secretion, endocytosis and receptor signaling [Brown et al. 1993; Fensome-Green and Cockcroft 2006]. Arfs activate PLD [Brown et al. 1993; FensomeGreen and Cockcroft 2006; Cockcroft et al. 1994] and phosphatidylinositol 4-phosphate 5-kinase (PIP5K) [Honda et al. 1999] to generate phosphatidic acid and phosphotidylinositol 4, 5-bisphosphate (PIP2) which are crucial for membrane curvature 
and membrane protein recruitment [Donaldson 2005; Donaldson 2009]. PLD directly interacts with kinases such as protein kinase $C(P K C)$ and has been shown to be involved in PrP (106-126) internalization [Paruch et al. 2006; Brandenburg et al. 2009]. Rab7a depletion was observed to increase $\operatorname{PrP}^{C}$ accumulation in early to late endosomal compartments and to significantly decrease Arf1 expression. A likely explanation would be that Rab7a knockdown may also disturb the Arf1-trans Golgi recycling complex, indicative of a possible link between Rab7a and Arf1 in $\operatorname{PrP}^{\mathrm{C}}$ trafficking.

Arfs dependent vesicle formation requires GEP (guanine nucleotide-exchange protein, an activator of Arf1) catalyzed cycling between inactive, Arf-GDP (largely cytosolic), and GTP-bound active (membrane associated) forms [Puxeddu et al. 2009]. The effect of the Arf1 interaction on $\operatorname{PrP}^{\mathrm{C}}$ localization and expression was studied by inhibiting GEP with BFA. BFA treatment resulted in a marked decline of $\operatorname{PrP}^{\mathrm{C}}$ expression. Using co-immunofluorescence techniques, it is demonstrated that BFA-Arf1 deactivation alters the sub-cellular localization and expression of $\operatorname{PrP}^{C}$. Based on the model of Arf1 function in intra-Golgi trafficking, it is proposed propose that Arf1-GTP stimulates retrograde transport of $\operatorname{PrP}^{\mathrm{C}}$ molecules within the trans-Golgi compartment toward the ER and also to the plasma membrane. The functional disruption of Arf1; however, did not influence Rab7a expression in either HpL3-4 transiently PrPC transfected or SH-SY5Y stable $\operatorname{PrP}^{\mathrm{C}}$ expressing cells.

\section{3 $\operatorname{PrP}^{\mathrm{C}}$ and alpha- tubulin 1}

The microtubular cellular structures play a central role in intracellular transport, metabolism, and cell division. Microtubule networks are used as tracks for intracellular protein trafficking. Tubulin is a major component of microtubules and is known to interact with $\operatorname{PrP}^{\mathrm{C}}$ [Dong et al. 2008; Nieznanski et al. 2005]. An interaction of alphatubulin 1 with $\operatorname{PrP}^{\mathrm{C}}$ was identified. Nocodazole treatment disrupts the microtubular network and affects the intracellular distribution of $\operatorname{PrP}^{\mathrm{C}}$ [Hachiya et al. 2004a; Hachiya et al. 2004b]. The role of nocodazole disruption of microtubules on $\operatorname{PrP}^{\mathrm{C}}$ intracellular distribution was examined. Increased $\mathrm{PrP}^{\mathrm{C}}$ expression was found in the cytosolic region after nocodazole treatment of $\operatorname{PrP}^{\mathrm{C}}$ expressing cells. Moreover, disruption of microtubules also led to the down regulation of Rab7a and Arf1 expression. Decreased Arf1 can be attributed to the Golgi membranes' kinesin-dependent dispersal following 
microtubule disruption with nocodazole [Hehnly et al. 2010]. The active transport of Rab7-containing endosomes is mediated by microtubules which fuse with other late endosomes [Vonderheit and Helenius 2005]. Disruption of microtubules could influence Rab7a expression.

Based on these results, it is interesting to speculate that $\operatorname{PrP}^{C}$ can be recycled back to the plasma membrane with a Rab7a dependent pathway and that the impaired Rab7a machinery leads to accumulation of $\operatorname{PrP}^{\mathrm{C}}$ but not to the formation of the resistant form of $\operatorname{PrP}^{\mathrm{C}}$. It remains to be determined whether this Rab7a dependent $\operatorname{PrP}^{\mathrm{C}}$ accumulation in the Rab9 positive endosomal compartments is crucial for the conversion of $\mathrm{PrP}^{\mathrm{C}}$ to $\mathrm{PrP}^{\mathrm{Sc}}$. The results also suggest that Arf1-GTP stimulates retrograde transport of $\mathrm{PrP}^{\mathrm{C}}$ molecules within the trans-Golgi compartment toward the $\mathrm{ER}$ and also to the plasma membrane. The functional disruption of Arf1; however, did not influence Rab7a expression. Moreover, disruption of microtubules also led to the down regulation of Rab7a and Arf1 expression.

In conclusion, these studies identified a large number of both known and previously unknown $\mathrm{PrP}^{\mathrm{C}}$ interacting proteins. It remains to be demonstrated whether direct interactions take place or not as well as exactly what the actual interaction sites of these proteins have with $\operatorname{PrP}^{\mathrm{C}}$. However, these results further highlight the pivotal role of endosomal compartments in $\operatorname{PrP}^{\mathrm{C}}$ trafficking and could help to explain the physiological role of $\mathrm{PrP}^{\mathrm{C}}$ and their associations with these interacting proteins. 


\section{Appendix A}

- pENTRY-IBA1-Cloning site

T T TACACAGGAAACA GCTAT GACCATGATTACGCCAAGCTCGAAA T AACCCTCACTAAAGGGAACAAAAGCTGGAGC TCCACCGCGGT ENTRY-Primer-for

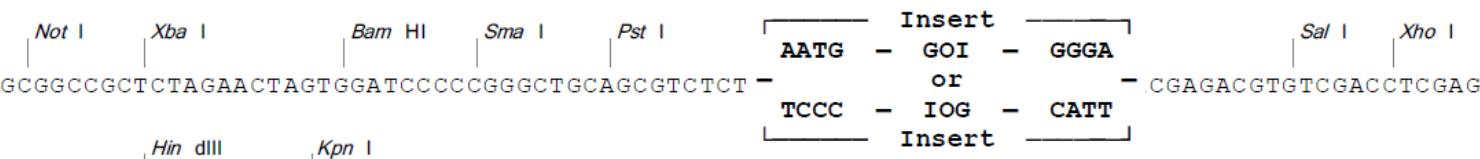

$\mathrm{GOI}=$ Gene of interest

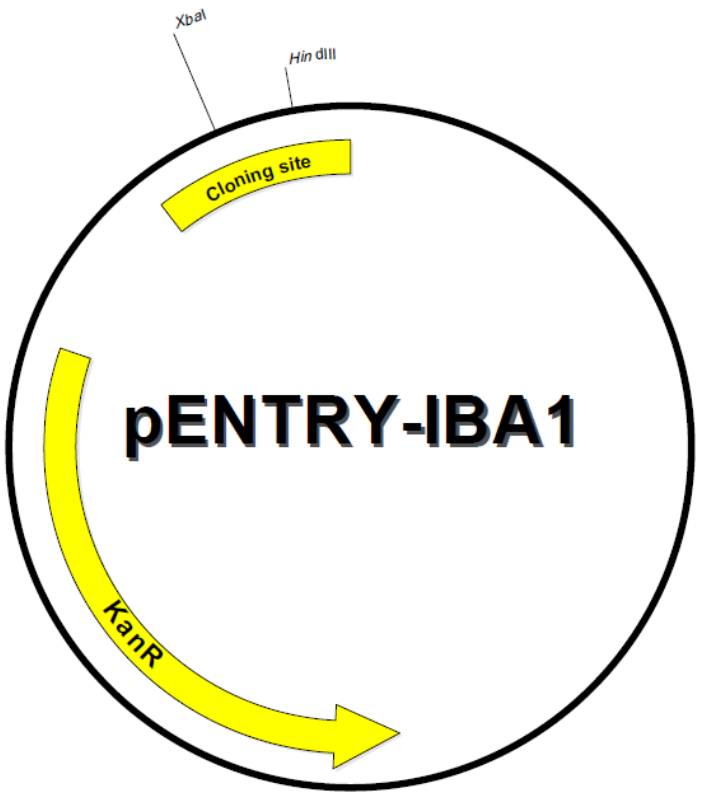

\begin{tabular}{|c|c|c|c|}
\hline Features & from bp & to $b p$ & Sequencing primer \\
\hline Kanamycin resistance gene & 1143 & 1937 & \multirow{3}{*}{$\begin{array}{l}\text { ENTRY-Primer-for } \\
\text { 5'- GACCATGATTACGCCAAGCTCG - -3' }\end{array}$} \\
\hline forward primer binding site & 2182 & 2203 & \\
\hline \multirow[t]{3}{*}{ reverse primer binding site } & $2370^{*}$ & $2392^{*}$ & \\
\hline & & & \multirow{3}{*}{$\begin{array}{l}\text { ENTRY-Primer-rev } \\
5^{\prime}-\text { CGTTGTAAAACGACGGCCAGTG -3' }\end{array}$} \\
\hline & & & \\
\hline total vector length & & 2392* & \\
\hline
\end{tabular}




\section{- pESG-IBA103-Cloning site}

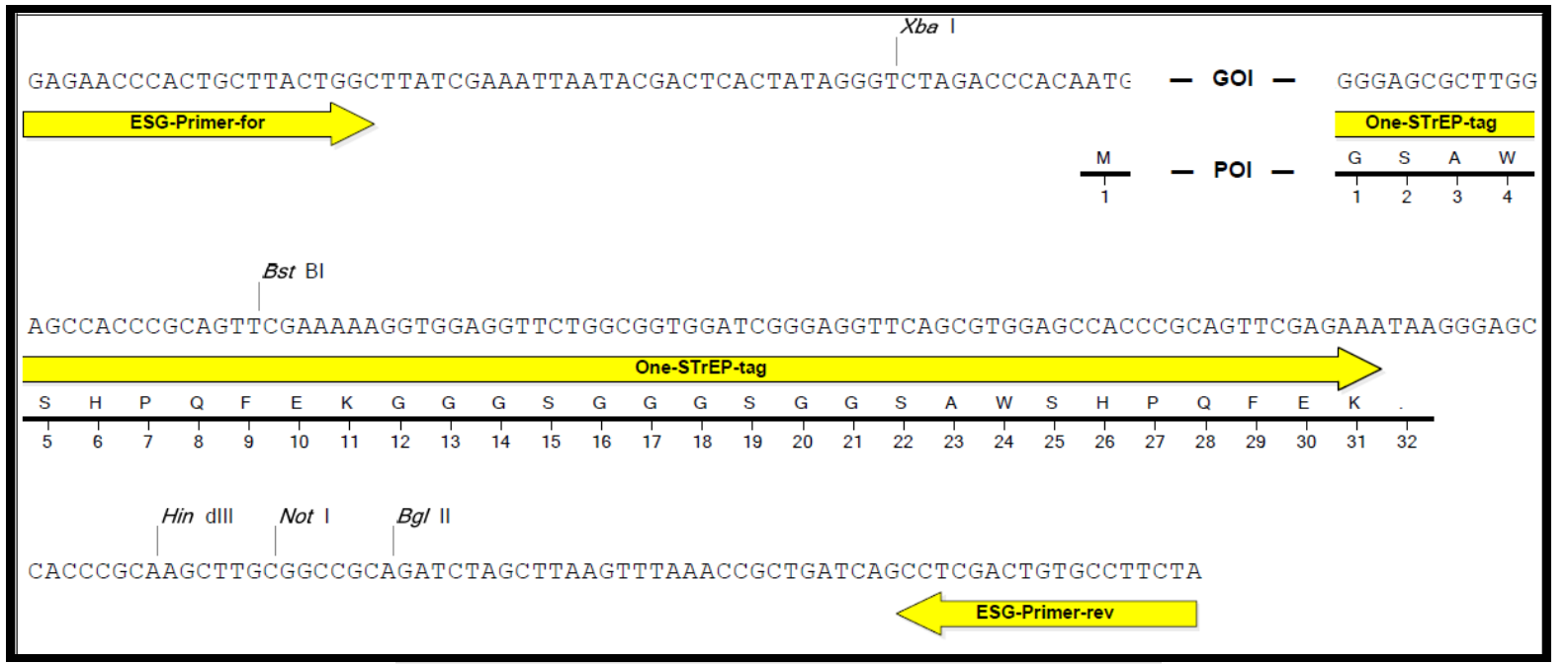

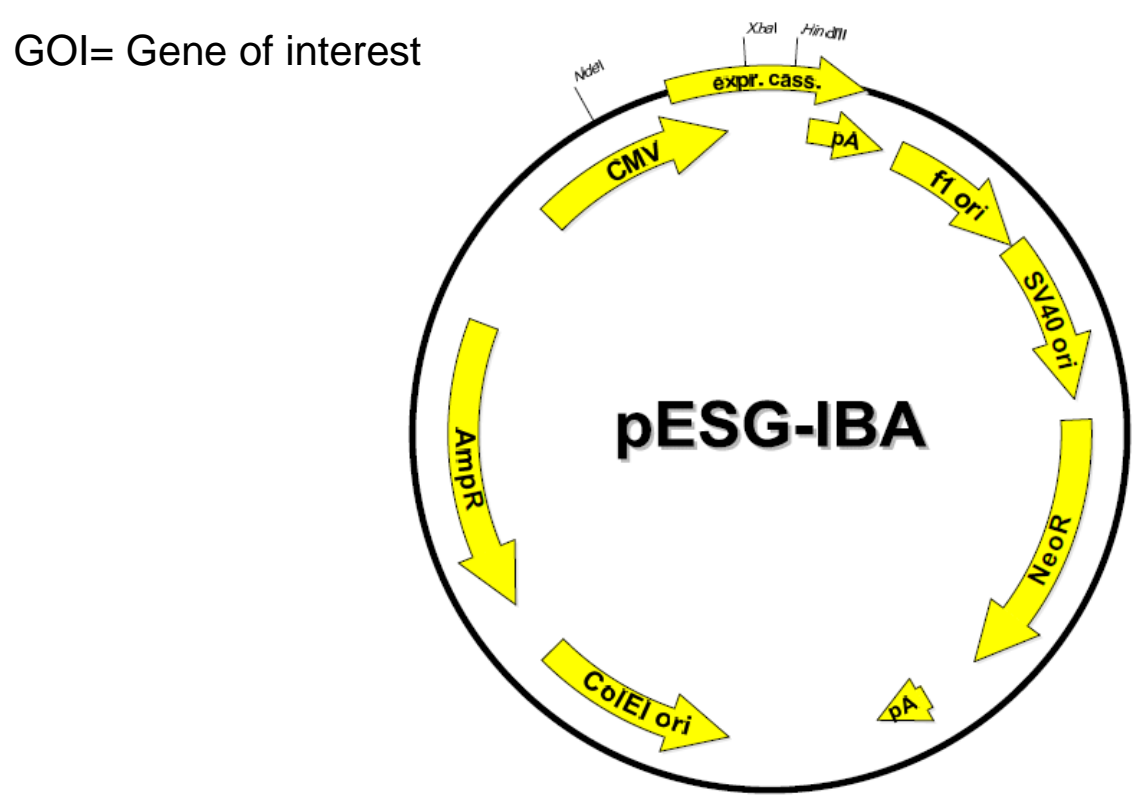

\begin{tabular}{|c|c|c|c|}
\hline Features & from bp & to bp & Sequencing primer \\
\hline fl origin & 259 & 687 & \multirow{11}{*}{$\begin{array}{l}\text { ESG-Primer-for (Cat. No. 5-0000-121) } \\
\text { 5'- GAGAACCCACTGCTTACTGGC -3' }\end{array}$} \\
\hline SV40 ori & 692 & 1035 & \\
\hline Neomycin resistance gene & 1097 & 1891 & \\
\hline ColEl ori & 2637 & 3222 & \\
\hline Ampicillin resistance gene & 3393 & 4253 & \\
\hline CMV promoter & 4621 & 5208 & \\
\hline forward primer binding site & 5221 & 5241 & \\
\hline One-STrEP-tag & $5287^{*}$ & $5379 *$ & \\
\hline reverse primer binding site & $5441^{*}$ & $5458^{*}$ & \\
\hline polyA signal sequence & 1 & 213 & \\
\hline total vector length & & 5458* & \\
\hline
\end{tabular}




\section{Appendix B}

Peptides sequence of identified proteins.

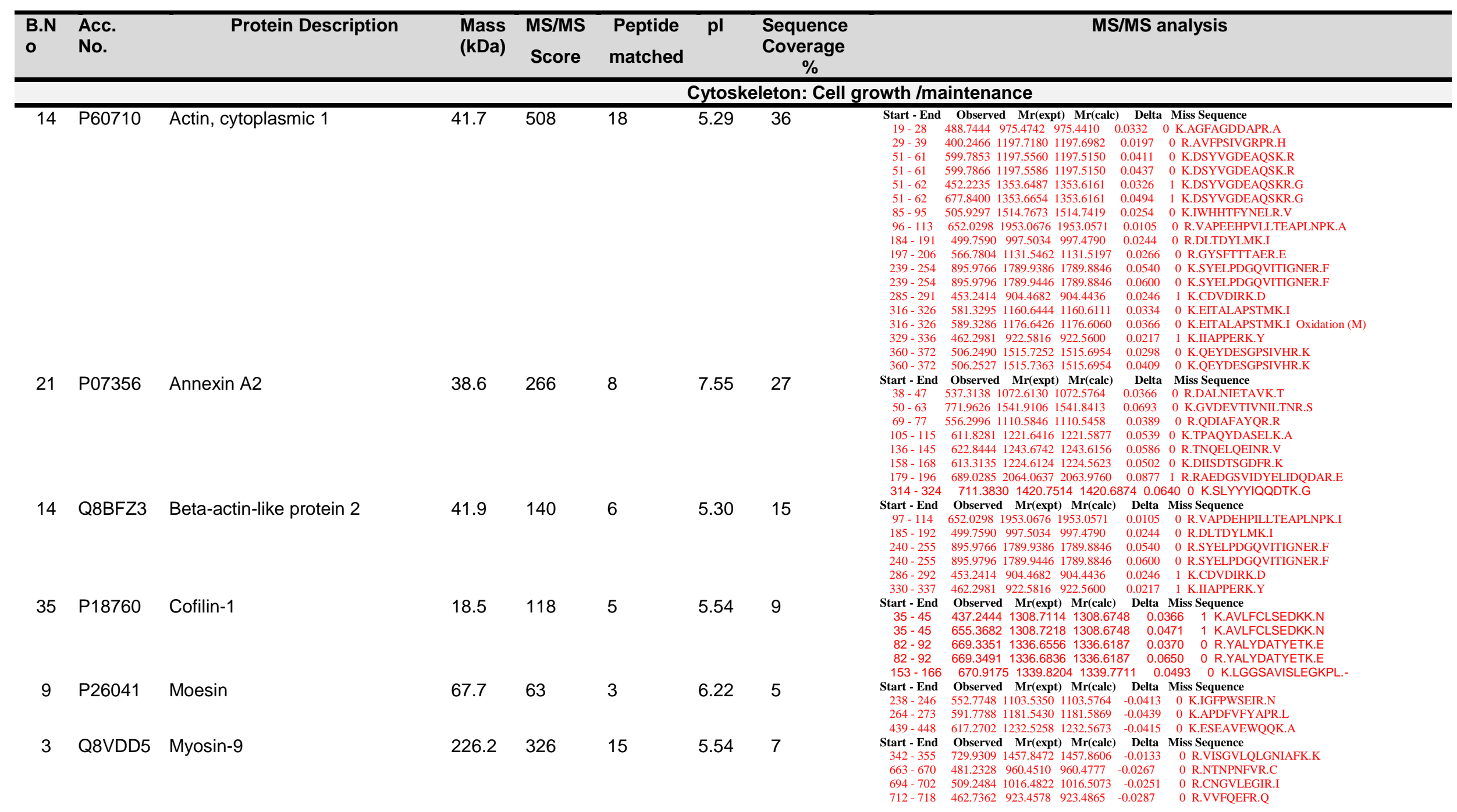


33 Q9WVA4 Transgelin-2

12 P68369 Tubulin alpha-1A

13 P99024 Tubulin beta-5 chain

12 P20152 Vimentin
22.3

12

50.1

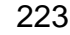

9

4.94

28

49.6

193

4.78

19 $\begin{array}{lllllll}719-731 & 520.2798 & 1557.8176 & 1557.8515 & -0.0339 & 1 & \text { R.QRYEILTPNSIPK.G }\end{array}$ $\begin{array}{llllll}746-755 & 597.2985 & 1192.5824 & 1192.6088 & -0.0263 & \text { 0 K.ALELDSNLYR.I } \\ 765-775 & 4085372 & 12225898 & 1222.6306 & -0.0408 & \text { 0 R.AGVLAHLEEER.D }\end{array}$

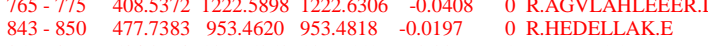

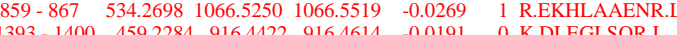

$1418-1433650.65641948 .94741948 .9854 \quad-0.0380 \quad$ 0 R.LQQELDDLLVDLDHQR.Q

1434 - $1441452.7284903 .4422903 .4661 \quad-0.0239 \quad$ 0 R.QSVSNLEK.K

$1445-1454 \quad 610.81881219 .62301219 .6448-0.0218 \quad 1$ K.KFDQLLAEEK.T

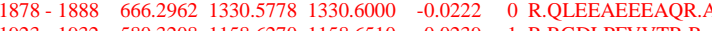

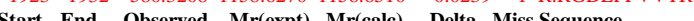

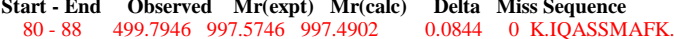

$\begin{array}{llllll}128-139 & 6163934 & 12307722 & 12306754 & 0.0968 & 0\end{array}$

$\begin{array}{lllllll}161-171 & 640.3479 & 1278.6812 & 1278.5840 & 0.0972 & \text { O R.NFSDNQLOEGK.N }\end{array}$

$\begin{array}{lllllll}172 & -182 & 609.8646 & 1217.7146 & 1217.6187 & 0.0960 & 0 \\ 0 & \text { K.NVIGLQMGTNR.G }\end{array}$

Start - End Observed Mr(expt) Mr(calc) Delta Miss Sequence

NTFFSETGAGK.H

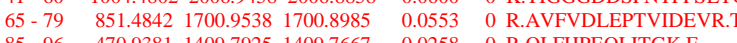

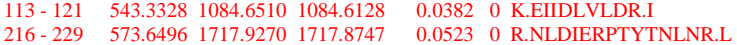

$265-280 \quad 586.3396 \quad 1755.99701755 .9559 \quad 0.0410 \quad 0$ R.IHFPLATYAPVISAEK.A

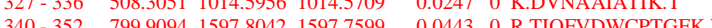

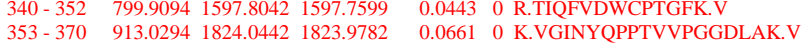

Start - End Observed Mr(expt) Mr(calc) Delta Miss Sequence

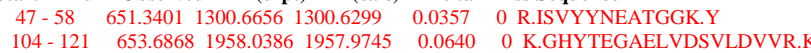

$242-251 \quad 565.8151 \quad 1129.6156 \quad 1129.5880 \quad 0.0277 \quad 0$ R.FPGQLNADLR.K

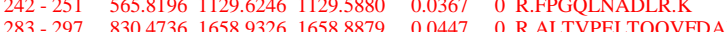

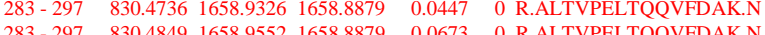

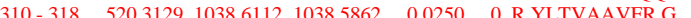

$351-359 \quad 514.7861 \quad 1027.5576 \quad 1027.5121 \quad 0.0456 \quad$ 0 K.TAVCDIPPR.G

$\begin{array}{cccccc}\text { Start - End } & \text { Observed } & \text { Mr(expt) } & \text { Mr(calc) } & \text { Delta Miss Sequence } \\ 37-50 & 499.2907 & 1494.8503 & 1494.7790 & 0.0712 & 0\end{array}$

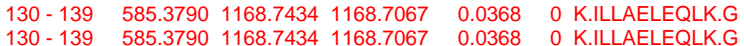

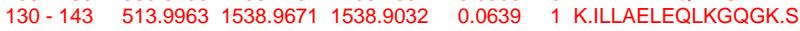

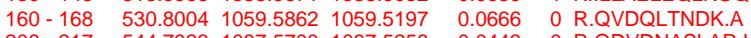

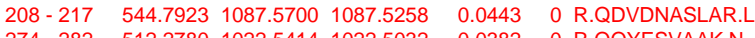

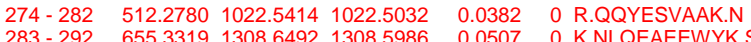

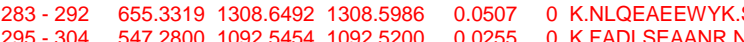

Cell communication : Signal transduction

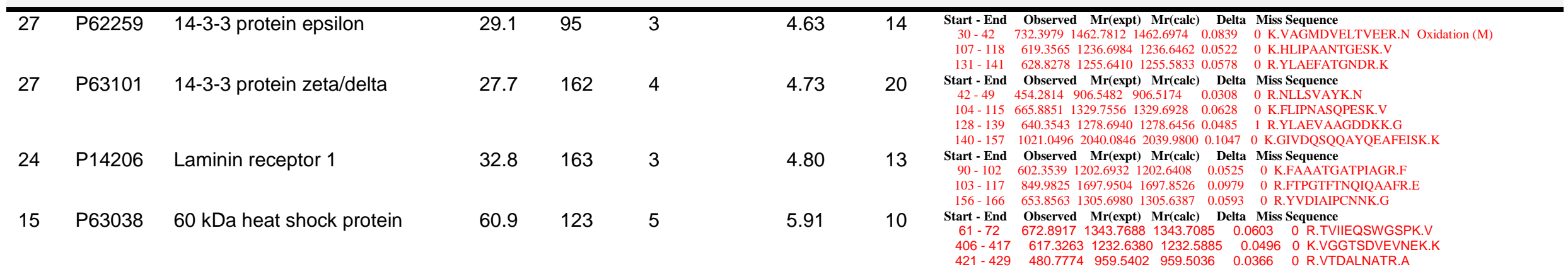




\section{Appendix}

21 P10107 Annexin A1

22

48036 Annexin A5

Q60864 Stress-induced-phosphoprotein 162.5

253

6.40

6.40

32 P51150 Ras-related protein Rab-7a

$23.4 \quad 93$

8

6.97

4.74
$20.6-57 \quad 3$
22

430 - $446 \quad 842.9941 \quad 1683.9736 \quad 1683.8978 \quad 0.0759 \quad$ O R.AAVEEGIVLGGGCALLRC

10 Start - End Observed Mr(expt) Mr(calc) Delta Miss Sequence

$544.35361086 .69261086 .6107 \quad 0.0819 \quad 0 \quad$ R.MVGLDAAGK

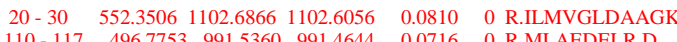

Start - End Observed Mr(expt) Mr(calc) Delta Miss Sequence

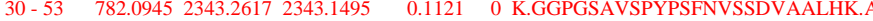

$\begin{array}{llllll}114-124 & 631.8317 & 1261.6488 & 1261.5939 & 0.0550 & 0 \\ 167-178 & \text { K.TPAQFDADELR.G }\end{array}$

$\begin{array}{lllllll}167-178 & 447.8936 & 1340.6590 & 1340.6208 & 0.0381 & \text { 1 K.DITSDTSGDFRK.A }\end{array}$

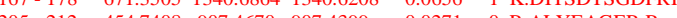

$\begin{array}{llllllll}205-212 & 454.746 & 907.46746 & 907.4399 & 0.0274 & \text { O R.ALYEAGER.R } \\ 200747 & \text { O R ALYEAGER R }\end{array}$

$214-228 \quad 551.32351650 .948716508941 \quad 0.0546 \quad$ 1 R.KGTDVNVFTTILTSR S

$\begin{array}{llllll}215-228 & 762.4437 & 1522.8728 & 1522.7991 & 0.0737 & 0 \\ 2 & \text { K.GTDVNVFTTILTSR.S }\end{array}$

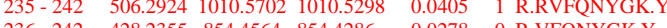

$\begin{array}{llllll}236-242 & 428.2355 & 854.4564 & 854.4286 & 0.0278 & \text { 0 R.VFQNYGK.Y }\end{array}$

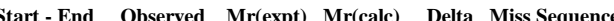

$\begin{array}{lllll}634.8223 & 1267.6300 & 1267.5834 & 0.0467 & 0 \\ 0\end{array}$

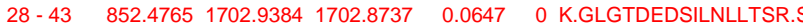

$\begin{array}{lllllll}49-56 & 496.7637 & 991.5128 & 991.4974 & 0.0154 & 0 & \text { R.QEIAQEFK.T }\end{array}$

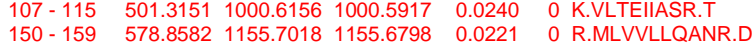

$\begin{array}{llllll}150-159 & 578.8582 & 1155.7018 & 1155.6798 & 0.0221 & \text { 0 R.MLVVLLQANR.D } \\ 192-199 & 477.7874 & 953.5602 & 953.5335 & 0.0268 & 0 \\ 2 & \text { K.FITIFGTR.S ) }\end{array}$

$\begin{array}{lllllll}192-199 & 477.7874 & 953.5602 & 953.5335 & 0.0221 & 0 & \text { K. } \\ 275-283 & 553.8145 & 1105.6144 & 1105.5768 & 0.0377 & 0 & \text { R.SEIDLFNIR.K }\end{array}$

Start - End Observed Mr(expt) Mr(calc) Delta Miss Sequence

0.1070 K.ALSAGNDDALQCYSEAIK.L

$110-118 \quad 532.26651062 .51841062 .4764 \quad 0.0421 \quad$ 0 K.EGLQNMEAR.L

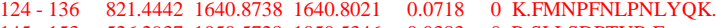

$\begin{array}{llllllll}145 & -153 & 526.2937 & 1040.5728 & 1650.5346 & 0.0783 & 0 & \text { K. R.SLLSDPTYR.E }\end{array}$

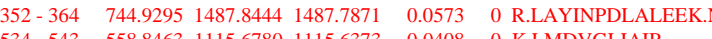

Start-End Observed Mreept) Mr(calc) Delta Miss Sequence

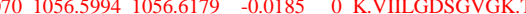

$39-48 \quad 518.7822 \quad 1035.5498 \quad 1035.5601 \quad-0.0102 \quad$ 0 K.ATIGADFLTK.E

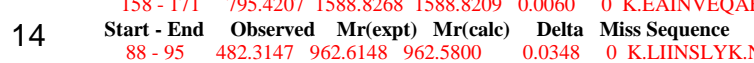

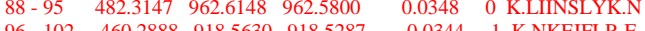

$\begin{array}{lllllll}103-114 & 638.3587 & 1274.7028 & 1274.6354 & 0.0675 & 0 & \text { R.ELISNASDALDK }\end{array}$

103-116 $515.63311543 .87751543 .8205 \quad 0.0569 \quad$ 1 R.ELISNASDALDKIR.L

$\begin{array}{llllll}143-156 & 510.6133 & 1528.8181 & 1528.7668 & 0.0513 & 0 \\ 385 & \text { K.NLLHVTDTGVGMTR.E }\end{array}$

$\begin{array}{llllll}385-395 & 594.3685 & 1186.7224 & 1186.6710 & 0.0514 & 0 \\ 396 & \text { O K.SILFVPTSAPR.G }\end{array}$

$\begin{array}{llllll}396-405 & 572.3105 & 1142.6064 & 1142.5608 & 0.0457 & \text { 1 R.GLFDEYGSKK.S } \\ 435-448 & 743.4206 & 1484.8266 & 1484.7471 & 0.0795 & 0 \\ 0\end{array}$

$\begin{array}{lllllllll}494-503 & 570.3190 & 1138.6234 & 1138.5731 & 0.0504 & \text { 0 K.LGVIEDHSNR.T }\end{array}$

$\begin{array}{llllll}4972-682 & 645.3359 & 1288.6572 & 1288.5935 & 0.0637 & 0 \\ 6 & \text { K.DISTNYYASQK.K }\end{array}$

$\begin{array}{lllllll}683-690 & 502.7988 & 1003.5830 & 1003.5451 & 0.0380 & 1 & \text { K. KTFEINPR.H } \\ 684-690 & 438.7529 & 875.4912 & 875.4501 & 0.0411 & 0 & \text { KTFEINPR. H }\end{array}$

Metabolism: Energy pathways

$16 \quad \mathrm{P} 17182 \quad$ Alpha-enolase

16
P05202 Aspartate aminotransferase,

mitochondria $\begin{array}{lll}47.3 & 220 & 7\end{array}$

9.13

15

Start - End Observed Mr(expt) Mr(calc) Delta Miss Sequence

O.AAVSGASTGIYEALELR.D

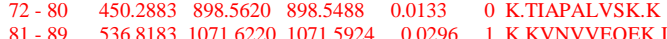

$\begin{array}{lllllll}270-281 & 7203997 & 1438 & 7848 & 14387344 & 0.0505 & 0\end{array}$

$344-358 \quad 817.4485 \quad 1632.8824 \quad 1632.8141 \quad 0.0683 \quad 0$ K.VNOIGSVTESLQACK.L

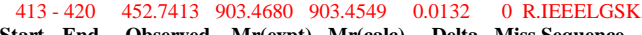

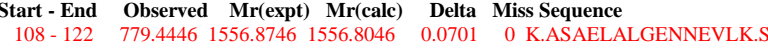

$\begin{array}{llllll}108-122 & 779.4446 & 1556.8746 & 1556.8046 & 0.0701 & \text { 0 K.ASAELALGENNEVLK S } \\ 126-139 & 725.4400 & 1448.8654 & 1448.7988 & 0.0667 & 0\end{array}$

$\begin{array}{llllll}140-147 & 439.2592 & 876.5038 & 876.4818 & 0.0221 & \text { 0 R.VGASFLQR.F } \\ 288-296 & 490.7846 & 979.5546 & 979.5161 & 0.0385 & \text { 0 R.VGAFTVVCK.D }\end{array}$

$\begin{array}{llllll}326-337 & 635.8948 & 1269.7750 & 1269.7292 & 0.0458 & \text { O R.IAATILTSPDLR.K } \\ 326-338 & 466.9622 & 1397.8648 & 1397.8242 & 0.0406 & \text { 1 R.IAATILTSPDLRK.Q }\end{array}$ 
$\begin{array}{llllll}356-364 & 515.8410 & 1029.6674 & 1029.6182 & 0.0492 & 1\end{array}$

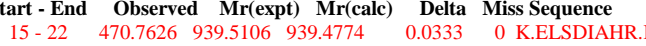

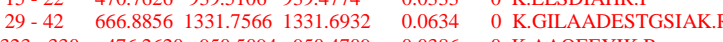

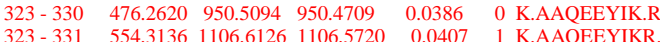
$\begin{array}{llllll}323-331 & 554.3142 & 106.6138 & 1106.5720 & 0.0419 & \text { I K.AAQEEYIKR.A } \\ 332-342 & 566.8150 & 1131.6154 & 1131.5706 & 0.0448 & 0\end{array}$

$117-137749.06702244 .1792 \quad 2244.09190 .0873 \quad 0$ R.VIISAPSADAPMFVMGVNHEK.Y

$144-160910.48221818 .9498 \quad 1818.89680 .05310$ K.IVSNASCTTNCLAPLAK.V

$\begin{array}{llllll}199-213 & 685.3871 & 1368.7596 & 1368.7361 & 0.0235 & \text { 0 R.GAAQNIIPASTGAAK.A }\end{array}$

$\begin{array}{llllll}218-225 & 435.2640 & 868.5134 & 868.5018 & 0.0116 & 0 \\ 22 & \text { K.VIPELNGK. }\end{array}$

$\begin{array}{cccccc}226-232 & 406.2172 & 810.4198 & 810.4058 & 0.0140 & \text { 0 K.LTGMAFR.V } \\ 233-246 & 778.9298 & 1555.8450 & 1555.8029 & 0.0422 & \text { 0 R.VPTPNVSVVDLTCR.L }\end{array}$

$\begin{array}{llllll}322-332 & 630.3224 & 1258.6302 & 1258.5937 & 0.0365 & 0 \\ 0 & \text { R.VVDLMAYMASK.E }\end{array}$

$\begin{array}{lllllll}322-332 & 630.3232 & 1258.6318 & 1258.5937 & 0.0381 & \text { O R.V VDLMAYMASK.E }\end{array}$

Start - End Observed Mr(expt) Mr(calc) Delta Miss Sequence

De

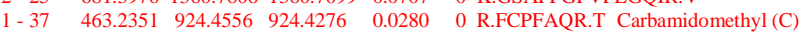

$\begin{array}{llllll}49-57 & 540.3301 & 1078.6456 & 1078.6135 & 0.0322 & 0 \\ 123 & \text { O.HEVININLK.N }\end{array}$

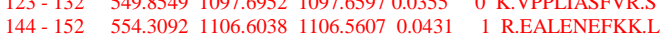

Start - End Observed Mr(expt) Mr(calc) Delta Miss SeYNEFK

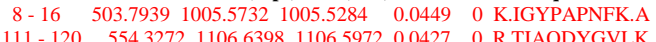

111 - $128 \quad 661.70981982 .10761982 .01090 .0967 \quad$ 1 R.TIAQDYGVLKADEGISFR.G

$\begin{array}{lllllll}129-136 & 460.7717 & 919.5288 & 919.5015 & 0.0274 & 0 & \text { R.GLFIIDDK.G } \\ 129 & 140 & 453.9479 & 1358.8219 & 13587922 & 0.0297 & 1\end{array}$

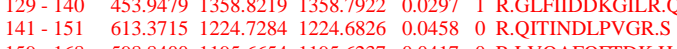

\section{Protein metabolism}

\begin{tabular}{lll}
\hline 6 & P58252 & Elongation factor 2
\end{tabular}

P63017

Heat shock cognate $71 \mathrm{kDa}$ protein 70.8

236

13

12

P09103 Protein disulfide-isomerase

95.2124

5

Protein disulfide-isomerase A3

56.
5.37

6.41

4.79

5.88
Start - End Observed Mr(expt) Mr(calc) Delta Miss Sequence

$240-249 \quad 509.27321016 .5318 \quad 1016.4887 \quad 0.0432 \quad$ 0 K.GEGQLSAAER A $265-272 \quad 456.2335 \quad 910.4524 \quad 910.4185 \quad 0.0340 \quad 0$ R.YFDPANGK.F

$\begin{array}{llllll}416-426 & 547.3389 & 1092.6632 & 1092.6179 & 0.0453 & \text { 0 R.VFSGVVSTGLK. } \\ 573-580 & 461.7394 & 921.4642 & 921.4556 & 0.0087 & 0 \text { K SPPVVSYRE. }\end{array}$

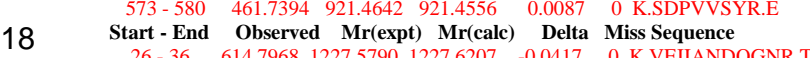

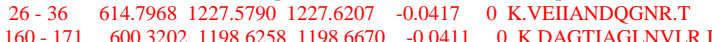

$221-236564.55341690 .6384 \quad 1690.7183 \quad-0.0800 \quad$ 0 K.STAGDTHLGGEDFDNR.M

$\begin{array}{lllllll}237-246 & 618.2911 & 1234.5676 & 1234.6169 & -0.0492 & \text { O R.MVNHFIAEFK.R } \\ 300-311 & 494.2325 & 14796757 & 14797470 & -0.0713 & \text { 1 R.ARFEELNADLFR. }\end{array}$

$\begin{array}{lllllll}300-311 & 494.2325 & 1479.6757 & 1479.7470 & -0.0713 & 1 & \text { R.ARFEELNADLFR.G } \\ 302-311 & 627.2891 & 12525636 & 1252.6088 & -0.0451 & \text { O R.FEELNADLFR.G }\end{array}$

$\begin{array}{llllll}302-311 & 627.2891 & 1252.5636 & 1252.6088 & -0.0451 & \text { 0 R.FEELNADLFR.G } \\ 312-319 & 429.7122 & 857.4098 & 857.4494 & -0.0396 & \text { O R.GTLDPVEK. }\end{array}$

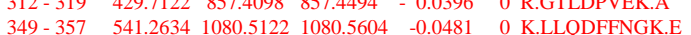

$\begin{array}{lllllll}3416-423 & 465.7547 & 929.4948 & 929.5294 & -0.0346 & 1 \text { K RNTTPTK } Q\end{array}$

$501-509 \quad 50926371016.51281016 .5614 \quad-0.0486 \quad 1$ K.ITITNDKGR.L

\begin{tabular}{llllll}
$510-517$ & 495.2458 & 988.4770 & 988.5189 & -0.0418 & 1 \\
\hline & R.LSKEDIER.M
\end{tabular}

$\begin{array}{lllllll}540-550 & 660.2779 & 1318.5412 & 1318.5863 & -0.0451 & 0 & \text { K.NSLESYAFNMK.A }\end{array}$

$\begin{array}{llllll}574-583 & 639.2913 & 1276.5680 & 1276.6122 & -0.0441 & 0 \\ 602-609 & 4727433 & 943.4720 & 9435161 & 0.0 N E I I S W L D K . N\end{array}$

Start - 602 Ond Obsed M.

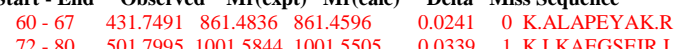

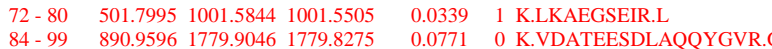

$\begin{array}{crrrrr}84-99 & 890.9596 & 1779.9046 & 1779.8275 & 0.0771 & \text { 0 K.VDATEESDLAQQYG } \\ 329-340 & 470.5771 & 1408.7095 & 1408.6722 & 0.0373 & \text { 0 K.YKPESDELTAEK.I }\end{array}$

$\begin{array}{llllll}341-347 & 481.7499 & 961.4852 & 961.4440 & 0.0413 & 0 \\ 4 . I T E F C H R . F\end{array}$

$427-438 \quad 655.32911308 .6436 \quad 1308.5867 \quad 0.0569 \quad$ O K.MDSTANEVEAVK.

Start - End Observed Mr(expt) Mr(calc) Delta Miss Sequence

$\begin{array}{lrrrrr}63-73 & 596.3225 & 1190.6304 & 1190.5931 & 0.0373 & \text { 0 R.LAPEYEAAATR.L } \\ 131-140 & 498.3008 & 994.5870 & 994.5560 & 0.0311 & \text { 0 K.QAGPASVPLR.T }\end{array}$ 
P19324 Serpin H1 (47 kDa heat shock

protein)

10 P38647 Stress-70 protein, mitochondrial
$46.5 \quad 120 \quad 3$

$73.4 \quad 397 \quad 9$
$259-271 \quad 804.41521606 .8158 \quad 1606.7403 \quad 0.0756 \quad 0$ K.DLLTAYYDVDYEK.N $\begin{array}{llllll}297-304 & 439.2591 & 876.5036 & 876.4817 & 0.0219 & 0 \\ 0 & \text { K.LNFAVASR.K }\end{array}$

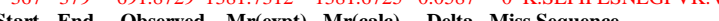

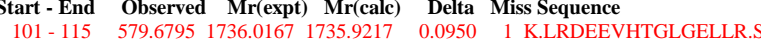

$\begin{array}{llllll}308-318 & 612.8617 & 1223.7088 & 1223.6510 & 0.0578 & \text { 0 K.GVVEVTHDLQK.H }\end{array}$

$\begin{array}{llllllll}393-404 & 653.8762 & 1305.7378 & 1305.6677 & 0.0701 & 0 & \text { R.DNQSGSLLFIGR.L }\end{array}$

Start - End Observed Mr(expt) Mr(calc) Delta Miss Sequence

$\begin{array}{llllll}77-85 & 479.7308 & 957.4470 & 957.4879 & -0.0409 & \text { 0 K.VLENAEGAR.T } \\ 160-173 & 777.4011 & 1552.7876 & 15528323 & -0.0447 & \text { 0 K.LYSPSOIGAFVLMK.M }\end{array}$

$\begin{array}{llllll}1607-218 & 621.8179 & 1241.6212 & 1241.6728 & -0.0515 & \text { 0 K.DAGOISGLNVLR.V }\end{array}$

$\begin{array}{llllllll}349-360 & 667.3468 & 1332.6790 & 1332.7289 & -0.0499 & 0 & \text { R.AQFEGIVTDLIK.R }\end{array}$

$\begin{array}{lllllll}349-361 & 497.2584 & 1488.7534 & 1488.8300 & -0.0766 & 1 & \text { R.AQFEGIVTDLIKR.T }\end{array}$

$\begin{array}{llllllll}378-391 & 723.8605 & 1445.7064 & 1445.7548 & -0.0484 & 0 & \text { K.SDIGEVILVGGMTR.M }\end{array}$

$\begin{array}{lllllll}626-634 & 540.7139 & 1019.4132 & 1019.4520 & -0.0387 & 0 & 0\end{array}$

Regulation of nucleic acid metabolism

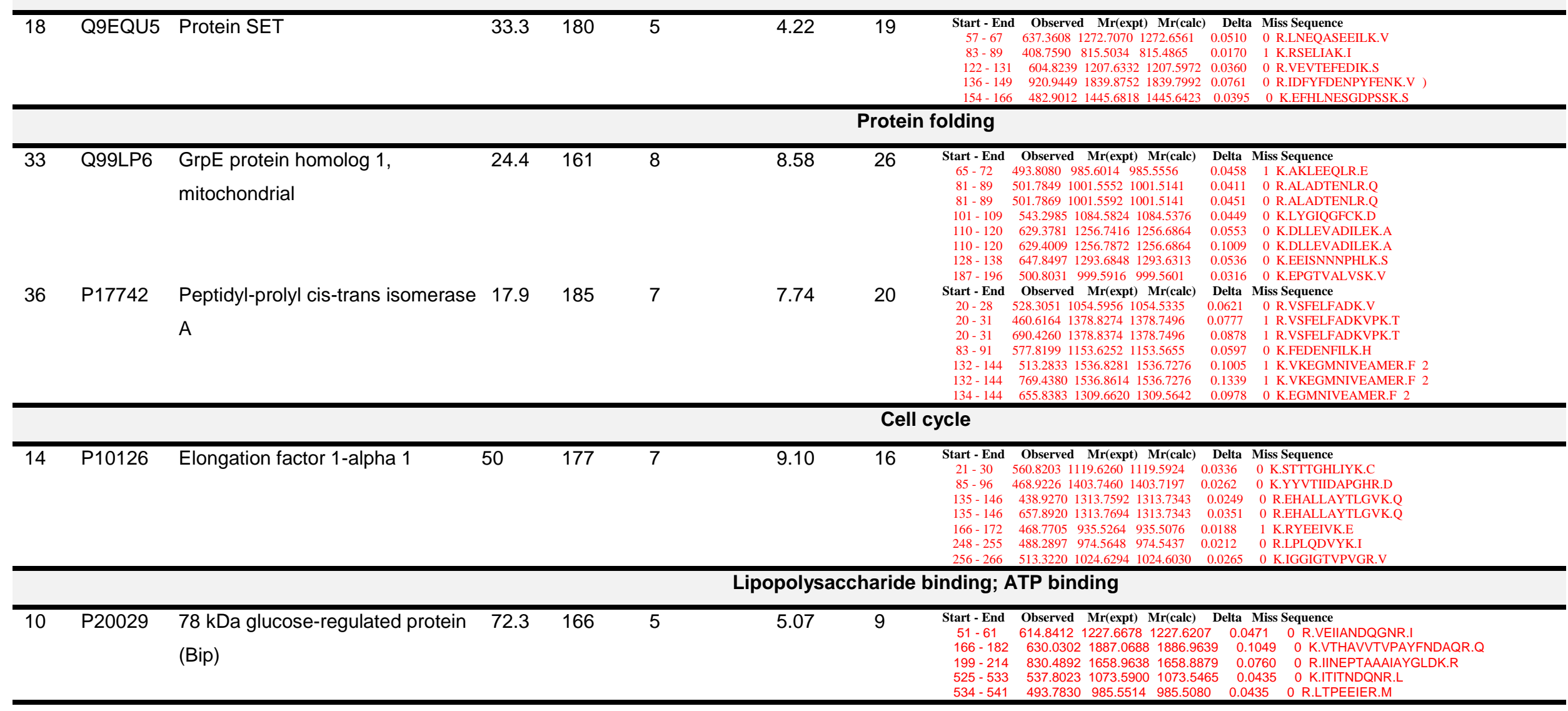




\begin{tabular}{|c|c|c|c|c|c|c|c|c|c|c|c|c|c|}
\hline 13 & Q61753 & $\begin{array}{l}\text { D-3-phosphoglycerate } \\
\text { dehydrogenase }\end{array}$ & 56.5 & 252 & 8 & 6.12 & 16 & $\begin{array}{c}\text { Start - End } \\
9-20 \\
22-33 \\
59-69 \\
147-155 \\
237-247 \\
352-364 \\
385-394 \\
462-469\end{array}$ & $\begin{array}{l}\text { Observed } \\
717.867914 \\
649.892011 \\
565.823911 \\
450.2976 \\
550.3247 \\
666.4022 \\
536.3125 \\
465.2950\end{array}$ & $\begin{array}{rl}\text { Mr(expt) } \\
433.721214 \\
297.769412 \\
1729.633211 \\
898.58068 \\
1098.6348 & 1 \\
1930.7898 & 1 \\
1070.6104 \quad 1 \\
928.5754\end{array}$ & $\begin{array}{l}\text { Mr(calc) } \\
433.6643 \\
2127.7242 \\
1129.5979 \\
898.5600 \\
1098.6033 \\
1330.7457 \\
1070.5720 \\
928.5494\end{array}$ & $\begin{array}{r}\text { Delta } \\
0.0570 \\
0.0433 \\
0.0354 \\
0.0207 \\
0.0315 \\
0.0442 \\
0.0384 \\
0.0260\end{array}$ & $\begin{array}{l}\text { Miss Sequence } \\
0 \text { K.VLISDSLDPCCR.K } 2 \\
0 \text { K.ILQDGGLQVVEK.Q } \\
\text { 0 K.VTADVINAAEK.L } \\
\text { 0 K.TLGILGLGR.I } \\
0 \text { R.GGIVDEGALLR.A } \\
0 \text { K.GTIQVVTQGTSLK.N } \\
\text { 0 K.QADVNLVNAK.L } \\
0 \text { R.GQPLVFR.A. }\end{array}$ \\
\hline \multirow[t]{11}{*}{9} & P07901 & Heat shock protein HSP 90-alpha & 84.7 & 325 & 13 & 4.93 & 15 & Start - End & Observed & Mr(expt) & Mr(calc) & Delta & Miss Sequence \\
\hline & & & & & & & & $\begin{array}{l}88-100 \\
88-100\end{array}$ & $\begin{array}{l}675.34401 \\
683.33951\end{array}$ & 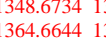 & $\begin{array}{l}1348.7272 \\
1364.7221\end{array}$ & $\begin{array}{l}-0.0538 \\
-0.0577\end{array}$ & $\begin{array}{l}\text { 0 R.TLTIVDTGIGMTK.A } \\
0 \text { R.TLTIVDTGIGMTK.A }\end{array}$ \\
\hline & & & & & & & & $174-182$ & 482.1929 & 962.37129 & 962.4127 & -0.0415 & 0 R.TDTGEPMGR.G \\
\hline & & & & & & & & $\begin{array}{l}186-201 \\
210-224\end{array}$ & $\begin{array}{l}672.3232 \\
593.6246\end{array}$ & $\begin{array}{l}2013.94782 \\
1777.85201\end{array}$ & $\begin{array}{l}2014.0371 \\
1777.9403\end{array}$ & $\begin{array}{l}-0.0893 \\
-0.0883\end{array}$ & $\begin{array}{l}1 \text { K.VILHLKEDQTEYLEER.R } \\
0 \text { K.HSQFIGYPITLFVEK.E }\end{array}$ \\
\hline & & & & & & & & $285-293$ & 576.2495 & $1150.4844 \quad 1$ & 1150.5506 & -0.0661 & 0 K.YIDQEELNK.T \\
\hline & & & & & & & & $285-293$ & 576.2576 & 1150.50061 & 1150.5506 & -0.0499 & 0 K.YIDQEELNK.T \\
\hline & & & & & & & & $294-300$ & 451.2433 & 900.47209 & 900.5181 & -0.0461 & 0 K.TKPIWTR.N \\
\hline & & & & & & & & $340-346$ & $\begin{array}{l}408.2396 \\
6328005\end{array}$ & $\begin{array}{l}814.46468 \\
12635864\end{array}$ & 814.5065 & -0.0419 & 0 R.ALLFVPR.R \\
\hline & & & & & & & & $\begin{array}{l}34 /-356 \\
348-356\end{array}$ & 554.7521 & $\begin{array}{l}11230.58641 \\
107.48961\end{array}$ & $\begin{array}{l}1260.6360 \\
1107.5349\end{array}$ & $\begin{array}{l}-0.0496 \\
-0.0452\end{array}$ & $\begin{array}{l}1 \text { R.RAPFDLFENR.K } \\
0 \text { R.APFDLFENR.K }\end{array}$ \\
\hline & & & & & & & & $388-401$ & 757.3570 & 1512.69941 & 1512.7784 & -0.0789 & 0 R.GVVDSEDLPLNISR.E \\
\hline & & & & & & & & $501-511$ & 618.2714 & 1234.52821 & 1234.5942 & -0.0660 & 0 K.DQVANSAFVER.L \\
\hline \multirow[t]{15}{*}{9} & P11499 & Heat shock protein HSP 90-beta & 83.2 & 488 & 18 & 4.97 & 23 & $\begin{array}{l}\text { Start - End } \\
42-55\end{array}$ & $\begin{array}{rl}\text { Observed } \\
515.5862 & 1:\end{array}$ & $\begin{array}{r}\text { Mr(expt) } \\
543.736815\end{array}$ & ) Mr(calc) & $\begin{array}{c}\text { Delta } \\
-0.0838\end{array}$ & $\begin{array}{l}\text { Miss Sequence } \\
1 \text { RELISNASDALDKIR.Y }\end{array}$ \\
\hline & & & & & & & & $73-82$ & 597.801011 & 193.587411 & 1193.6404 & -0.0530 & 0 K.IDILPNPQER.T \\
\hline & & & & & & & & $83-95$ & 675.344013 & 348.673413 & 1348.7272 & -0.0538 & 0 R.TLTLVDTGIGMTK.A \\
\hline & & & & & & & & $\begin{array}{c}83-95 \\
169-177\end{array}$ & 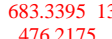 & 364.664413 & 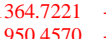 & -0.0577 & $\begin{array}{l}0 \text { R.TLTLVDTGIGMTK.A } \\
\text { O R R }\end{array}$ \\
\hline & & & & & & & & $181-196$ & 672.3232 & 2013.94782 & 2014.0371 & $\begin{array}{l}-0.0303 \\
-0.0893\end{array}$ & 1 K.VILHLKEDQTEYLEER.R \\
\hline & & & & & & & & $205-219$ & 603.6295 & 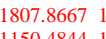 & 1807.9509 & -0.0842 & 0 K.HSQFIGYPITLYLEK.E \\
\hline & & & & & & & & $276-284$ & 576.2495 & 1150.48441 & 1150.5506 & -0.0661 & 0 K.YIDQEELNK.T \\
\hline & & & & & & & & $\begin{array}{l}276-284 \\
285-291\end{array}$ & $\begin{array}{l}576.2576 \\
451.2433\end{array}$ & $\begin{array}{l}1150.50061 \\
900.4720 \quad 9\end{array}$ & $\begin{array}{l}1150.5506 \\
900.5181\end{array}$ & $\begin{aligned} & -0.0499 \\
-0.0461 & \end{aligned}$ & $\begin{array}{l}0 \text { K.YIDQEELNK.T } \\
0 \text { K.TKPIWTR.N }\end{array}$ \\
\hline & & & & & & & & $292-306$ & $\begin{array}{l}452.4333 \\
92.3608\end{array}$ & 1846.70701 & 1846.7897 & $\begin{array}{l}-0.0401 \\
-0.0827\end{array}$ & 0 R.NPDDITQEEYGEFYK.S \\
\hline & & & & & & & & $338-347$ & 618.7966 & 1235.57861 & 1235.6299 & -0.0512 & 1 R.RAPFDLFENK.K \\
\hline & & & & & & & & $339-347$ & 540.7463 & 1079.47801 & 1079.5287 & -0.0507 & 0 R.APFDLFENK.K \\
\hline & & & & & & & & $379-392$ & 757.3570 & 1512.69941 & 1512.7784 & -0.0789 & 0 R.GVVDSEDLPLNISR.E \\
\hline & & & & & & & & $\begin{array}{l}429-435 \\
439-448\end{array}$ & $\begin{array}{l}446.1936 \\
571.2600\end{array}$ & $\begin{array}{l}890.37268 \\
1140.50541\end{array}$ & $\begin{array}{l}890.4174 \\
1140.5523\end{array}$ & $\begin{array}{c}-0.0448 \\
-0.0469\end{array}$ & $\begin{array}{l}\text { 0 K.FYEAFSK.N } \\
0 \text { K.LGIHEDSTNR.R }\end{array}$ \\
\hline & & & & & & & & $482-491$ & 580.7706 & 1159.52661 & 1159.5761 & -0.0494 & 0 K.SIYYITGESK.E \\
\hline & & & & & & & & $558-565$ & 505.2378 & 1008.46101 & 1008.5062 & -0.0452 & 1 K.AKFENLCK.L \\
\hline \multirow[t]{6}{*}{20} & P06151 & L-lactate dehydrogenase $A$ chain & 36,4 & 161 & 7 & 7.62 & 18 & Start - End & Observed & Mr(expt) & Mr(calc) & Delta & Miss Sequence \\
\hline & & & & & & & & $\begin{array}{l}82-90 \\
91-99\end{array}$ & $\begin{array}{rl}529.2570 & 1 \mathrm{c} \\
457.30669\end{array}$ & 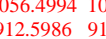 & $\begin{array}{l}1056.4546 \\
12.5756 \quad 0\end{array}$ & $\begin{array}{l}0.0448 \\
0.0230\end{array}$ & $\begin{array}{l}\text { 0 K.DYCVTANSK.L } \\
0 \text { K.LVIITAGAR.Q }\end{array}$ \\
\hline & & & & & & & & $158-169$ & 624.8273 & 1247.64001 & 1247.5928 & 0.0472 & 0 R.VIGSGCNLDSAR.F \\
\hline & & & & & & & & $233-243$ & 625.8594 & 1249.70421 & 1249.6554 & 0.0488 & 0 K.QVVDSAYEVIK.L \\
\hline & & & & & & & & $269-278$ & 399.8977 & 1196.67131 & 1196.6700 & 0.0013 & 1 R.RVHPISTMIK.G \\
\hline & & & & & & & & $\begin{array}{l}270-278 \\
306-315\end{array}$ & 521.3130 & 1040.61141 & 1040.5688 & 0.0426 & 0 R.VHPISTMIK.G \\
\hline \multirow{5}{*}{20} & P08249 & Malate dehydrogenase, & 35.5 & 136 & 5 & 8.93 & 15 & $\begin{array}{r}306-315 \\
\text { Start - End }\end{array}$ & $\begin{array}{l}572.8169 \\
\text { Observed }\end{array}$ & $\begin{array}{rl}1143.6192 & 1 \\
\mathbf{M r}(\text { expt })\end{array}$ & $\begin{array}{l}1143.5771 \\
\mathbf{M r}(\mathbf{c a l c})\end{array}$ & $\begin{array}{r}0.0421 \\
\text { Delta }\end{array}$ & $\begin{array}{l}\text { 0 K.VTLTPEEEAR.L } \\
\text { Miss Sequence }\end{array}$ \\
\hline & & mitar & & & & & & $\begin{array}{l}92-104 \\
166-176\end{array}$ & $\begin{array}{r}669.89041 \\
617.3821\end{array}$ & 1337.76621 & $\begin{array}{l}1337.7126 \\
1232.7129\end{array}$ & $\begin{array}{c}0.0537 \\
0.0368\end{array}$ & 0 K.GCDVVVIPAGVPR.K \\
\hline & & mitochondrial & & & & & & $177-185$ & 496.7875 & 991.56049 & $\begin{array}{l}123.21 / 29 \\
99338\end{array}$ & 0.0266 & $\begin{array}{l}0 \text { K.AFVTFVAELK.G } \\
0 \text { R.ANTFV }\end{array}$ \\
\hline & & & & & & & & $230-239$ & 537.3062 & 1072.59781 & 1072.5764 & 0.0214 & 0 R.IQEAGTEVVK.A \\
\hline & & & & & & & & $315-324$ & 565.8287 & 1129.64281 & 1129.6053 & 0.0376 & 0 K.MIAEAIPELK.A \\
\hline \multirow[t]{5}{*}{31} & P17751 & Triosephosphate isomerase & 26.6 & 121 & 5 & 6.90 & 20 & Start - End & $\begin{array}{c}\text { Observed } \\
5603124\end{array}$ & Mr(expt) & Mr(calc) & Delta & Miss Sequence \\
\hline & & & & & & & & $\begin{array}{c}60-69 \\
161-175\end{array}$ & $\begin{array}{r}569.312411 \\
801.9860\end{array}$ & $\begin{array}{l}136.610211 \\
1601.95741\end{array}$ & $\begin{array}{l}1136.5648 \\
1601.8817\end{array}$ & $\begin{array}{c}0.0454 \\
0.0757\end{array}$ & $\begin{array}{l}\text { 0 K.IAVAAQNCYK.V } \\
0 \text { K.VVLAYEPVWAIGTGK.T }\end{array}$ \\
\hline & & & & & & & & $161-175$ & 801.9883 & 1601.96201 & 1601.8817 & 0.0803 & 0 K.VVLAYEPVWAIGTGK.T \\
\hline & & & & & & & & $176-188$ & 489.6029 & 1465.78691 & 1465.7161 & 0.0708 & 0 K.TATPQQAQEVHEK.L \\
\hline & & & & & & & & & & & 1246.5902 & & \\
\hline
\end{tabular}




\section{References}

Aguzzi A. Molecular pathology of prion diseases. Vox Sang 2000; 78 Suppl 2: 25.

Aguzzi A, O'Connor T. Protein aggregation diseases: pathogenicity and therapeutic perspectives. Nat Rev Drug Discov 2010; 9: 237-248.

Anantharam V, Kanthasamy A, Choi CJ et al. Opposing roles of prion protein in oxidative stress- and ER stress-induced apoptotic signaling. Free Radic Biol Med 2008; 45: $1530-1541$.

Asif A, Yevzlin AS. Arterial stent placement in arteriovenous dialysis access by interventional nephrologists. Semin Dial 2009; 22: 557-560.

Asif AR, Armstrong VW, Voland A, Wieland E, Oellerich M, Shipkova M. Proteins identified as targets of the acyl glucuronide metabolite of mycophenolic acid in kidney tissue from mycophenolate mofetil treated rats. Biochimie 2007; 89: 393-402.

Bananis E, Murray JW, Stockert RJ, Satir P, Wolkoff AW. Microtubule and motordependent endocytic vesicle sorting in vitro. J Cell Biol 2000; 151: 179-186.

Bananis E, Nath S, Gordon K et al. Microtubule-dependent movement of late endocytic vesicles in vitro: requirements for Dynein and Kinesin. Mol Biol Cell 2004; 15: 36883697.

Barenco MG, Valori CF, Roncoroni C, Loewer J, Montrasio F, Rossi D. Deletion of the amino-terminal domain of the prion protein does not impair prion protein-dependent neuronal differentiation and neuritogenesis. J Neurosci Res 2009; 87: 806-819.

Ben-Zvi AP, Goloubinoff P. Review: mechanisms of disaggregation and refolding of stable protein aggregates by molecular chaperones. J Struct Biol 2001; 135: 84-93.

Benaud C, Gentil BJ, Assard N et al. AHNAK interaction with the annexin 2/S100A10 complex regulates cell membrane cytoarchitecture. J Cell Biol 2004; 164: 133-144.

Beringue V, Mallinson G, Kaisar M et al. Regional heterogeneity of cellular prion protein isoforms in the mouse brain. Brain 2003; 126: 2065-2073.

Borchelt DR, Taraboulos A, Prusiner SB. Evidence for synthesis of scrapie prion proteins in the endocytic pathway. J Biol Chem 1992; 267: 16188-16199.

Brandenburg LO, Lucius R, Tameh AA et al. Internalization and signal transduction of $\operatorname{PrP}(106-126)$ in neuronal cells. Ann Anat 2009; 191: 459-468.

Brandner S, Isenmann S, Raeber A et al. Normal host prion protein necessary for scrapie-induced neurotoxicity. Nature 1996; 379: 339-343.

Brown DR, Clive C, Haswell SJ. Antioxidant activity related to copper binding of native prion protein. J Neurochem 2001; 76: 69-76.

Brown DR, Qin K, Herms JW et al. The cellular prion protein binds copper in vivo. Nature 1997a; 390: 684-687. 
Brown DR, Schulz-Schaeffer WJ, Schmidt B, Kretzschmar HA. Prion protein-deficient cells show altered response to oxidative stress due to decreased SOD-1 activity. Exp Neurol 1997b; 146: 104-112.

Brown DR, Wong BS, Hafiz F, Clive C, Haswell SJ, Jones IM. Normal prion protein has an activity like that of superoxide dismutase. Biochem J 1999; 344 Pt 1: 1-5.

Brown HA, Gutowski S, Moomaw CR, Slaughter C, Sternweis PC. ADP-ribosylation factor, a small GTP-dependent regulatory protein, stimulates phospholipase $D$ activity. Cell 1993; 75: 1137-1144.

Bucci C, Thomsen P, Nicoziani P, McCarthy J, van DB. Rab7: a key to lysosome biogenesis. Mol Biol Cell 2000; 11: 467-480.

Bueler H, Aguzzi A, Sailer A et al. Mice devoid of PrP are resistant to scrapie. Cell 1993; 73: 1339-1347.

Capellari S, Zaidi SI, Urig CB, Perry G, Smith MA, Petersen RB. Prion protein glycosylation is sensitive to redox change. J Biol Chem 1999; 274: 34846-34850.

Caughey B. In vitro expression and biosynthesis of prion protein. Curr Top Microbiol Immunol 1991; 172: 93-107.

Caughey B, Baron GS. Prions and their partners in crime. Nature 2006; 443: 803-810.

Caughey B, Race R, Chesebro B. Comparative sequence analysis, in vitro expression and biosynthesis of mouse PrP. Prog Clin Biol Res 1989; 317: 619-636.

Caughey B, Raymond GJ. The scrapie-associated form of PrP is made from a cell surface precursor that is both protease- and phospholipase-sensitive. $J$ Biol Chem 1991; 266: 18217-18223.

Clarke AR, Jackson GS, Collinge J. The molecular biology of prion propagation. Philos Trans R Soc Lond B Biol Sci 2001; 356: 185-195.

Cockcroft S, Thomas GM, Fensome A et al. Phospholipase D: a downstream effector of ARF in granulocytes. Science 1994; 263: 523-526.

Collinge J, Whittington MA, Sidle KC et al. Prion protein is necessary for normal synaptic function. Nature 1994; 370: 295-297.

Cooper I, Malina KC, Cagnotto A, Bazzoni G, Salmona M, Teichberg VI. Interactions of the prion peptide (PrP 106-126) with brain capillary endothelial cells: coordinated cell killing and remodeling of intercellular junctions. J Neurochem 2010.

Cory AH, Owen TC, Barltrop JA, Cory JG. Use of an aqueous soluble tetrazolium/formazan assay for cell growth assays in culture. Cancer Commun 1991; 3: 207-212.

Daniel B, DeCoster MA. Quantification of SPLA2-induced early and late apoptosis changes in neuronal cell cultures using combined TUNEL and DAPI staining. Brain Res Brain Res Protoc 2004; 13: 144-150. 
DeArmond SJ, Kristensson K, Bowler RP. PrPSc causes nerve cell death and stimulates astrocyte proliferation: a paradox. Prog Brain Res 1992; 94: 437-446.

DeArmond SJ, Qiu Y, Sanchez H et al. PrPc glycoform heterogeneity as a function of brain region: implications for selective targeting of neurons by prion strains. J Neuropathol Exp Neurol 1999; 58: 1000-1009.

Donaldson JG. Arfs, phosphoinositides and membrane traffic. Biochem Soc Trans 2005; 33: 1276-1278.

Donaldson JG. Phospholipase D in endocytosis and endosomal recycling pathways. Biochim Biophys Acta 2009; 1791: 845-849.

Dong CF, Shi S, Wang XF et al. The N-terminus of PrP is responsible for interacting with tubulin and fCJD related PrP mutants possess stronger inhibitive effect on microtubule assembly in vitro. Arch Biochem Biophys 2008; 470: 83-92.

Edenhofer F, Rieger R, Famulok M, Wendler W, Weiss S, Winnacker EL. Prion protein PrPc interacts with molecular chaperones of the Hsp60 family. J Virol 1996; 70: 47244728.

Fensome-Green A, Cockcroft S. Reconstitution system based on cytosol-depleted cells to study the regulation of phospholipase D. Methods Mol Biol 2006; 332: 299-310.

Ferrer I. Synaptic pathology and cell death in the cerebellum in Creutzfeldt-Jakob disease. Cerebellum 2002; 1: 213-222.

Fletcher DA, Mullins RD. Cell mechanics and the cytoskeleton. Nature 2010; 463: 485492.

Fournier JG. Cellular prion protein electron microscopy: attempts/limits and clues to a synaptic trait. Implications in neurodegeneration process. Cell Tissue Res 2008; 332: 111.

Fournier JG, Escaig-Haye F, Billette d, V, Robain O. Ultrastructural localization of cellular prion protein (PrPc) in synaptic boutons of normal hamster hippocampus. C R Acad Sci III 1995; 318: 339-344.

Gauczynski S, Peyrin JM, Haik S et al. The 37-kDa/67-kDa laminin receptor acts as the cell-surface receptor for the cellular prion protein. EMBO J 2001; 20: 5863-5875.

Gilch S, Bach C, Lutzny G, Vorberg I, Schatzl HM. Inhibition of cholesterol recycling impairs cellular $\operatorname{PrP}(\mathrm{Sc})$ propagation. Cell Mol Life Sci 2009; 66: 3979-3991.

Giorgi A, Di FL, Principe S et al. Proteomic profiling of PrP27-30-enriched preparations extracted from the brain of hamsters with experimental scrapie. Proteomics 2009; 9: 3802-3814.

Goldmann W. PrP gene and its association with spongiform encephalopathies. Br Med Bull 1993; 49: 839-859. 
Gorodinsky A, Harris DA. Glycolipid-anchored proteins in neuroblastoma cells form detergent-resistant complexes without caveolin. J Cell Biol 1995; 129: 619-627.

Gorvel JP, Chavrier P, Zerial M, Gruenberg J. rab5 controls early endosome fusion in vitro. Cell 1991; 64: 915-925.

Graner E, Mercadante AF, Zanata SM et al. Cellular prion protein binds laminin and mediates neuritogenesis. Brain Res Mol Brain Res 2000; 76: 85-92.

Grant SG, O'Dell TJ, Karl KA, Stein PL, Soriano P, Kandel ER. Impaired long-term potentiation, spatial learning, and hippocampal development in fyn mutant mice. Science 1992; 258: 1903-1910.

Hachiya NS, Watanabe K, Sakasegawa Y, Kaneko K. Microtubules-associated intracellular localization of the $\mathrm{NH} 2$-terminal cellular prion protein fragment. Biochem Biophys Res Commun 2004a; 313: 818-823.

Hachiya NS, Watanabe K, Yamada M, Sakasegawa Y, Kaneko K. Anterograde and retrograde intracellular trafficking of fluorescent cellular prion protein. Biochem Biophys Res Commun 2004b; 315: 802-807.

Hajj GN, Lopes MH, Mercadante AF et al. Cellular prion protein interaction with vitronectin supports axonal growth and is compensated by integrins. J Cell Sci 2007; 120: $1915-1926$.

Haraguchi T, Fisher S, Olofsson S et al. Asparagine-linked glycosylation of the scrapie and cellular prion proteins. Arch Biochem Biophys 1989; 274: 1-13.

Harris DA. Cell biological studies of the prion protein. Curr Issues Mol Biol 1999; 1: 6575.

Harris DA. Trafficking, turnover and membrane topology of PrP. Br Med Bull 2003; 66: 71-85.

Hehnly H, Xu W, Chen JL, Stamnes M. Cdc42 regulates microtubule-dependent Golgi positioning. Traffic 2010; 11: 1067-1078.

Henle KJ, Jethmalani SM, Nagle WA. Stress proteins and glycoproteins (Review). Int J Mol Med 1998; 1: 25-32.

Herms J, Tings T, Gall S et al. Evidence of presynaptic location and function of the prion protein. J Neurosci 1999; 19: 8866-8875.

Honda A, Nogami M, Yokozeki T et al. Phosphatidylinositol 4-phosphate 5-kinase alpha is a downstream effector of the small G protein ARF6 in membrane ruffle formation. Cell 1999; 99: 521-532.

Hsich G, Kenney K, Gibbs CJ, Lee KH, Harrington MG. The 14-3-3 brain protein in cerebrospinal fluid as a marker for transmissible spongiform encephalopathies. $\mathrm{N}$ Engl $\mathrm{J}$ Med 1996; 335: 924-930. 
Jang B, Kim E, Choi JK et al. Accumulation of citrullinated proteins by up-regulated peptidylarginine deiminase 2 in brains of scrapie-infected mice: a possible role in pathogenesis. Am J Pathol 2008; 173: 1129-1142.

Jeffrey M, Goodsir CM, Fowler N, Hope J, Bruce ME, McBride PA. Ultrastructural immuno-localization of synthetic prion protein peptide antibodies in $87 \mathrm{~V}$ murine scrapie. Neurodegeneration 1996; 5: 101-109.

Jeffrey M, Halliday WG, Bell $\mathrm{J}$ et al. Synapse loss associated with abnormal PrP precedes neuronal degeneration in the scrapie-infected murine hippocampus. Neuropathol Appl Neurobiol 2000; 26: 41-54.

Jin $\mathrm{T}, \mathrm{Gu} \mathrm{Y}$, Zanusso $\mathrm{G}$ et al. The chaperone protein BiP binds to a mutant prion protein and mediates its degradation by the proteasome. J Biol Chem 2000; 275: 38699-38704.

Johnston AR, Black C, Fraser J, MacLeod N. Scrapie infection alters the membrane and synaptic properties of mouse hippocampal CA1 pyramidal neurones. J Physiol 1997; 500 ( Pt 1): 1-15.

Junttila MR, Saarinen S, Schmidt T, Kast J, Westermarck J. Single-step Strep-tag purification for the isolation and identification of protein complexes from mammalian cells. Proteomics 2005; 5: 1199-1203.

Kaiser C, Ferro-Novick S. Transport from the endoplasmic reticulum to the Golgi. Curr Opin Cell Biol 1998; 10: 477-482.

Kanaani J, Prusiner SB, Diacovo J, Baekkeskov S, Legname G. Recombinant prion protein induces rapid polarization and development of synapses in embryonic rat hippocampal neurons in vitro. J Neurochem 2005; 95: 1373-1386.

Keshava Prasad TS, Goel R, Kandasamy K et al. Human Protein Reference Database-2009 update. Nucleic Acids Res 2009; 37: D767-D772.

Knight RS, Will RG. Prion diseases. J Neurol Neurosurg Psychiatry 2004; 75 Suppl 1: i36-i42.

Korte S, Vassallo N, Kramer ML, Kretzschmar HA, Herms J. Modulation of L-type voltage-gated calcium channels by recombinant prion protein. J Neurochem 2003; 87: 1037-1042.

Kosako H, Goto H, Yanagida $\mathrm{M}$ et al. Specific accumulation of Rho-associated kinase at the cleavage furrow during cytokinesis: cleavage furrow-specific phosphorylation of intermediate filaments. Oncogene 1999; 18: 2783-2788.

Kretzschmar HA, Tings T, Madlung A, Giese A, Herms J. Function of $\operatorname{PrP}(\mathrm{C})$ as a copper-binding protein at the synapse. Arch Virol Suppl 2000; 239-249.

Kurschner C, Morgan Jl. The cellular prion protein (PrP) selectively binds to $\mathrm{Bcl}-2$ in the yeast two-hybrid system. Brain Res Mol Brain Res 1995; 30: 165-168. 
Kurschner C, Morgan Jl. Analysis of interaction sites in homo- and heteromeric complexes containing Bcl-2 family members and the cellular prion protein. Brain Res Mol Brain Res 1996; 37: 249-258.

Lasmezas Cl. Putative functions of $\operatorname{PrP}(\mathrm{C})$. Br Med Bull 2003; 66: 61-70.

Lawson VA, Collins SJ, Masters CL, Hill AF. Prion protein glycosylation. J Neurochem 2005; 93: 793-801.

Lee $\mathrm{S}$, Antony L, Hartmann $\mathrm{R}$ et al. Conformational diversity in prion protein variants influences intermolecular beta-sheet formation. EMBO J 2010; 29: 251-262.

Legname G, Baskakov IV, Nguyen $\mathrm{HO}$ et al. Synthetic mammalian prions. Science 2004; 305: 673-676.

Lima FR, Arantes CP, Muras AG, Nomizo R, Brentani RR, Martins VR. Cellular prion protein expression in astrocytes modulates neuronal survival and differentiation. $J$ Neurochem 2007; 103: 2164-2176.

Linden R, Martins VR, Prado MA, Cammarota M, Izquierdo I, Brentani RR. Physiology of the prion protein. Physiol Rev 2008; 88: 673-728.

Liu GP, Wei W, Zhou X et al. I(2)(PP2A) regulates p53 and Akt correlatively and leads the neurons to abort apoptosis. Neurobiol Aging 2010.

Lodish HF. Molecular cell biology. 2004; 5th ed.

Lopez CD, Yost CS, Prusiner SB, Myers RM, Lingappa VR. Unusual topogenic sequence directs prion protein biogenesis. Science 1990; 248: 226-229.

Ma J, Lindquist S. Wild-type PrP and a mutant associated with prion disease are subject to retrograde transport and proteasome degradation. Proc Natl Acad Sci U S A 2001; 98: $14955-14960$.

Magalhaes AC, Silva JA, Lee KS et al. Endocytic intermediates involved with the intracellular trafficking of a fluorescent cellular prion protein. J Biol Chem 2002; 277: 33311-33318.

Malaga-Trillo E, Solis GP, Schrock Y et al. Regulation of embryonic cell adhesion by the prion protein. PLoS Biol 2009; 7: e55.

Mallik S, Yang W, Norstrom EM, Mastrianni JA. Live cell fluorescence resonance energy transfer predicts an altered molecular association of heterologous PrPSc with PrPC. J Biol Chem 2010; 285: 8967-8975.

Markgraf DF, Peplowska K, Ungermann C. Rab cascades and tethering factors in the endomembrane system. FEBS Lett 2007; 581: 2125-2130.

Matteoni R, Kreis TE. Translocation and clustering of endosomes and lysosomes depends on microtubules. J Cell Biol 1987; 105: 1253-1265. 
McKinley MP, Bolton DC, Prusiner SB. A protease-resistant protein is a structural component of the scrapie prion. Cell 1983; 35: 57-62.

McMurray CT. Neurodegeneration: diseases of the cytoskeleton? Cell Death Differ 2000; 7: 861-865.

Mei GY, Li Y, Wang GR et al. [Molecular interaction between PrP protein and the signal protein 14-3-3 beta]. Bing Du Xue Bao 2009; 25: 208-212.

Morel E, Fouquet S, Strup-Perrot $\mathrm{C}$ et al. The cellular prion protein $\operatorname{PrP}(\mathrm{c})$ is involved in the proliferation of epithelial cells and in the distribution of junction-associated proteins. PLoS One 2008; 3: e3000.

Morot-Gaudry-Talarmain Y, Rezaei H, Guermonprez L, Treguer E, Grosclaude J. Selective prion protein binding to synaptic components is modulated by oxidative and nitrosative changes induced by copper(II) and peroxynitrite in cholinergic synaptosomes, unveiling a role for calcineurin B and thioredoxin. J Neurochem 2003; 87: $1456-1470$.

Morrison HA, Dionne H, Rusten TE et al. Regulation of early endosomal entry by the Drosophila tumor suppressors Rabenosyn and Vps45. Mol Biol Cell 2008; 19: 41674176.

Mouillet-Richard S, Ermonval M, Chebassier $\mathrm{C}$ et al. Signal transduction through prion protein. Science 2000; 289: 1925-1928.

Mouillet-Richard S, Laurendeau I, Vidaud M, Kellermann O, Laplanche JL. Prion protein and neuronal differentiation: quantitative analysis of prnp gene expression in a murine inducible neuroectodermal progenitor. Microbes Infect 1999; 1: 969-976.

Muslin AJ. Road Rage: Cardiac Rab1 and ER-to-Golgi Traffic. Circ Res 2001; 89: 10871088.

Naslavsky N, Stein R, Yanai A, Friedlander G, Taraboulos A. Characterization of detergent-insoluble complexes containing the cellular prion protein and its scrapie isoform. J Biol Chem 1997; 272: 6324-6331.

Nielsen E, Cheung AY, Ueda T. The regulatory RAB and ARF GTPases for vesicular trafficking. Plant Physiol 2008; 147: 1516-1526.

Nielsen E, Severin F, Backer JM, Hyman AA, Zerial M. Rab5 regulates motility of early endosomes on microtubules. Nat Cell Biol 1999; 1: 376-382.

Nielsen E, Severin F, Hyman AA, Zerial M. In vitro reconstitution of endosome motility along microtubules. Methods Mol Biol 2001; 164: 133-146.

Nieznanski K. Interactions of Prion Protein With Intracellular Proteins: So Many Partners and no Consequences? Cell Mol Neurobiol 2009. 
Nieznanski K, Nieznanska H, Skowronek KJ, Osiecka KM, Stepkowski D. Direct interaction between prion protein and tubulin. Biochem Biophys Res Commun 2005; 334: 403-411.

Oakley AJ. Glutathione transferases: new functions. Curr Opin Struct Biol 2005; 15: 716-723.

Oesch B, Teplow DB, Stahl N, Serban D, Hood LE, Prusiner SB. Identification of cellular proteins binding to the scrapie prion protein. Biochemistry 1990; 29: 5848-5855.

Pan T, Wong BS, Liu T, Li R, Petersen RB, Sy MS. Cell-surface prion protein interacts with glycosaminoglycans. Biochem J 2002; 368: 81-90.

Paruch S, El-Benna J, Djerdjouri B, Marullo S, Perianin A. A role of p44/42 mitogenactivated protein kinases in formyl-peptide receptor-mediated phospholipase $D$ activity and oxidant production. FASEB J 2006; 20: 142-144.

Priola SA, Caughey B. Inhibition of scrapie-associated PrP accumulation. Probing the role of glycosaminoglycans in amyloidogenesis. Mol Neurobiol 1994; 8: 113-120.

Prusiner SB. Prions. Proc Natl Acad Sci U S A 1998a; 95: 13363-13383.

Prusiner SB. The prion diseases. Brain Pathol 1998b; 8: 499-513.

Puxeddu E, Uhart M, Li CC et al. Interaction of phosphodiesterase 3A with brefeldin Ainhibited guanine nucleotide-exchange proteins BIG1 and BIG2 and effect on ARF1 activity. Proc Natl Acad Sci U S A 2009; 106: 6158-6163.

Rachidi W, Mange A, Senator A et al. Prion infection impairs copper binding of cultured cells. J Biol Chem 2003; 278: 14595-14598.

Ramljak S, Asif AR, Armstrong VW et al. Physiological role of the cellular prion protein (PrPc): protein profiling study in two cell culture systems. J Proteome Res 2008; 7: 2681-2695.

$\mathrm{Re} \mathrm{L}$, Rossini $\mathrm{F}, \mathrm{Re} \mathrm{F}$ et al. Prion protein potentiates acetylcholine release at the neuromuscular junction. Pharmacol Res 2006; 53: 62-68.

Rieger R, Edenhofer F, Lasmezas Cl, Weiss S. The human 37-kDa laminin receptor precursor interacts with the prion protein in eukaryotic cells. Nat Med 1997; 3: 13831388.

Riek R, Hornemann S, Wider G, Glockshuber R, Wuthrich K. NMR characterization of the full-length recombinant murine prion protein, $\operatorname{mPrP}(23-231)$. FEBS Lett 1997; 413: 282-288.

Rothman JE. The protein machinery of vesicle budding and fusion. Protein Sci 1996; 5: 185-194.

Roucou X, LeBlanc AC. Cellular prion protein neuroprotective function: implications in prion diseases. J Mol Med 2005; 83: 3-11. 
Rudd PM, Endo T, Colominas $\mathrm{C}$ et al. Glycosylation differences between the normal and pathogenic prion protein isoforms. Proc Natl Acad Sci U S A 1999; 96: 1304413049.

Rudd PM, Merry AH, Wormald MR, Dwek RA. Glycosylation and prion protein. Curr Opin Struct Biol 2002; 12: 578-586.

Russell MR, Nickerson DP, Odorizzi G. Molecular mechanisms of late endosome morphology, identity and sorting. Curr Opin Cell Biol 2006; 18: 422-428.

Sakudo A, Ikuta K. Fundamentals of prion diseases and their involvement in the loss of function of cellular prion protein. Protein Pept Lett 2009; 16: 217-229.

Sakudo A, Lee DC, Nishimura T et al. Octapeptide repeat region and N-terminal half of hydrophobic region of prion protein (PrP) mediate PrP-dependent activation of superoxide dismutase. Biochem Biophys Res Commun 2005; 326: 600-606.

Santuccione A, Sytnyk V, Leshchyns'ka I, Schachner M. Prion protein recruits its neuronal receptor NCAM to lipid rafts to activate p59fyn and to enhance neurite outgrowth. J Cell Biol 2005; 169: 341-354.

Satoh $\mathrm{H}$, Yamato $\mathrm{O}$, Asano $\mathrm{T}$ et al. Cerebrospinal fluid biomarkers showing neurodegeneration in dogs with GM1 gangliosidosis: possible use for assessment of a therapeutic regimen. Brain Res 2007; 1133: 200-208.

Satoh J, Onoue H, Arima K, Yamamura T. The 14-3-3 protein forms a molecular complex with heat shock protein Hsp60 and cellular prion protein. J Neuropathol Exp Neurol 2005; 64: 858-868.

Schmidt $\mathrm{H}$, Otto $\mathrm{M}$, Niedmann $\mathrm{P}$ et al. CSF lactate dehydrogenase activity in patients with Creutzfeldt-Jakob disease exceeds that in other dementias. Dement Geriatr Cogn Disord 2004; 17: 204-206.

Schimmoller F, Simon I, Pfeffer SR. Rab GTPases, directors of vesicle docking. J Biol Chem 1998; 273: 22161-22164.

Schmoranzer J, Simon SM. Role of microtubules in fusion of post-Golgi vesicles to the plasma membrane. Mol Biol Cell 2003; 14: 1558-1569.

Schmitt-Ulms G, Legname G, Baldwin MA et al. Binding of neural cell adhesion molecules (N-CAMs) to the cellular prion protein. J Mol Biol 2001; 314: 1209-1225.

Shyng SL, Huber MT, Harris DA. A prion protein cycles between the cell surface and an endocytic compartment in cultured neuroblastoma cells. J Biol Chem 1993; 268: 15922 15928.

Sideri TC, Stojanovski K, Tuite MF, Grant CM. Ribosome-associated peroxiredoxins suppress oxidative stress-induced de novo formation of the [PSI+] prion in yeast. Proc Natl Acad Sci U S A 2010; 107: 6394-6399.

Spielhaupter C, Schatzl HM. PrPC directly interacts with proteins involved in signaling pathways. J Biol Chem 2001; 276: 44604-44612. 
Spisni E, Valerii MC, Manerba M et al. Effect of copper on extracellular levels of key pro-inflammatory molecules in hypothalamic GN11 and primary neurons. Neurotoxicology 2009; 30: 605-612.

Stahl N, Borchelt DR, Hsiao K, Prusiner SB. Scrapie prion protein contains a phosphatidylinositol glycolipid. Cell 1987; 51: 229-240.

Steele AD, Emsley JG, Ozdinler PH, Lindquist S, Macklis JD. Prion protein (PrPc) positively regulates neural precursor proliferation during developmental and adult mammalian neurogenesis. Proc Natl Acad Sci U S A 2006; 103: 3416-3421.

Toni M, Massimino ML, Griffoni C, Salvato B, Tomasi V, Spisni E. Extracellular copper ions regulate cellular prion protein (PrPC) expression and metabolism in neuronal cells. FEBS Lett 2005; 579: 741-744.

Turk E, Teplow DB, Hood LE, Prusiner SB. Purification and properties of the cellular and scrapie hamster prion proteins. Eur J Biochem 1988; 176: 21-30.

Turu M, Slevin M, Ethirajan $\mathrm{P}$ et al. The normal cellular prion protein and its possible role in angiogenesis. Front Biosci 2008; 13: 6491-6500.

Vanlandingham PA, Ceresa BP. Rab7 Regulates Late Endocytic Trafficking Downstream of Multivesicular Body Biogenesis and Cargo Sequestration. Journal of Biological Chemistry 2009; 284: 12110-12124.

Varela-Nallar L, Toledo EM, Chacon MA, Inestrosa NC. The functional links between prion protein and copper. Biol Res 2006; 39: 39-44.

Volpicelli-Daley LA, Li Y, Zhang CJ, Kahn RA. Isoform-selective effects of the depletion of ADP-ribosylation factors 1-5 on membrane traffic. Mol Biol Cell 2005; 16: 4495-4508.

Vonderheit A, Helenius A. Rab7 associates with early endosomes to mediate sorting and transport of Semliki forest virus to late endosomes. PLoS Biol 2005; 3: e233.

Watts JC, Huo $\mathrm{H}$, Bai $\mathrm{Y}$ et al. Interactome analyses identify ties of PrP and its mammalian paralogs to oligomannosidic $\mathrm{N}$-glycans and endoplasmic reticulum-derived chaperones. PLoS Pathog 2009; 5: e1000608.

Weis WI, Scheller RH. Membrane fusion. SNARE the rod, coil the complex. Nature 1998; 395: 328-329.

Wessel D, Flugge UI. A method for the quantitative recovery of protein in dilute solution in the presence of detergents and lipids. Anal Biochem 1984; 138: 141-143.

Westergard L, Christensen HM, Harris DA. The cellular prion protein $(\operatorname{PrP}(C))$ : its physiological function and role in disease. Biochim Biophys Acta 2007; 1772: 629-644.

Wu G, Nakajima K, Takeyama N et al. Species-specific anti-apoptotic activity of cellular prion protein in a mouse PrP-deficient neuronal cell line transfected with mouse, hamster, and bovine Prnp. Neurosci Lett 2008; 446: 11-15. 
Wunderlich W, Fialka I, Teis D et al. A novel 14-kilodalton protein interacts with the mitogen-activated protein kinase scaffold $\mathrm{mp} 1$ on a late endosomal/lysosomal compartment. J Cell Biol 2001; 152: 765-776.

Yedidia Y, Horonchik L, Tzaban S, Yanai A, Taraboulos A. Proteasomes and ubiquitin are involved in the turnover of the wild-type prion protein. EMBO J 2001; 20: 5383-5391.

Yoo BC, Krapfenbauer K, Cairns N, Belay G, Bajo M, Lubec G. Overexpressed protein disulfide isomerase in brains of patients with sporadic Creutzfeldt-Jakob disease. Neurosci Lett 2002; 334: 196-200.

Zanata SM, Lopes $\mathrm{MH}$, Mercadante AF et al. Stress-inducible protein 1 is a cell surface ligand for cellular prion that triggers neuroprotection. EMBO J 2002; 21: 3307-3316.

Zerial M, McBride H. Rab proteins as membrane organizers. Nat Rev Mol Cell Biol 2001; 2: 107-117. 


\section{Publications}

Zafar, S., von, A. N., Oellerich, M., Zerr, I., Schulz-Schaeffer, W. J., Armstrong, V. W., and Asif, A. R. (2011) Proteomics Approach to Identify the Interacting Partners of Cellular Prion Protein and Characterization of Rab7a Interaction in Neuronal Cells. J. Proteome. Res.

\section{Abstracts/Posters Published}

Zafar S, Asif AR., Armstrong VW, Oellerich M, One-C-Terminus One-STrEP-tagged human prion protein expression, purification, localization and identification of interacting proteins in mammalian cell line, Clinical Chemistry and Laboratory Medicine, 2008; 46(9):A175.

Zafar S, Asif AR., Armstrong VW, Oellerich M, Human cellular prion protein ( $\left.\operatorname{PrP}^{\mathrm{C}}\right)$ : Distribution and co-localization with early endosome in a neuronal cell line, Clinical Chemistry and Laboratory Medicine, 2009; 47(9):A63.

Zafar S, Asif AR., Armstrong VW, Oellerich M, Molecular interaction of human Prion protein and cytoskeleton associated proteins. International conference of 'Prion' Thessaloniki-Chalkidiki, Greece, 2009.

Zafar S, Ahsen NV, Oellerich M, Schulz-Schaeffer WJ, Armstrong VW, Asif AR, Human cellular prion protein $\left(\mathrm{PrP}^{\mathrm{C}}\right)$ : Human Cellular Prion Protein $\left(\operatorname{PrP}^{\mathrm{C}}\right)$ : Identification of Novel Interacting Partners \& Characterization in association with endosome and microtubules. 2010. 


\section{Acknowledgements}

I bow my head in gratitude to "Almighty Allah", whose blessings and exaltation flourished my thoughts, which enabled me to accomplish this task. Countless thanks to Allah, the Beneficent and the Merciful, from the depth of my heart. He is the One Who always takes troubles away from me and blessed me with courage and strength. Blessings and salutation on "Hazrat Muhammad (PBUH)", who is forever a torch of knowledge and tower of guidance for me.

My special gratitude to the Late Prof. Dr. Victor W. Armstrong for an interesting project, constant encouragement, affection, care and support until the last moment of his life (May his soul rest in peace amen). I owe very special thanks to Prof. M. Oellerich, director of the department of Clinical Chemistry, UMG, for his cooperation and for providing me privileges in this department. I would like to thank Dr. A. R. Asif and Prof. Nicolas von Ahsen who facilitated my work.

My very special thanks to Prof. Philip D. Walson (Visiting Professor, Dept of Laboratory Medicine, UMG) for his time and his critical review of my thesis.

I express my particular gratitude to my scientific supervisors, Prof. Dr. Uwe Groß and Prof. Dr. Nils Brose, for their outstanding supervision, support and contribution to my success. Their constructive criticism and suggestions are highly appreciated.

My sincere thanks to Dr. Nadeem Sheikh for his care, valuable guidance, skilled advice and moral support over the last 10 years and I wish to continue to have this eternally.

My special thanks to Dr. Ihtzaz Ahmed Malik who picked me up from the Frankfurt airport and dropped me off in Goettingen to start my new life as a Doctoral student. He helped, bore and supported me from the very first day in Germany until today to make me fly in colors. Thanks for being there when I needed you the most. I also would like to say thanks to Dr. Ahmed Shariq for his encouragement during my PhD work.

I am thankful to Dr. Hassen Dihazi and Dr. Matthius Schmitz for providing me antibodies. I am also thankful to Dr. Inga Zerr, Joanna Gawinecka, Dr. Christina Behrman and Dr. Sanja Ramaljak for their time discussing prion protein.

For technical support and an enjoyable working atmosphere, I wish to thank both past and present members from the institute: Christa, Christina, Darinka, Frank, Hazir, Misbah, Qasim, Reiner, Sandra and Suzana. I would also like to thank all of my friends back in Pakistan and here who shared the ups and downs during my stay in Germany. I am craving to say thanks to Naila, Sadia and Sadaf to be with me to accomplish my brainless adventures.

Finally, I would like to thank my family back home, my sisters Shaista and Huma, my brother Najam and Amma Aba, for their undaunting perseverance and support all this time that I have been away from them in the pursuit of my goal.

Thanks.

Saima 


\section{Curriculum vitae}

Family Name

First name

Date of birth

Place of birth

Citizenship

\section{Education}

2007- 2010

2005-2007

$2003-2005$

$2000-2003$

$1998-2000$
Zafar

Saima

16.12.1982

Lahore, Pakistan

Pakistani

\section{PhD in biology}

Department of Clinical Chemistry,

University Medical Center,

Georg-August University, Goettingen

Title: "Cellular Prion Protein: Identification and Characterization of Novel Interacting Partners".

Master of Philosophy (M.Phil.) in Molecular Biology

Center of Excellence in Molecular Biology,

University of the Punjab, Lahore, Pakistan

Title: "Effect of Small Interfering RNA against the p7 Gene of Hepatitis C Virus Genotype 1a".

Master of Science in Zoology

Gold Medal, Role of Honor

University of the Punjab, Lahore, Pakistan

Bachelors of Science (Hons.) in Zoology

Gold Medal, Role of Honor

University of the Punjab, Lahore, Pakistan

College Education

Multan, Pakistan. 